\title{
PÍLDORAS EN SU LABERINTO
}

\section{PILLS IN THE MAZE}

Carlos Gamero Esparza: Universidad Inca Garcilaso de la Vega (Perú). carlos.gamero@ozu.es

\section{CURRÍCULUM VITAE}

Reconocido Periodista peruano. Licenciado con Diploma de Honor en la Universidad Inca Garcilaso de la Vega.

\section{RESUMEN}

La talidomida, la llamada droga milagrosa, sigue existiendo entre nosotros. Cuarenta años después de la tragedia de los niños con malformaciones congénitas, aún hay muchas preguntas sin responder. Aunque se indicó que dicha sustancia se podía emplear únicamente en el tratamiento de otras enfermedades como la lepra y algunos cánceres, aún son muchos los países en los que las autoridades sanitarias no tienen registrada la talidomida como sustancia química peligrosa en sus bases de datos, y donde se hace poco o nada para prevenir a la población del mal uso de esta sustancia teratógena, es decir, un fármaco capaz de provocar malformaciones congénitas. Este trabajo es un homenaje a aquellos hombres y mujeres, víctimas de la droga maldita, pero también una advertencia contra la irresponsabilidad y la negligencia de malos empresarios, contra la desidia de los gobiernos, contra lo que no debió suceder jamás. 


\title{
PALABRAS CLAVE
}

Talidomida - Niños - Malformaciones congénitas - Enfermedad

\begin{abstract}
Thalidomide, the so-called miracle drug, continues to exist between us. Forty years after the tragedy of children with congenital malformations, there are still many unanswered questions. Although it was indicated that this substance could only be used in the treatment of other diseases such as leprosy and some cancers, there are still many countries where health authorities have not registered thalidomide as hazardous chemical in their databases, and where little or nothing to prevent people from misuse of this substance teratogenic, ie, a drug capable of causing birth defects. This work is a tribute to those men and women, victims of drug cursed, but also a warning against irresponsibility and bad business negligence, against the apathy of governments, against what should not ever happen.
\end{abstract}

\section{KEY WORDS}

Thalidomide - Children - Congenital malformations - Illness

\section{ÍNDICE}

1. Introducción

2. La desdichada saga del Contergan

2.1. "Especialmente conveniente para el embarazo"

2.2. No, pero sí...

2.3. Pesadilla farmacológica

2.4. Mujeres al borde de un ataque de nervios 
3. Las tribulaciones del Kevadon I

3.1. Una heroína en el gabinete

3.2. Papelito manda...

4. Las tribulaciones del Kevadon II

4.1. Una fábrica Merrell desconcertada...

4.2. El desaliento tardío

5. Alarma en el Sur...

6. La talidomida en el Perú

6.1. La incongruencia del CENAFIM

6.2. ¿Quién explica este desaguisado?

7. La crisis en el país más seguro del mundo...

8. Las víctimas "oficiales" y las otras...

9. La otra historia

9.1. La OMS, el mejor cliente de Chemie-Grünenthal

9.2. ¿Hubo o hay niños víctimas de la talidomida en la selva peruana?

10. Los niños del Brasil

10.1. La embriopatía que llegó del frío

10.2. Chicos en crisis

10.3. La lepra, una buena excusa

10.4. Los débiles argumentos de la OMS

10.5. ¿Provocando un nuevo desastre?

11. La droga omnipresente

11.1. Las muchas caras de la talidomida

12. Los motivos del FDA

12.1. La primera de una segunda vez

12.2. S.T.E.P.S., los bebés primero

12.3. Promesa... y alerta para el futuro

13. ¿Qué es la focomelia talidomídica?

14. ¿La talidomida afecta el código genético? 
15. Talidomida clandestina

15.1. Los entretelones de un mercado siniestro

15.2. El uso de la Talidomida crece oculta e ilegalmente

15.3. Vía de acceso a los "Clubes de Compradores"

15.4. ¿Ausencia de efectos secundarios?

16. ¿Sabía usted que...?

17. La píldora del ayer ha forjado héroes (y heroínas) del hoy

17.1. Un libro contra la talidomida

17.1.1. Una crónica murciana...

17.2. Beatriz de Gran Canaria

17.3. Un alcalde en Teruel

17.4. La vida de Tom es un arte

17.5. Un chico de pelo rubio y famoso

17.6. ¡Qué no hacen los japoneses!

17.7. Con los pies canta mi guitarra...

18. Epílogo I: Desde Murcia, habla José Riquelme

19. Epílogo II: La "talidomida" un riesgo monstruoso

20. Epílogo III: Noticia de última hora... ¿Se retracta la doctora Vásquez?

21. Para saber más...

22. APÉNDICE: Lo que dice el fabricante (Chemie-Grünenthal)

22.1. Talidomida 1957 (I)

22.2. La talidomida 1957 (II)

23. Bibliografía 


\section{TEXTO:}

\section{Introducción}

40 años después de la tragedia de los niños con malformaciones congénitas, y a cuatro de la discutida aprobación por parte de la FDA estadounidense de la comercialización de la talidomida, aún muchas preguntas sobre su porqué siguen sin respuestas. Aunque se indicó en su momento que ésta vez se trataba de utilizar dicha sustancia para el tratamiento de otras enfermedades como la lepra y algunos cánceres, lo cierto es que inquieta el silencio solapado de las autoridades sanitarias de muchos de nuestros países, algunos de los cuales al parecer no tienen registrada la talidomida como sustancia química peligrosa en sus bases de datos, como es el caso peruano, donde se hizo poco o nada para prevenir a la población sobre los peligros de un mal consumo de esta sustancia teratógena (esto es, un fármaco capaz de provocar malformaciones congénitas) en sus diferentes variantes, al poco tiempo de haber sido aprobada en Estados Unidos.

Tal como se desprende de las investigaciones realizadas sobre la entonces llamada "droga milagrosa", que devino en terrible pesadilla, la talidomida no solo causó entre diez mil y quince mil bebés deformados en todo el mundo (hay quienes hablan de 20 mil y más), sino que algunas de sus diferentes presentaciones comerciales continuaron vigentes en Latinoamérica y otras latitudes, aún después de que éstas fueran prohibidas en 1965. Con la anuencia de no sabemos qué ocultos intereses, y la permisividad de organizaciones internacionales como la OMS (como veremos luego, se trata de una insólita contradicción), esta sustancia -ya fuera de circulación en el mal llamado primer mundo - siguió causando estragos en lugares tan remotos como las selvas amazónicas peruana y brasileña, tal como se verá en este informe. 
La aprobación oficial de la talidomida en 1998 fue ciertamente objeto de algunas suspicacias y protestas, pero también de la apatía por parte de gobiernos y responsables de la seguridad sanitaria en América Latina -como ya se dijo arriba -; este es, por ejemplo, el caso peruano, donde tanto el Ministerio de Salud, como ente responsable de la Sanidad Nacional, como el DIGEMID, organismo público supuestamente encargado del control de cuanto fármaco se expenda en nuestras farmacias, en su torpe burocracia, han insistido que tal principio activo -la talidomida - no figura en sus bases de datos (¿?)... y que sólo tienen registros de fármacos y sustancias químicas ¡desde 1987!, pese a que la misma figura como sustancia peligrosa en las listas de la OMS y su filial, la OPS. Mientras tanto, el silencio de las víctimas -y su infinita desesperanza - no encuentran justicia, menos consuelo. Y esto no sólo se ve en el Perú... la mascarada de la indiferencia fingida parece ser el común denominador de un mal congénito en una sociedad realmente inhumana.

Fue atroz para quien esto escribe ver el dolor y la impotencia marcados en la mirada de aquellos seres humanos, algunos sin brazos, otros sin piernas, los demás en un estado tan lamentable de carencias físicas, cuando no emocionales; pero más doloroso es ver el silencio cómplice y la indolencia, como si estas víctimas de la talidomida nunca hubieran existido. ¡Allí estaban ellos, consumidos en su minusvalía provocada por la irresponsable absurdez humana! Sin embargo, contra aquella maldad que se cometió contra sus vidas -que más cruel ha sido la respuesta de la sociedad ante su minusvalía que la propia malformación causada por la droga-, muchos de aquellos hijos de la talidomida supieron levantarse contra el infortunio y triunfar en un mundo espinoso!... y convirtieron su tragedia en un canto a la vida.

Para ellos y por ellos, a la gloria de su lucha y su canción, va dedicado este esfuerzo editorial que no ha sido fácil y ha tardado años. Este trabajo es un homenaje a aquellos hombres y mujeres, víctimas de la droga maldita, pero también una 
advertencia contra la irresponsabilidad y la negligencia de malos empresarios, contra la desidia de los gobiernos, contra lo que no debió suceder jamás; y una lección para quienes se embarcan en el negocio de la industria farmacéutica: elaborar medicamentos de consumo masivo con sustancias químicas de riesgo no es cosa de niños. Como lo es la historia que sigue...

\section{La desdichada saga del Contergan}

\subsection{Especialmente conveniente para el embarazo}

Todo comenzó en 1953, cuando el doctor Wilhem Kunz (2) sintetizó en los laboratorios Chemie-Grünenthal (3), en la entonces República Federal de Alemania, una sustancia química a la que denominó thalidomide, palabra compuesta derivada de N-phthaloylglutamide o amida de ácido italiglutámico, durante un programa de desarrollo de drogas antihistamínicas para el tratamiento de las alergias, pero al encontrarse que no era muy efectiva en este campo, se determinó que tenía un efecto hipnótico y sedante.

A pesar de las pocas perspectivas que se le avizoraba a este compuesto químico, en octubre de 1957 los laboratorios Chemie-Grünenthal, sin mayor trámite, y con apenas dos años de ensayos clínicos realizados con animales, decidieron aprobar y poner en las farmacias el Contergan (4) en medio de una agresiva campaña publicitaria. Ésta fue la primera denominación comercial de la talidomida. La nueva droga era a la vez tranquilizante y somnífera, y fue presentada como la solución contra los malestares del embarazo, puesto que se dijeron maravillas de este nuevo fármaco. 


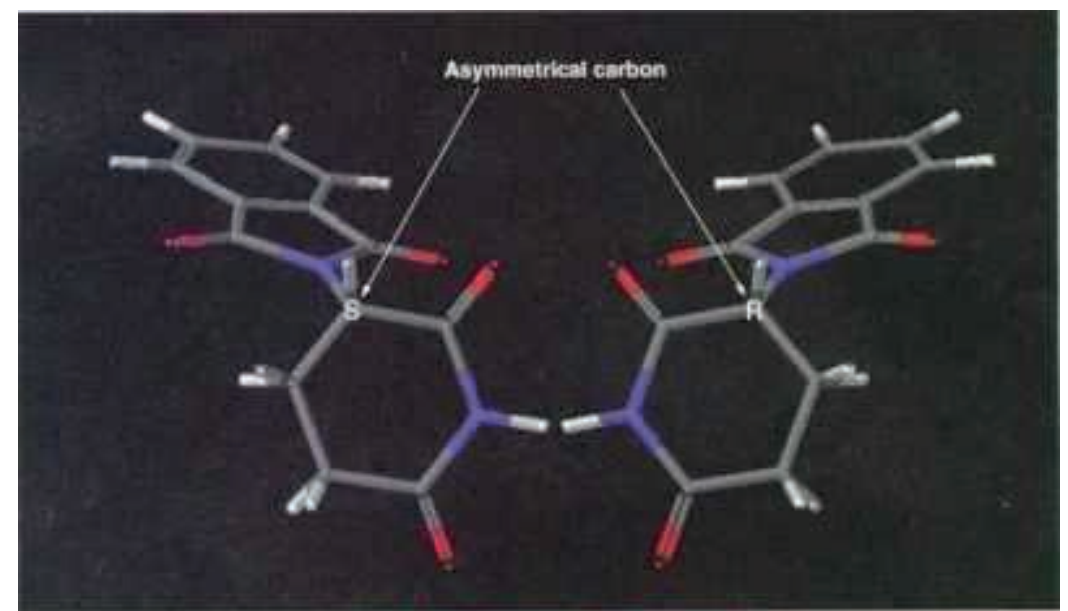

The Two Forms of Thalidomide

The $\mathrm{S}$-thalidomide molecule is on the left; its mirror image, $\mathrm{R}$-thalidomide is on the right. These two structures (technically called enantiomers) both have the same formula and are identical except for the pattern in which the bonds are arranged about the

"asymmetrical atom". S-thalidomide causes birth defects while R-thalidomide does not.

Imagen 1.

Foto: Colossus.chem.umass.edu

Un detalle de la composición química de la talidomida.

El Contergan se convirtió entonces en "la píldora milagrosa" y, en efecto, eso era lo que parecía: procuraba un sueño reparador, no era adictiva y, aún en dosis excesivas, no mataba como sí lo hacían los barbitúricos. Presentaba tan pocos riesgos que en algunas partes se vendía sin receta. En 1961, "la píldora durmiente del siglo" había vendido ya 1,5 millones de marcos de la época; los alemanes consumían un promedio de 15 millones de píldoras por año. En un artículo titulado en inglés "March 3, 1999: Pharmacological Hades" (5) (3 de marzo de 1999: Infierno Farmacológico), uno de los científicos de Chemie-Grünenthal que protagonizaron el lanzamiento de esta droga al mercado, no oculta su desazón cuando escribe: "Contergan tenía más ventajas que otras píldoras para dormir de entonces (...). La notoxicidad fue probada en un hombre de 21 años que ingirió 144 píldoras de Contergan Forte, 15 gramos completos de talidomida y sobrevivió sin presentar efectos secundarios visibles". 
Era tal la confianza de los fabricantes en la inocuidad de la píldora, que el medicamento se vendía con el rótulo: "Especialmente conveniente para el embarazo". Para colmo, el 3 de junio de 1961, un pediatra alemán envió a Chemie-Grünenthal una nota con dos preguntas sencillas, que recibieron una respuesta obvia...

"Pregunta 1. ¿La talidomida pasa por la placenta?

Respuesta: Desconocido.

Pregunta 2. ¿Puede la droga dañar el feto si pasa por la placenta?

Respuesta: Probablemente no".

Pero 1) pasó por la placenta y 2) dañó al feto seriamente. De eso se darían cuenta demasiado tarde.
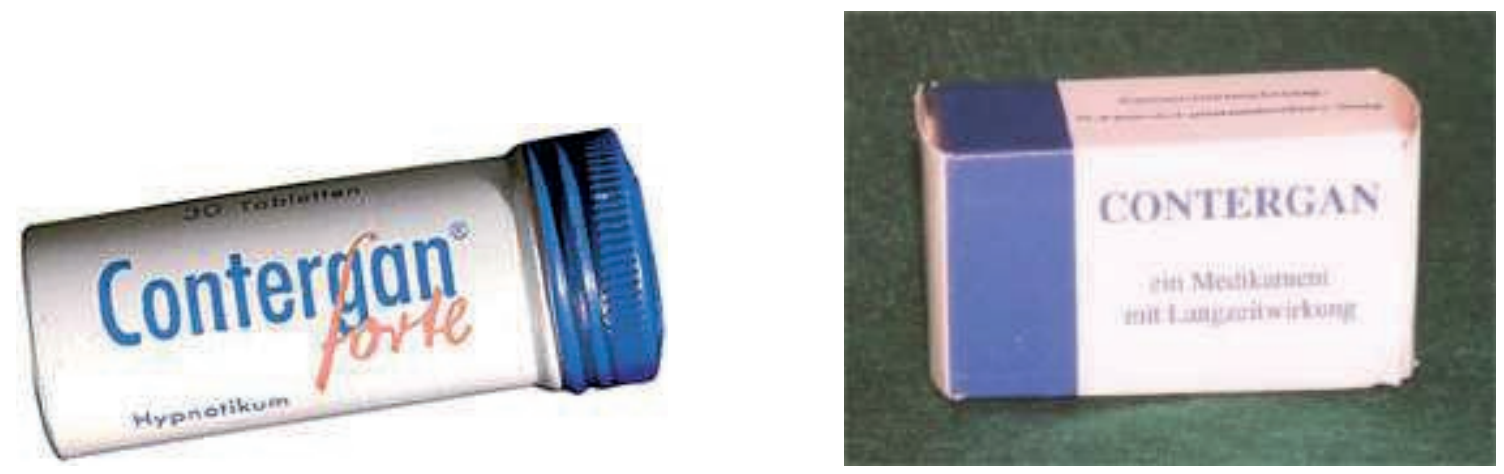

Imagen 2. Foto: Neundorf.de

Imagen 3. Foto: José Riquelme

El fatídico Contergan en sus dos presentaciones más populares: con ellas ChemieGrünenthal obtuvo millonarias ganancias a costa de los bebés malformados.

Sin embargo, pronto comenzaron las dudas. El 15 de noviembre de aquel año, el doctor Widukind Lenz (6), del Hospital de la Universidad de Hamburgo (7), llamó a un colega suyo, Heinrich Mückter, el inventor de la talidomida (Nota 1), para informarle que tenía 14 casos documentados de defectos del nacimiento y una 
posible conexión entre el Contergan y la polineuritis. Éste se encogió de hombros. Ya estaba "demostrado" que los centenares de nacimientos raros en Alemania Federal desde 1957 "no tenían ningún defecto extraño en los miembros u órganos internos". Aún así, el síntoma descrito por Lenz fue llamado Phocomelia, palabra derivada de las voces griegas phokos (sello) y melia (miembro), aunque otros lo bautizaron como "miembros de foca", debido a la forma que adquirían las extremidades malformadas de los bebés de la talidomida. Fue un campanazo de alerta que se escuchó a distancia, pero que pocos hicieron caso. Con esta afirmación Lenz se ganó la enemistad de los científicos de Chemie-Grünenthal.

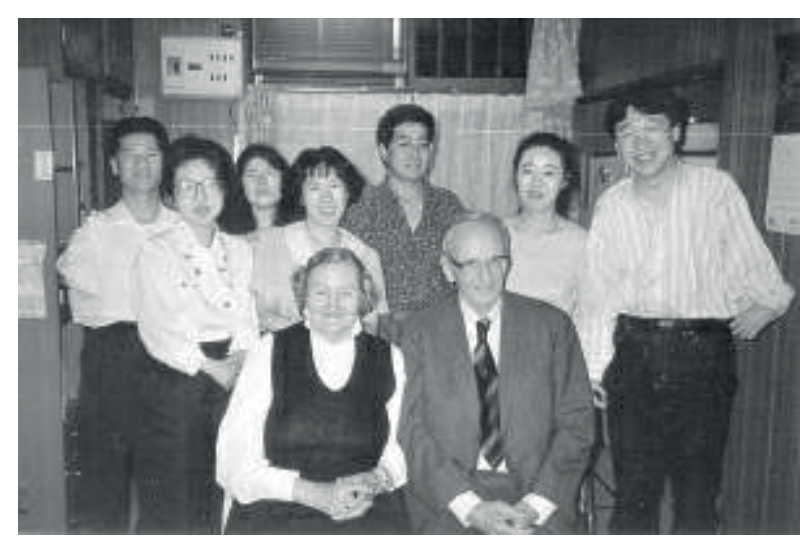

Imagen 4. Foto: Thalidomide.org

El doctor Widukind Lenz fue un gran científico que vivió preocupado por las víctimas de la talidomida, como demuestra esta toma, en la que aparece flanqueado por su esposa, posando junto a unas víctimas japonesas de la droga poco tiempo antes de su muerte.

Nota 1: El amigo murciano José Riquelme, en su futuro libro "Hijos de la Talidomida", cuenta que el doctor Mükter era un científico de los laboratorios alemanes Chemie-Grünenthal que tenía un pasado nazi. "El Dr. Mückter -relata Riquelme- realizó ensayos clínicos con piojos y cerdos, inyectando a humanos, en el campo de concentración alemán de Nuremberg. Muchos de ellos murieron. Fue uno de los 9 científicos de esta compañía farmacéutica que estuvieron sentados en el 
banquillo de los acusados, por haber fabricado y comercializado la Talidomida en casi todo el mundo".

\subsection{No, pero sí...}

El éxito comercial del Contergan fue objeto del interés de laboratorios farmacéuticos de otros países. Así, en diciembre de 1961, los derechos para la comercialización de la droga fueron vendidos a la firma sueca Astra (8). Poco después, la misma compañía advertía que su nuevo fármaco, el Neurosedyn (9), "podía ser peligroso para el feto", pues ya se sospechaba de una relación entre su principio activo y el nacimiento de 90 niños con malformaciones congénitas en Suecia. Pero los alemanes seguían bailando con el Contergan.

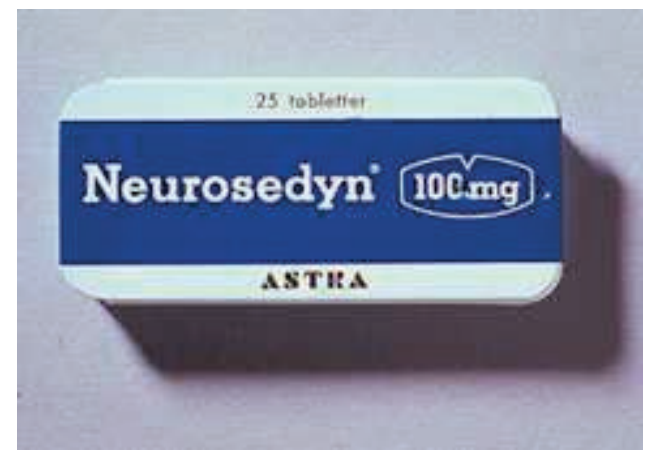

Imagen 5. Foto: Blivande Mammor/Vipeholm.lund.se

Fue una suerte encontrar esta foto, una cajita del Neurosedyn sueco. Nótese claramente el logo del fabricante, Astra.

A pesar de las advertencias de algunos especialistas extranjeros, la producción de talidomida aumentó y pronto comenzó a ser ofertada bajo otras denominaciones tales como Ectiluran, Glutanon, Imidan, Kevadon, Lulamin, Quietoplex, Softenon, Talargan, Tensival, Valgraine, Neosedyn, Nevrodyn, etc, en el resto de Europa, Asia y África, además de Norteamérica y América Latina. Es decir, mientras algunos expertos decían todo lo contrario, la industria farmacéutica insistía en su empeño de 
llenar el mundo con estas pastillas "milagrosas". En octubre de 1961, luego de extensas pruebas con animales, la firma británica Distillers Co. (10) puso a la venta otra variante del Contergan bajo el nombre de Distaval, con el siguiente rotulo en su etiqueta de presentación: "Distaval se puede dar con completa seguridad a las mujeres y a las madres embarazadas, sin efecto nocivo alguno sobre el feto". (11)

En 23 de febrero de 1962, se publicaron recién las primeras señales del peligro que acechaban a las mujeres embarazadas y a los fetos si ingerían la talidomida, diciendo que esta droga había sido puesta en el mercado luego de tres años de ensayos clínicos con animales.

Paralelamente a esto, comenzó la desmitificación de una droga que había sentado sus reales a pesar del horror que despertaba y el grito puesto en el cielo por muchos médicos. El Neurosedyn terminó siendo prohibido en Suecia, aunque más tarde que temprano. En este país habían nacido 153 niños con embriopatía, otra denominación de la focomelia. De éstos, unos 100 sobrevivieron, aunque se ignora cuántos llegaron a la edad adulta. Por algo se dice que la droga dañó una generación entera... y tal vez otras. Los niños del Neurosedyn crecieron con ese estigma.

\subsection{Pesadilla farmacológica}

Los médicos, y sobre todo las autoridades de los países implicados en este drama, tomaron conciencia de la situación cuando hubo varios casos en distintas partes del mundo, al parecer sin relación alguna entre ellos: comenzaron a nacer niños deformados, víctimas de la talidomida. El común denominador de estas anomalías era, a primera vista, la ausencia de la mayor parte del brazo y la presencia de manitas en forma de aleta que se extendían directamente desde el hombro, dando lugar a la denominada focomelia o miembros de foca. Otra deformidad frecuente era la aplasia radial, la ausencia del pulgar y del hueso adyacente en el antebrazo. En las 
extremidades inferiores se produjeron deformidades similares. La deformidad de los bebés afectados casi siempre ocurría a ambos lados y a menudo tenían deformidades tanto en los brazos como en las piernas. Además de las extremidades, la droga causaba deformidades en los ojos y las orejas, los genitales, los riñones, el conducto digestivo (inclusive los labios y la boca) y el sistema nervioso. Se reconoció a la talidomida como un teratógeno (una droga o agente de otra índole que causa el desarrollo anormal del embrión o el feto).

"Unas veces tenían las piernas retorcidas -escribe un periodista de la desaparecida revista LIFE en español, cuando recordaba el espanto de los padres al ver a sus hijos nacer con malformaciones congénitas por culpa de la talidomida (12) - , otras presentaban también deformidades internas. En la mayoría de los casos, sin embargo, no había al parecer deficiencias mentales." Para algunas mujeres, la talidomida resultó ser tan tóxica in útero que tuvieron abortos espontáneos.

Aquello se estaba transformando en una verdadera epidemia. Y, siguiendo el ejemplo de algunos de sus colegas alemanes, los médicos de países tan distantes como Australia o Bélgica, comenzaron a asociar tales deformidades con la talidomida. Las sospechas quedaron confirmadas cuando los padres de algunos niños deformados empezaron a facilitar datos a los especialistas, lo que permitió descubrir una serie de coincidencias que los llenaron de horror: la mayoría de las madres de niños afectados habían ingerido la píldora en el segundo mes del embarazo, precisamente el mes en que se forman los brazos y las piernas del feto. 


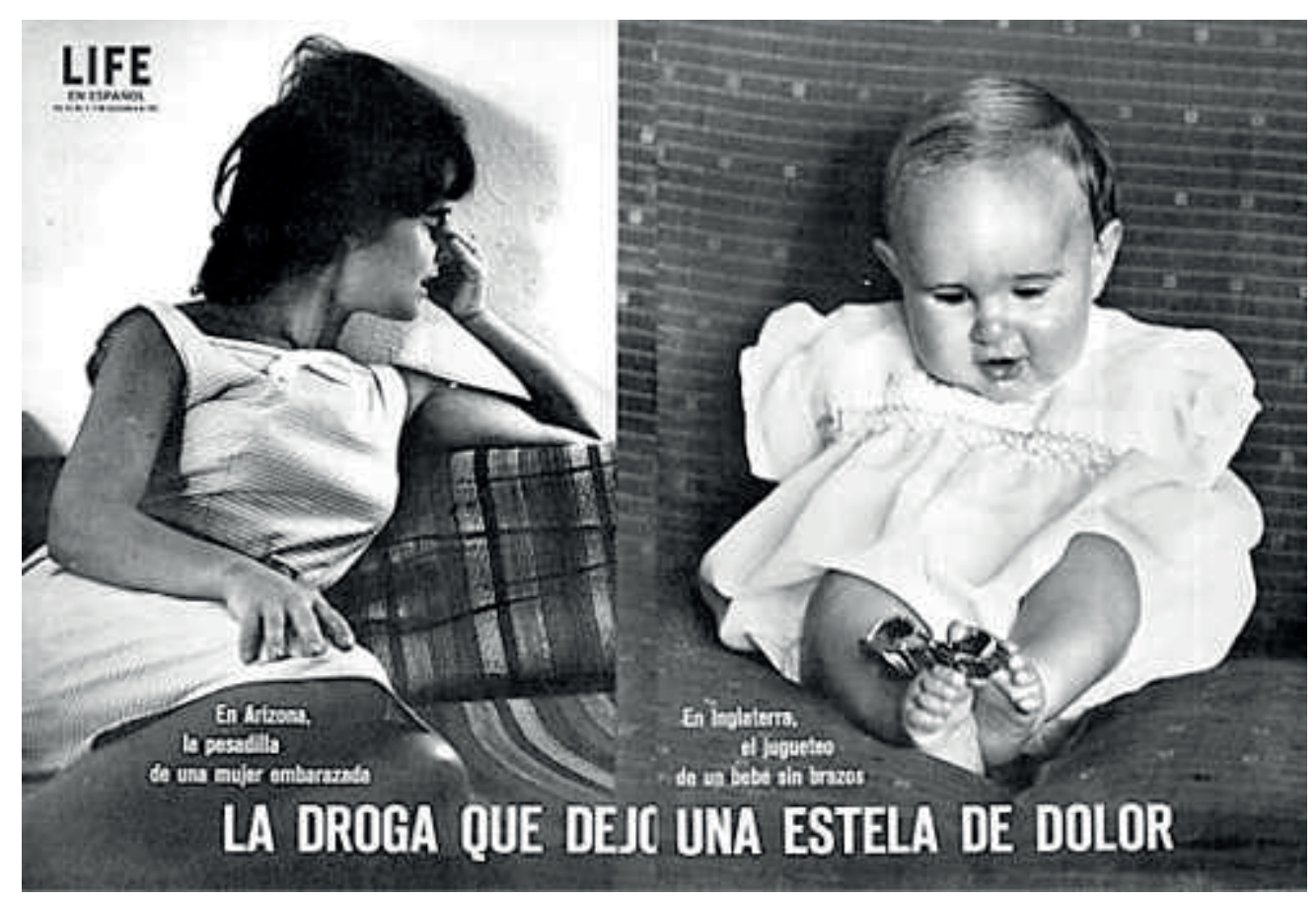

Imagen 6. Foto: LIFE en español.

Desesperación. "En Arizona, la pesadilla de una mujer embarazada. En Inglaterra, el jugueteo de un bebé sin brazos".

José Riquelme, una víctima española de la talidomida, quien viene ultimando un exhaustivo libro dedicado a este fármaco y las tragedias que ha provocado, nos describe el mismo panorama desolador de aquellos días: "Los efectos de la talidomida aparecían en forma de malformaciones congénitas en las orejas, defectos internos y, particularmente, deformaciones de las extremidades. En los casos más extremos, se presentaba como focomelia. Síndrome que se caracteriza por la ausencia total o parcial de brazos y/o piernas, con las manos y pies a modo de aletas, que nacen directamente de los hombros. Así como graves malformaciones en las piernas..."

\subsection{Mujeres al borde de un ataque de nervios}


Riquelme cuenta también que muchos de los bebés de la talidomida no sólo venían al mundo con total o parcial ausencia de brazos y/o piernas, sino que, en muchos casos, las extremidades, si es que se les podía llamar así, tenían tres deditos en cada mano o pie, como si se tratara de aletas, que nacían directamente de los hombros, rodillas o ingles. En otras ocasiones, estos efectos congénitos de la talidomida aparecían como amputaciones. Las malformaciones talidomídicas, empero, sólo afectaban formaciones orgánicas estructurales periféricas o funciones motoras, no así órganos vitales como el cerebro, que, como comenta Riquelme, por la ley de la compensación, se desarrollaba extraordinariamente.

Pero no todas las partes del organismo resultaban dañadas. Así, por ejemplo, se observó que los órganos reproductivos se desarrollaban sin problemas en las personas afectadas, hasta el punto de que podían tener hijos enteramente normales, no habiendo quedado demostrado todavía -como algunos temen - que las malformaciones talidomídicas puedan ser transmitidas de padres a hijos (Nota 2), condición que ciertamente forma parte más de la polémica que de un hecho científico concreto, tal vez porque estamos viviendo aún las dos primeras generaciones de víctimas de la talidomida y porque, hasta ahora, no se ha visto nunca que un fármaco rompa las barreras generacionales.

Nota 2: Más información sobre este discutido asunto en el capítulo 14: ¿La talidomida afecta el código genético?

Por el mundo se extendió, entonces, la angustia, el miedo, la indignación y también la psicosis. La paranoia enfermaba como la enfermedad. De sólo pensarlo, la idea, en sí misma, aunque no fuera cierta, provocaba una reacción alérgica o un shock psíquico. Algunos autores calificaron este verdadero desastre farmacológico como "la m... golpeando el ventilador", debido a que se propagaba raudamente por todas partes. Había padres que llegaron a pensar en el aborto cuando se enteraron que la 
droga podía malformar a su bebé, o en la eutanasia cuando éste nacía con anomalías congénitas. Millares de mujeres embarazadas de todo el mundo sufrieron un choque emocional -incluso necesitaron ayuda profesional - al imaginarse haber consumido el Contergan o el Kevadon durante el periodo en que el feto desarrolla las extremidades. "Si usted las tomó en tal periodo menstrual, en tal momento, su hijo nacerá sin piernas o sin brazos", se decía.

Con el descalabro total de la inocuidad de la talidomida, sus tan voceadas denominaciones comerciales -en número de 68, según la base de datos de la Asociación de Víctimas de la Talidomida del Canadá TVAC (13) - quedaron enterradas en el descrédito, aunque algunas de ellas siguieron haciendo de las suyas después de que la droga fuera prohibida a nivel mundial.

\section{Las tribulaciones del Kevadon I}

\subsection{Una heroína en el gabinete}

John Mulliken, un veterano hombre de prensa de la revista LIFE (14) de aquel entonces, sin quererlo, rindió homenaje a un singular personaje, una desconocida funcionaria de la FDA de Washington, la doctora Frances Kelsey (15), al escribir su artículo titulado: "La doctora que se resistió a los apremios". Después de mucho pensarlo decidimos transcribirlo al completo. El lector descubrirá que vale la pena.

"La solicitud fue presentada por la William S, Merrell Co. (16), antigua firma farmacéutica de Cincinnati. Cuando llegó al despacho de la doctora Kelsey en tres gruesas carpetas, todo parecía cuestión de simple rutina. La Merrell solicitaba a la Administración de Alimentos y Drogas (A.A.D.) (17) que estudiara el caso y otorgara el permiso necesario para poner a la venta, bajo prescripción médica, una droga llamada talidomida, con el nombre comercial de Kevadon (18); por toda referencias, parecía la píldora perfecta contra el insomnio. Las carpetas contenían datos 
completos de las pruebas clínicas y farmacológicas, así como de experimentos con animales realizados por la Merrell, y dado el extraordinario éxito de la talidomida en Europa, la firma interesada quería introducirla en el mercado norteamericano.

A la Dra. Frances Kelsey, farmacóloga, médica, y madre de dos hijos, el trámite de la solicitud le pareció aún más fácil que de costumbre. Pero, por otra parte, sabía que era su deber proceder con cautela, y escuadriñar hasta la más mínima probabilidad de que la droga fuera nociva. Conforme empezó a leer el contenido de las carpetas, la Dra. Kelsey se sintió más y más intranquila. "Había algo diferente en este producto -dice - y me pareció mejor estar completamente segura." Por ejemplo, la droga no tenía el mismo efecto en los animales: no los ponía a dormir. La Dra. Kelsey empezó por el principio, o sea, a estudiar la talidomida como si no se hubiera usado nunca.

Como parte del trámite de la solicitud, la Merrell había enviado ya la droga a algunos médicos norteamericanos -cuyo número llegó a 1,200 - para que la pusieran a prueba. Este era el procedimiento acostumbrado que el mundo farmacológico y permitido por la ley, antes de que la droga fuera definitivamente autorizada. La mayoría de los médicos, no obligados por la ley a informar a sus pacientes del uso experimental de la droga, dieron informes favorables. El producto era eficaz e inocuo, tal como afirmaba la Merrell. La firma también ponía de relieve el éxito del producto en Europa, pero la Dra. Kelsey no se dejó impresionar por ello. "no podemos verificar los estudios hechos en el extranjero - y por consiguiente no debemos fiarnos de la documentación que viene de allí." 


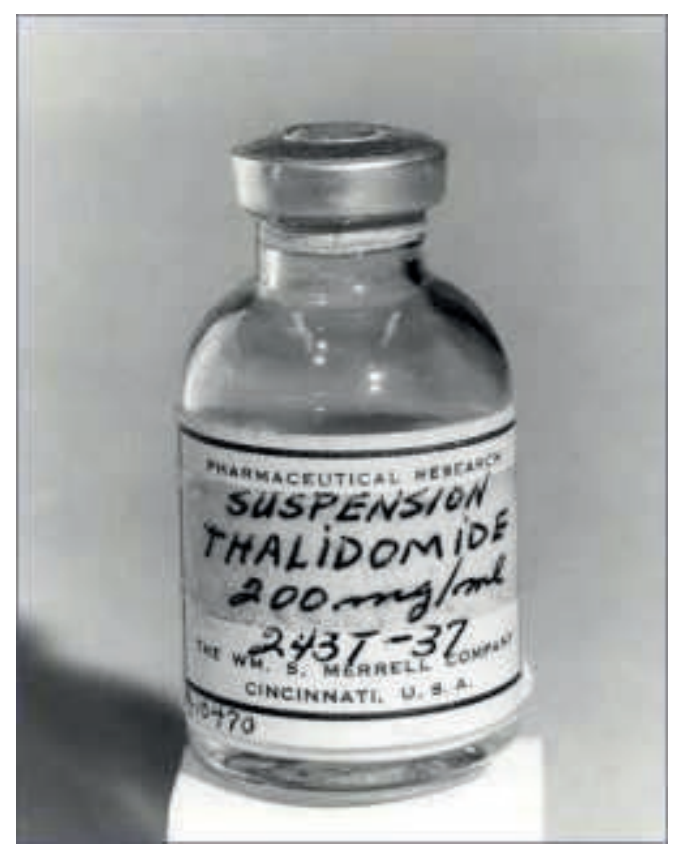

Imagen 7. Foto: Historywired.si.edu

Talidomida inyectable. Una verdadera rareza farmacéutica, esta imagen la encontramos en la base de datos oficial de la Historia de los Estados Unidos. Esta es una de las famosas "muestras médicas" que la casa Merrell repartió a miles de médicos de este país para que la entregaran a sus pacientes en calidad de "ensayo", mientras esperaba una autorización para el lanzamiento de su producto Kevadon, que nunca llegó.

De acuerdo con una ley promulgada sobre esta materia en 1938, la Merrell podía lanzar al mercado el Kevadon si no recibía noticias de Washington en el término de 60 días, contados a partir de la fecha de presentación de la solicitud. Por tanto, con objeto de evitar que el Kevadon llegara a las farmacias, la Dra. Kelsey escribió a la casa Merrell advirtiéndole que las pruebas presentadas se consideraban "incompletas".

Desde aquel momento quedó entablada la batalla entre "la burócrata empecinada" y el fabricante. "Parecía que los representantes de la firma llegaban a Washington en bandadas. Escribían cartas y llamaban por teléfono hasta tres veces por semana. Se 
comunicaban con mis superiores, que también venían a verme." Los altos empleados de la compañía se quejaban de que la Dra. Kelsey era poco razonable e irresponsable. Después de todo, ya se usaba la droga en todos los países civilizados".

\subsection{Papelito manda...}

"La mayoría de las cosas que me decían no podrían publicarse", añade la Dra. Kelsey. Aún bajo esta fuerte presión, la Dra. Kelsey continuó escribiendo cartas a la firma Merrell -para comunicarle que la información contenida en la solicitud estaba todavía incompleta - hasta que en febrero de 1961 descubrió el primer dato que venía a confirmar las sospechas que había dirigido durante seis meses. Perdida en la columna de cartas a la redacción del British Medical Journal, había una nota en que un lector advertía que estaban llegando informes a una compañía de Inglaterra sobre "el posible peligro tóxico de esa droga sedativa..." y que había "síntomas negativos de neuritis periférica en pacientes tratados con talidomida por periodos de seis meses o más". En los meses siguientes se recibieron noticias de otros casos. Persistían los indicios de que la droga podía causar insensibilidad, temblor, hormigueo en las manos y otras perturbaciones sensorias y motoras. La Dra. Kelsey no se alegró, porque ésta no era una victoria que pudiera celebrarse. Simplemente, la tranquilizó saber que había tenido razón.

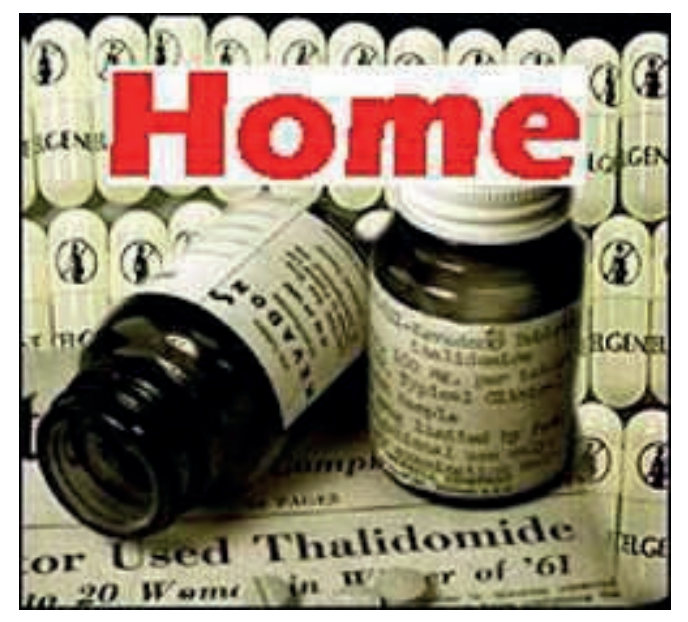

Imagen 8. Foto: chm.bris.ac.uk

Malos auspicios. El Kevadon había tenido mucho "éxito" en Canadá, pero no tuvo la misma fortuna en Estados Unidos, aunque la droga llegó a muchas madres por otros medios. 
Entre tanto, la firma Merrell, aunque no convencida de que la droga fuera tóxica, envió investigadores a verificar los informes sobre el terreno, en la Gran Bretaña. Lo que esos investigadores descubrieron no era concluyente, e insistieron en que no se había establecido una relación clara entre el uso de la talidomida y los síntomas neuropáticos. Por una parte, la incidencia (de un caso entre 3,000) era demasiado baja para alarmarse. Por otra -pensaba la compañía - los malos efectos se manifestaban especialmente en personas de edad avanzada, particularmente mal alimentadas y con deficiencias vitamínicas. La Dra. Kelsey trató de comprender la actitud de la firma Merrell: "Debe ser muy diferente cuando se ha hecho una considerable inversión en el perfeccionamiento de una droga. Supongo que ellos y yo discrepamos más que nada sobre la importancia de las precauciones que deben tomarse con una droga que se va a vender en el mercado."

La firma preguntó entonces a la Dra. Kelsey si aprobaría la droga en caso de que los fabricantes pusieran un rótulo de advertencia de que podría producir ciertas reacciones. Todavía en el mes de octubre (de 1961) la Merrell recordaba a la Dra. Kelsey que, si no se apuraba, ellos perderían "las ventas de Navidad". La doctora se negó a apurarse. Escribía una carta cada vez que era necesario para impedir la circulación de la droga. "Huelga decir que mucha gente me recordaba que el plazo de 60 días había pasado", dice ella recordando esa circunstancia.

Pero a fines de noviembre todo se aclaró. Todas sus sospechas, toda su paciencia, quedaron justificadas. De la Alemania Occidental se recibió la noticia de que un tal Dr. Lenz explicó en un discurso que cierta droga quizás fuera la causante de la focomelia "epidémica" que se venía propagando por su país en los últimos tres años. Lenz no mencionó el nombre de la droga, pero poco después, otro médico le preguntó: ¿Podría usted decirme confidencialmente si la droga es Contergan? Le pregunto porque nosotros hemos tenido un focomelo y mi esposa tomó Contergan". Lenz tuvo que admitir que sí lo era. 
Otros relatos trágicos empezaron a llegarle a la Dra. Kelsey de Australia, Suecia, Bélgica, Suiza, Líbano, Israel y Perú, todos ellos relativos a madres de niños deformes que habían tomado la talidomida en una u otra forma.

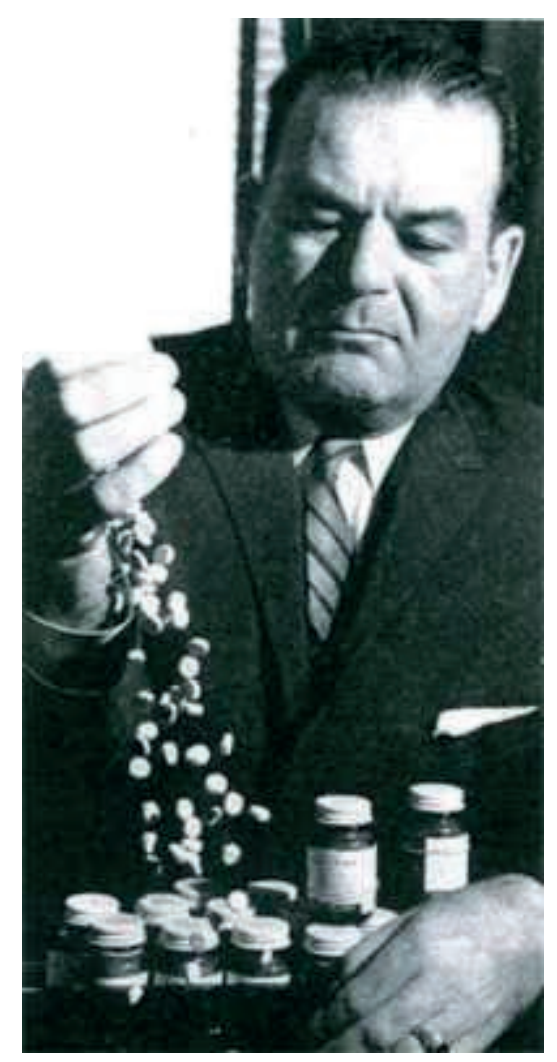

Imagen 10. Foto LIFE en español

Píldoras desparramadas. El director de sanidad de Chicago, Samuel Andelman, manipula un frasco del calmante Kevadon.

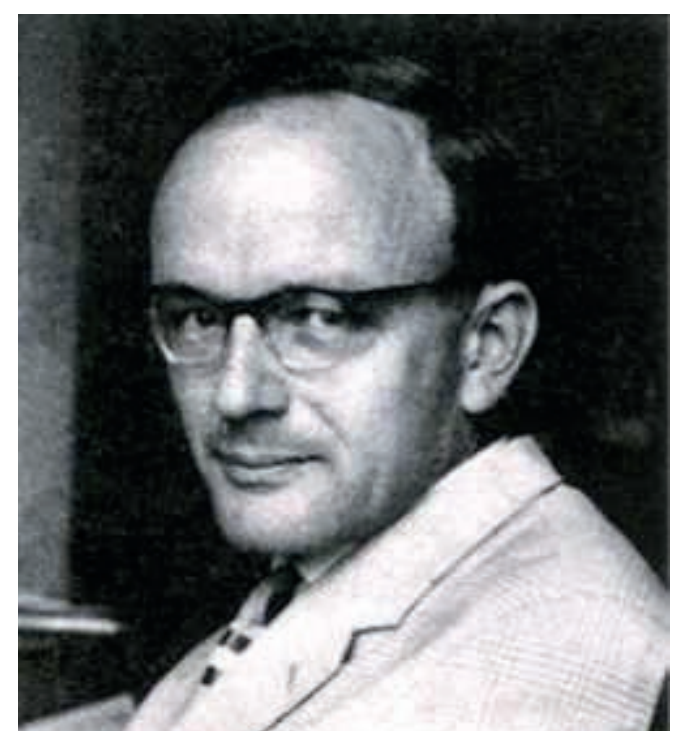

Imagen 9. Foto LIFE en español

Pionero. El doctor Widukind Lenz dio la voz de alerta sobre el peligro de la talidomida cuando, a fines de 1961, advirtió una relación entre el Contergan y los bebés con malformaciones congénitas que estaban naciendo por toda Europa, especialmente en Alemania. 
El 26 de noviembre, el Contergan fue retirado del mercado alemán. La firma Merrell, que informó a la Dra. Kelsey sobre el descubrimiento del Dr. Lenz, suspendió sus trámites relativos al Kevadon ante la A.A.D. en cuanto supo lo del discurso, e inmediatamente envió a sus investigadores otra vez a Europa. En marzo (de 1962) (Merrell) retiró oficialmente la solicitud.

La firmeza de la Dra. Kelsey evitó innumerables tragedias y al mismo tiempo le valió felicitaciones inesperadas. El presidente Kennedy, con rapidez sin precedentes en estos asuntos, le otorgó la Medalla Presidencial por Servicios Distinguidos, el galardón más importante que concede el gobierno norteamericano a civiles. Fue un acto de reconocimiento universalmente aplaudido. Una mujer de gran fortaleza moral y rectitud había demostrado que a veces debe aminorarse la marcha de las ruedas del progreso para poder examinarlas."

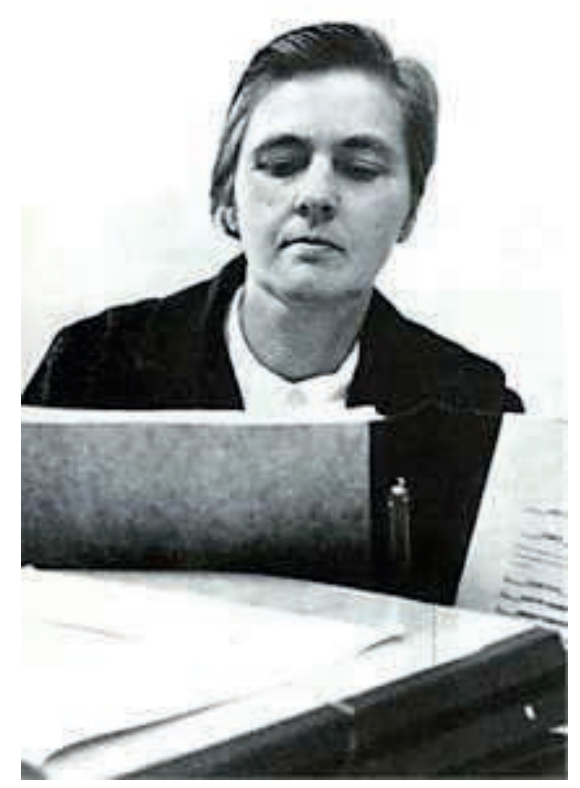

Imagen 11. Foto: LIFE en español

Rebelde con causa. La doctora Frances Kelsey, una oscura funcionaria de la FDA, se convirtió sin quererlo en el baluarte contra los potenciales peligros de la droga Kevadon que la casa Merrel quería introducir en el mercado estadounidense. 


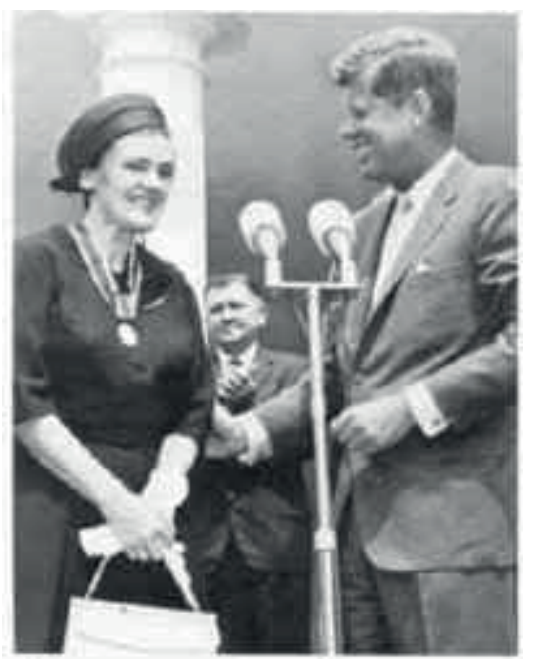

\section{Imagen 12. Foto: FDA Consumer}

Honor al mérito. Impedir la entrada del Kevadon en los Estados Unidos le valió a la doctora Kelsey recibir la Medalla Presidencial por Servicios Distinguidos, galardón que recibió de manos del entonces presidente John F. Kennedy.

Como corolario: en medio de la tormenta que desató la aventura canadiense del Kevadon, la talidomida nunca fue aprobada por la Food and Drug Administration de los EE.UU., a pesar de que los laboratorios Merrell casi ganan una batalla de oficios y telefonazos que había durado 14 meses.

\section{Las tribulaciones del Kevadon II}

\subsection{Una fábrica Merrell desconcertada...}

En el otro extremo de la historia, quince meses después de que la droga Contergan fuera puesta en el mercado en Alemania Occidental, en octubre de 1959, y a tres años de haber recibido todos los informes favorables sobre sus efectos clínicos en seres humanos, la Chemie-Grünenthal recomendó su introducción en Norteamérica. En ese mismo año, la firma Merrell, de Reeding, Ohio, comenzó a producir talidomida para el mercado canadiense bajo el nombre de Kevadon. Pero la cosa se complicó cuando quiso introducir el producto en los Estados Unidos, un país de legislación muy estricta para la fabricación y venta de medicamentos.

A fin de cumplir con las leyes estadounidenses, la Merrell decidió investigar más a fondo la talidomida. "En las pruebas que hicimos con la talidomida -escribió en su 
oportunidad el doctor Carl A. Bunde en la revista LIFE en español- seguimos el procedimiento normal de las firmas farmacéuticas más respetables de los EEUU. No teníamos prisa. Estuvimos 20 meses probando la droga en nuestros laboratorios y la distribuimos a título experimental entre médicos escogidos."

En noviembre de 1960, la Merrell presentó el informe de sus investigaciones junto con los datos recibidos del extranjero -particularmente de Alemania, Inglaterra y Canadá - a la Administración de Alimentos y Drogas de Washington (más conocida como FDA). "Había importantes diferencias entre nuestro plan de estudios y el de Europa -explica Bunde- - Nuestros médicos investigadores evaluarían los efectos de la droga sobre la náusea del embarazo incipiente. Nuestro plan de estudios se encaminaba a perfeccionar una prescripción para uso en pacientes de edad más avanzada, hospitalizados, y en ciertas situaciones especiales como los de casos ortopédicos y psiquiátricos."

En aquellas pruebas, la droga parecía ser inofensiva y eficaz. "Desde septiembre de 1960 hasta noviembre de 1961 -continúa el especialista - hubo diferencias de criterio científico entre la compañía Merrell y los funcionarios médicos de la A.A.D. No era la primera vez ni será la última que los científicos discrepan. La A.A.D. hizo más de 50 preguntas y peticiones a la Merrell sobre una infinidad de aspectos, detalles de análisis químicos, mejores traducciones de los informes recibidos del extranjero, inspección de la fábrica de talidomida en la Alemania Occidental (ChemieGrünenthal), investigación de los procedimientos de mezcla en la manufactura y datos sobre el uso de ésta en el embarazo avanzado y el posible efecto secundario de la neuritis periférica". 


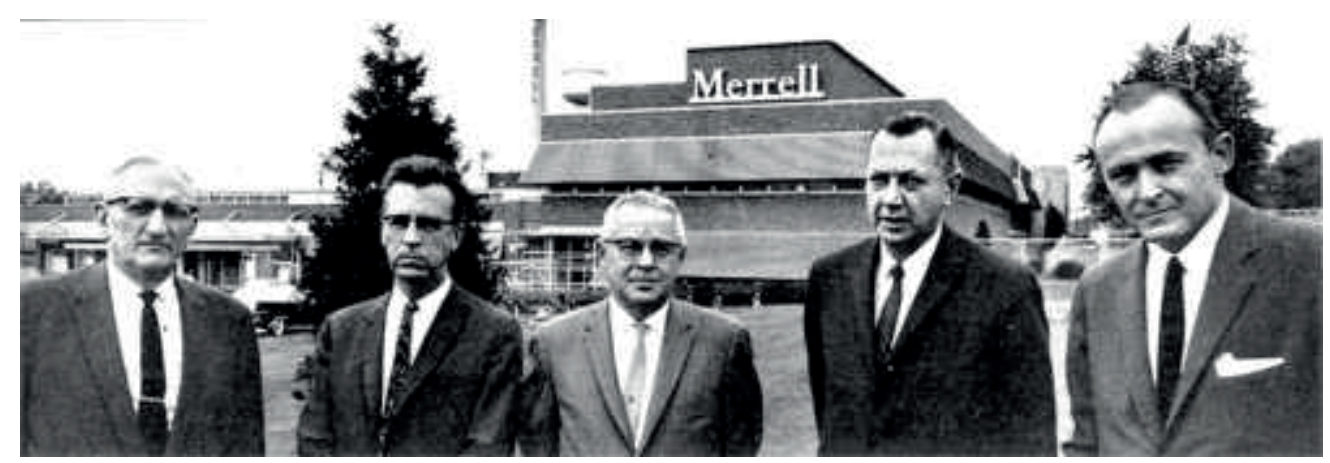

Imagen 13. Foto: Revista LIFE en español

"En defensa de su caso. Frente a su fábrica principal, en Reeding, Ohio, los jefes de la compañía William S. Merrell encaran las críticas con un informe de los métodos que siguieron para solicitar el permiso de venta. Nelson M. Gampler, se ve a la izquierda junto al Dr. Carls A. Bunde, director de investigaciones médicas."

(Leyenda publicada por LIFE)

Según dicha información, por espacio de catorce meses hubo 58 contactos entre la Merrell y la A.A.D. en forma de visitas personales, llamadas telefónicas o cartas. Diez de estos contactos fueron iniciados por la A.A.D. "En 22 casos -prosigue Bunde-, la Merrell estaba suministrando la información pedida por la A.A.D. En todos, menos cinco casos, el contacto con la A.A.D. en Washington fue hecho por una sola persona. Una vez se realizó una conferencia con ocho médicos. Fuera de esto, no más de dos personas de la Merrell visitaron al mismo tiempo las oficinas de la A.A.D."

\subsection{El desaliento tardío}

"La cuestión de la neuritis periférica (inflamación de los nervios de las extremidades) ocupó la mayor parte de tiempo. La Merrell tomó la iniciativa en febrero de 1961, al investigar las informaciones que aparecieron publicadas en el British Medical Journal (19). Inmediatamente pedimos a Londres más pormenores, Enviamos a dos de nuestros científicos a Europa e informamos también inmediatamente a la A.A.D., sobre los resultados de este viaje de inspección." 
No obstante, pronto llegaron las primeras noticias alarmantes. En septiembre de 1961, dos supuestos casos del efecto secundario de la talidomida, observados en los Estados Unidos, no se habían curado del todo. Aunque estos casos quedaron descartados posteriormente, permaneció abierta la sospecha acerca del posible efecto de esta droga sobre las mujeres embarazadas y los bebés. Los temores quedaron confirmados al quedar suspendida la solicitud de la Merrell de comercializar el Kevadon, que debía lanzarse al mercado estadounidense bajo la denominación comercial de Kevadon. El 30 de noviembre de aquel año, dos médicos de la Merrell se presentaron ante el Directorio de Alimentos y Drogas de Ottawa, Canadá. Otros dos médicos volaron a Europa a recoger información, y se hizo una advertencia a los investigadores clínicos de la compañía farmacéutica, para que no administraran la droga de prueba a mujeres que estaban embarazadas.

"Nuestra primera información procedente de Europa era incompleta -prosigue el relato del doctor Bunde-. Entre los datos que se nos enviaron relativos a 20 casos, no había evidencia de que más de la mitad de las madres hubieran tomado talidomida en el comienzo del embarazo. En muchos casos, habían usado simultáneamente de dos a 12 drogas más. Otros factores complicaban el problema.

La compilación de datos significativos ha sido difícil -prosiguió el médico - , ha sido sumamente difícil. No hemos minimizado la posibilidad de que la talidomida pudiera estar relacionada con las deformidades congénitas de alguna manera no esclarecida todavía."

La doctora Kelsey, sin embargo, se encargó finalmente de poner los puntos sobre las íes: la talidomida no se vendió en los Estados Unidos en aquel entonces, al menos oficialmente. 


\section{Alarma en el Sur...}

De nuevo nos remitimos a la inolvidable revista LIFE, testigo presencial de tantas historias humanas. En Latinoamérica la talidomida contó con muchos aliados que la permitieron hacer de las suyas entre nuestros pueblos.

"En América Latina, cundió la aprensión y la angustia al conocerse los mutilantes y trágicos efectos de la talidomida. Pero felizmente se conocen pocos casos hasta ahora (Nota 3), de deformaciones. Los principales países afectados han sido Brasil y Argentina. En éstos, como en los demás países en que se vendía la droga, las autoridades han prohibido su elaboración, venta y consumo. Hay dos casos confirmados, en Buenos Aires, de niños deformados por la talidomida, pero no existen ni siquiera cálculos del número de mujeres embarazadas que han ingerido el tranquilizante. Las empresas farmacéuticas, por iniciativa propia, suspendieron hace unos tres meses la elaboración de medicamentos basados en la talidomida, pero no retiraron los productos ya entregados a las farmacias. En los primeros días de agosto, un grupo de médicos, alarmados por las noticias que llegaban de Europa, celebraron una reunión. Más tarde, el Dr. Erico Von der Walde, de Buenos Aires, entregó un informe al Ministerio de Salud Pública en que denunciaba la venta ininterrumpida de la droga en las farmacias. El ministro, Dr. Tiburcio Padilla, anunció entonces que se dictarán las disposiciones necesarias para evitar que la droga llegue al público. En el Brasil también se ha vendido mucho lo que la prensa ha dado en llamar la "droga maldita", con nombres tales como Slip, Sedin y Sedalis. La primera víctima, Julita Campos, nació sin brazos en mayo, en Sâo Paulo. En lugar de brazos tiene dos manos deformadas adheridas a los hombros. Una maestra de escuela de Porto Alegre dio a luz gemelos deformes, y las esposas de dos médicos del interior de Río Grande do Sul, a quienes ellos mismos recetaron la droga, también tuvieron niños con extremidades defectuosas. Han ocurrido otros casos, especialmente en las grandes ciudades, pero los detalles no han sido facilitados al público. En Río de Janeiro, tres 
desconocidos golpearon a un farmacéutico y le advirtieron: "Para que no siga vendiendo la muerte". Los productos con contenido de talidomida están elaborados por tres empresas de Sâo Paulo, pero el 2 de abril (de 1962), el Servicio Médico Nacional canceló el permiso de elaboración y ordenó la confiscación de la droga. No ha sido fácil confiscar las existencias. Una sola de las empresas fabricantes la había vendido a más de 6.000 farmacias. Al confirmarse los efectos desastrosos de la talidomida, las autoridades de Sâo Paulo, que es donde más se vendió la infernal droga, iniciaron un "blitz" encaminado a eliminar todo vestigio de ella. Doce grupos de médicos están investigando las 1.800 farmacias de Sâo Paulo, y otros catorce grupos viajan de pueblo en pueblo consultando con farmacias y médicos. La venta de la droga ha sido declarada delictuosa, y se ha prohibido a las farmacias vender tranquilizantes de ninguna clase sin prescripción médica. En México se ha vendido la droga desde 1959 con el nombre de Talargan, pero no han ocurrido casos conocidos de partos anormales. El talargan fue retirado del mercado hace unos cuatro meses. En Perú, donde la droga fue prohibida en junio pasado, se informa que en el mes de agosto han ocurrido dos casos. (Nota 4) En los próximos meses se sabrá hasta qué punto han sido afectados los niños por nacer en la América Latina."

Nota 3: Recuérdese que este artículo fue publicado en la edición de la revista LIFE correspondiente al 17 de septiembre de 1962.

Nota 4: El autor del presente reportaje viene realizando desde hace dos años (2000 2002) una exhaustiva búsqueda de información sobre el fenómeno de la talidomida en el Perú. Para ello se recurrió a especialistas de Essalud (el Seguro Social peruano) (20), al Colegio Médico peruano (21) y a genetistas, pediatras, cirujanos, farmacéuticos, y el resultado ha sido nulo, salvo la referencia proporcionada hace dos años (2000) por el doctor Germán Posadas, neurocirujano pediátrico del Hospital Edgardo Rebagliati de Lima (ex Hospital del Empleado de Lima), quien realizó una pequeña encuesta entre especialistas de dicho centro de salud, pero ninguno, al 
parecer, estaba enterado de ello, aunque recordó algunos artículos sobre este tema publicados hace unos meses en el diario limeño Gestión (22). En todo caso, algunos médicos internistas informaron que este producto -la talidomida - "tiene la proyección de ser usado en el tratamiento de algunas neoplasias a nivel de órganos del abdomen, extra-neurológicos". "Lo que si estoy seguro -dijo en aquella ocasión el Dr. Posadas - es que dicho medicamento no está dentro del petitorio del Ministerio de Salud para dar el pase formal pertinente -según información de representantes de dicho ministerio y de la Sociedad de Farmacología del Perú".

\section{La talidomida en el Perú}

\subsection{La incongruencia del CENAFIM}

Por otro lado, en un reportaje fotográfico publicado en una edición de 1962 de la revista LIFE en Español, que habla del escándalo que se suscito en aquel entonces debido a las trágicas secuelas que dejó este fármaco en miles de niños en todo el mundo, aparece una lista bajo el rótulo "Ojo con estas drogas" (ver cuadro de abajo), donde aparecen los nombres de 52 fármacos derivados de la talidomida -contra los 68 que menciona la investigación realizada por la Asociación de Víctimas de la Talidomida del Canadá (TVAC) - , entre los cuales figuran los nombres de tres medicamentos que presuntamente habrían circulado en el Perú -y de los que hay cierta constancia de su existencia en el mercado peruano-, comercializados en las boticas y farmacias limeñas entre los años ‘60 y' 90 .

\section{OJO CON ESTAS DROGAS}

La talidomida, pura o mezclada con otras drogas, se ha estado vendiendo por lo menos con 52 nombres, cuya lista damos a continuación. Si tiene usted en su poder alguna de estas drogas, deshágase de ella o entréguela a su médico. 


\begin{tabular}{|c|c|c|}
\hline Algosediv & Lulamin & Sedalis \\
\hline Asmadion & Neo Nibrol & Sedimida \\
\hline Asmaval & Neosydyn & Sedin \\
\hline Bonbrrin & Neurosedyn & Sediserpil \\
\hline Calmorex & Nevrodyn & Sedoval-K17 \\
\hline Contergan & Noctosediv & Slip \\
\hline Coronarobetin & Noxodyn & Softenil \\
\hline Distaval & Peracon Expectorans & Softenon \\
\hline Ectiluran & Poly-giron & Talarfan \\
\hline Enterosediv & Poligripan & Talimol \\
\hline Gastrimide & Prendísediv & Tensival \\
\hline Glutanon & Profarmil & Thalin \\
\hline Grippex & Psycholiquid & Thalinette \\
\hline Imidan & Psychotablets & Theophilcoline \\
\hline Imidene & Quetimid & Ucerfen \\
\hline Isomin & Sanodormin & Valgraine \\
\hline Imidene ipnótico & Quietoplex & Valgis \\
\hline
\end{tabular}

Fuente: Revista LIFE en español - 17 de septiembre de 1962

La lista de LIFE menciona el Enterosediv, el Sedalis y el Softenil -este último, por cierto, es el único fármaco de talidomida citado por la antes mencionada lista del TVAC, en el recuadro correspondiente al Perú, mientras que las referencias de los otros dos medicamentos fueron encontradas gracias a distintas fuentes-. La revista LIFE, coincidentemente con otros informes consultados, menciona también la existencia de dos casos de malformaciones talidomídicas en el Perú como mínimo, con la sospecha de que por lo menos uno de ellos fue en Lima. Esta versión, sintomáticamente, nos recuerda noticias más recientes que hablan de posibles casos de niños con focomelia talidomídica en la selva amazónica, particularmente en la 
zona de Pucallpa (Nota 5), capital del departamento peruano de Ucayali, una región plagada por la lepra y otras enfermedades de la piel.

Nota 5: Ver capítulo 8: La otra historia. subcapítulo 8.1.

Volviendo a los fármacos con talidomida que habrían circulado en el Perú durante la época del escándalo farmacológico y años posteriores, lo que más llama la atención es la versión de que el Softenil y el Sedalis eran píldoras para dormir -precisamente la misma característica de otros fármacos como el Contergan - y el Enterosediv es -o era - un medicamento para los desarreglos estomacales que al parecer estuvo en circulación hasta hace pocos años, según consta en testimonios de personas que dijeron conocerlo y haberlo tomado. Eventualmente, un familiar de quien escribe comentó que una vez le recetaron el Enterosediv allá por el año 1967, mientras que una amiga doctora dijo también haber visto este mismo remedio en una botica cercana al hospital Cayetano Heredia, en el distrito limeño de San Martín de Porres, en su época de estudiante de medicina, hace unos 12 años (1990). Fue una casualidad que la misma amiga doctora nos dijera esto, toda vez que en cierta ocasión le mostramos el reportaje de la revista LIFE de 1962, donde reconoció el nombre del Enterosediv, mostrándose desde luego muy sorprendida de verlo en una publicación de hace 40 años, señalando además que este mismo medicamento estaba contraindicado para mujeres embarazadas en el Ecuador.

\section{2. ¿Quién explica este desaguisado?}

Ahora, lo que queda por aclarar es el porqué, a pesar de la prohibición de la talidomida durante al menos tres décadas, fármacos con este letal principio activo continuaron circulando, no sabemos cómo, en nuestro país (Perú), sin que las autoridades hicieran o dijeran algo al respecto. O si lo hicieron, ¿dónde rayos está la información que lo corrobore o lo rechace? Ésta simplemente no existe o ha desaparecido, al menos dentro del ámbito del Ministerio de Salud de Perú en Lima. 
Es más, ¡en las bases de datos del CENAFIM/DIGEMID no hay ni rastro de tal información! Sin embargo, hemos encontrado evidencias de que dichos datos sí existieron alguna vez y estuvieron bien guardados en los estantes y ficheros de la Biblioteca del Ministerio de Salud en su sede de la avenida Salaverry, en el distrito del Cercado de Lima, ambiente otrora abierto a la investigación histórica y bibliográfica sobre la salud en el Perú, el mismo que ahora ya no existe, o al menos una parte de su valioso acervo documental. Por ello nuestra desconcertada insistencia en solicitar información sobre el pasado reciente de nuestra historia farmacológica.

A pesar de todos nuestros justificados requerimientos, las autoridades sanitarias actuales, particularmente las del Ministerio de Salud (23) a través del DIGEMID (23a) y el CENAFIM (23b), en su pertinaz desinformación, niegan tener datos sobre la talidomida en nuestro país en décadas pasadas e insisten en desconocer la existencia de los medicamentos citados arriba y/o su principio activo en las farmacias limeñas durante muchos años. Más bien da la impresión de que el propio sistema de sanidad nacional se hubiera vuelto amnésico o que la información sobre aquellos hechos escandalosos haya sido "borrada", perdida o extraviada, no sabemos si de forma casual o adrede, de los anales de la historia peruana reciente. (Nota 6)

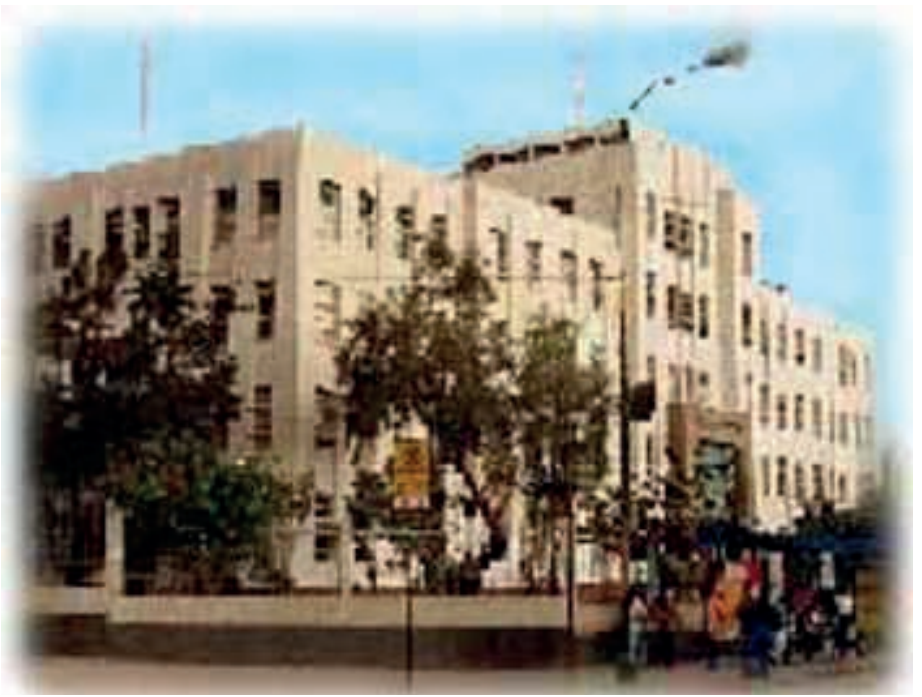

Imagen 14. Foto: minsa.gob.pe Composición fotográfica de la fachada principal del Ministerio de Salud del Perú, en Lima. 
De primera mano, las únicas pistas encontradas -hasta la fecha - de la talidomida en el Perú han sido los valiosos testimonios, aunque muy dispersos, recogidos de diversas fuentes, instituciones y personas que la conocieron y la recordaban, y lo mencionado por la revista LIFE en español del 17 de septiembre 1962, la misma que, no sólo cita los nombres de dichos fármacos, sino que habla de la existencia de casos de malformaciones talidomídicas en el Perú cuando dice que: "En Perú, donde la droga fue prohibida en junio pasado -no detalla el nombre o nombres de los fármacos vetados-, se informa que en el mes de agosto han ocurrido dos casos". Contradictoriamente, ni en las bases de datos del DIGEMID / CENAFIM, ni en las del Ministerio de Salud, ha sido posible encontrar mayor información sobre aquella "prohibición", y mucho menos los nombres de los medicamentos involucrados en ello, lo que, por cierto, causa mucha sorpresa.

De ser verdad lo mencionado líneas arriba, y al no existir una voluntad positiva por parte de las autoridades responsables del Sector Salud peruano que ayude a replantear este absurdo "silenciamiento" de nuestra historia sanitaria reciente (ó mejor dicho, nuestra historia farmacológica reciente), lo más probable es que dicha "amnesia colectiva" de hechos que sucedieron recién, a la vuelta de la esquina, se deba a la mano negra o irresponsable de una persona o un grupo de personas interesadas en que no se conozca la verdad o verdades sobre nuestro pasado farmacológico reciente: hay alguien en el sector Salud peruano que parece estar muy interesado en ocultar o esconder una información a todas luces importante. ¿De qué otro modo se puede explicar, entonces, esta mudez institucionalizada? En el Ministerio de Salud del Perú existe ahora una "Oficina de Comunicaciones", según consta en su organigrama institucional consultado a través de Internet. Aunque se supone que éste es el órgano que vincula al Sector Salud con los medios de comunicación o de prensa, en realidad no es otra cosa que una oficina de relaciones 
públicas encargada de preocuparse más por la "imagen institucional" que por otra cosa. Dicho portafolio ministerial tiene también una "Oficina de Estadística e Informática" que cuenta con datos proporcionados en su mayor parte por el Instituto Nacional de Estadísticas e Información (INEI) (72), y otras organizaciones relacionadas con la salud pública. Sin embargo, aquí (Nota 5a) no hay ni rastro de un "Centro de Información" o, mejor dicho, una biblioteca, que sabemos existía antes de la administración fujimorista (ver Nota 6), la misma que por cierto dejó muchos forados -y muy grandes- tanto en las arcas fiscales como en la conciencia moral de los peruanos.

Y mientras esta indiferencia "oficial" -y solapada- sucede, y ha sucedido, siguen naciendo niños con malformaciones talidomídicas en la selva amazónica peruana y brasileña, amén de otros lugares en los países más pobres del planeta -si nos atenemos a los hallazgos de un grupo de investigadores británicos que viajó en dos oportunidades a Sudamérica para corroborar unos extraños rumores y versiones sobre niños sin piernas o sin brazos entre las poblaciones selváticas, cuyos trabajos encontraron eco en el portal Thalidomide.org (ver capítulos 8 y 9 del presente informe). Una realidad que sorprendentemente es negada por las autoridades peruanas, pero que parece constar su veracidad. Todo parece indicar que en cualquier momento, en el menor despiste, puede ocurrir otra desgracia, como ya ha sucedido en el pasado... o está sucediendo ahora.

Ciertamente no hemos escatimado nada para indagar en el Centro Nacional de Farmacovigilancia e Información de Medicamentos CENAFIM, una dependencia de la Dirección General de Medicamentos, Insumos y Drogas del Ministerio de Salud del Perú, pero, por increíble que parezca, tanto su jefa, la Químico Farmacéutica Susana Vásquez, como otros funcionarios de esta institución, han insistido, tal como aparece citado en la carta transcrita al comienzo de este trabajo, que el principio 
activo talidomida "no se encuentra registrado en el país". Es más, la mencionada funcionaria indicó que las bases de datos de su institución sólo tenían registros de fármacos, drogas y sustancias químicas ¡desde 1987!, vale decir, para ellos todo lo que sucedió antes de ese año... simplemente nunca existió.

Lo paradójico del asunto es que, mientras la Dra. Vásquez persiste en su afirmación de que la talidomida no se encuentra registrada en el Perú -luego ella misma entraría en contradicción de una manera por lo demás sospechosa (como se puede ver en el capítulo 19. Epílogo III: Noticia de última hora... ¿Se retracta la doctora Vásquez?)como principio activo, y encima peligroso, en otras informaciones, la mismísima institución donde ella labora, vale decir, el DIGEMID, parece desmentirla..., si no recomendamos visitar los boletines de fármacos del DIGEMID, donde el lector podrá observar que no andamos tan descaminados, los cuales mencionan la talidomida cuando hablan de compuestos químicos de riesgo.

Este boletín institucional llamado Fármacos tiene asimismo noticias de la Revista Panamericana de Salud de la OPS (24), que también ha mencionado la talidomida en reiteradas ocasiones. Resulta sorprendente constatar que, a pesar de las afirmaciones negativas de la Dra. Vásquez, entidades internacionales tan prestigiosas como la Organización Panamericana de la Salud mencionan en sus medios de divulgación médica un principio activo (talidomida) que (¿?) no aparece registrado en bases de datos farmacológicos tan importantes como lo es "PERUDIS" que, dicho sea de paso, parece que necesita con urgencia un baño de ruda...

La verdad es que desde estas páginas quiero expresar mi desconcierto y decepción. Sinceramente no sabemos quién le está mintiendo a quién -si vemos, valga la reiteración, lo mencionado en el capítulo 19. Epílogo III: Noticias de última hora... ¿se 
retracta la doctora Vásquez?-, pero las evidencias están aquí y, ciertamente, con actitudes burocráticas y evasivas de parte de funcionarios públicos como los del CENAFIM sólo conseguimos retroceder como personas y como sociedad. Y pensar que esto suceda en nuestro propio país (Perú), de parte de un organismo público de sanidad que, se supone, está allí para servir a la comunidad, preocuparse por la salud de millones de personas y responsabilizarse en proporcionar información objetiva y veraz, en vez de aplicar una velada desinformación -algo que no va con el espíritu de la nueva política aperturista del gobierno peruano de turno-, francamente, es algo que avergüenza. (25) (Nota 6a)

Nota 5a: Salvo la biblioteca del Centro de Documentación de la OPS/OMS filial Perú, ubicada en el primer piso de dicho ministerio, la misma que tiene también una base de datos bibliográfica en línea con información que data de 1980, que puede ser consultada por Internet a la siguiente dirección: http://www.per.ops-oms.org/, aunque no hay referencia alguna sobre el término talidomida ni sobre sus secuelas.

Nota 6: Cabe recordar que durante la corrupta gestión del presidente Alberto Fujimori (1990 - 2000), las bibliotecas y centros de información de muchos ministerios y organismos estatales fueron desactivados, o literalmente saqueados, sobre todo aquella información acumulada a 1990, la misma que, misteriosamente, se "evaporó" sin explicación alguna, por lo que desaparecieron bibliotecas y hemerotecas enteras, y con ello se perdió la memoria reciente de la administración pública y gran parte de la historia peruana del último medio siglo. En la biblioteca del Ministerio de Salud se perdieron obras antiquísimas sobre medicina y registros de sanidad acumulados desde la creación de este ministerio (1935) hasta fechas recientes. Sugerimos visitar la reseña histórica de este ministerio en: 
http://www.minsa.gob.pe/ministerio/historia/donde el lector podrá apreciar que no hay mucha información cronológica que digamos, salvo la que atañe a la "imagen institucional".

(Nota de Vivat Academia: ¿No les recuerda esto a los lectores el proceder del Gran Hermano en la novela de Orwell: "1984"?)

Nota 6a: Para ampliar detalles sobre este polémico asunto recomendamos al lector ver el Epílogo III, capítulo 19, epígrafe 19.1. Noticia de última hora...¿Se retracta la doctora Vásquez?

\section{La crisis en el país más seguro del mundo...}

En Alemania, la talidomida fue retirada del mercado en noviembre de 1961; en Inglaterra, en diciembre de ese mismo año y, en Canadá, en marzo de 1962. En la mayoría de los países latinoamericanos, las ventas fueron suspendidas oficialmente al hacerse públicos los terribles efectos de la droga. Pero ya el daño estaba hecho (Ver cuadro de abajo). Si bien en Estados Unidos el medicamento Kevadon nunca fue aprobado por la FDA, se sabe de madres estadounidenses que lo adquirían vía Europa, Canadá, México, o en el mercado negro, o les llegaba como muestras médicas de las "píldoras experimentales" distribuidas a los médicos por el fabricante norteamericano Merrell. 


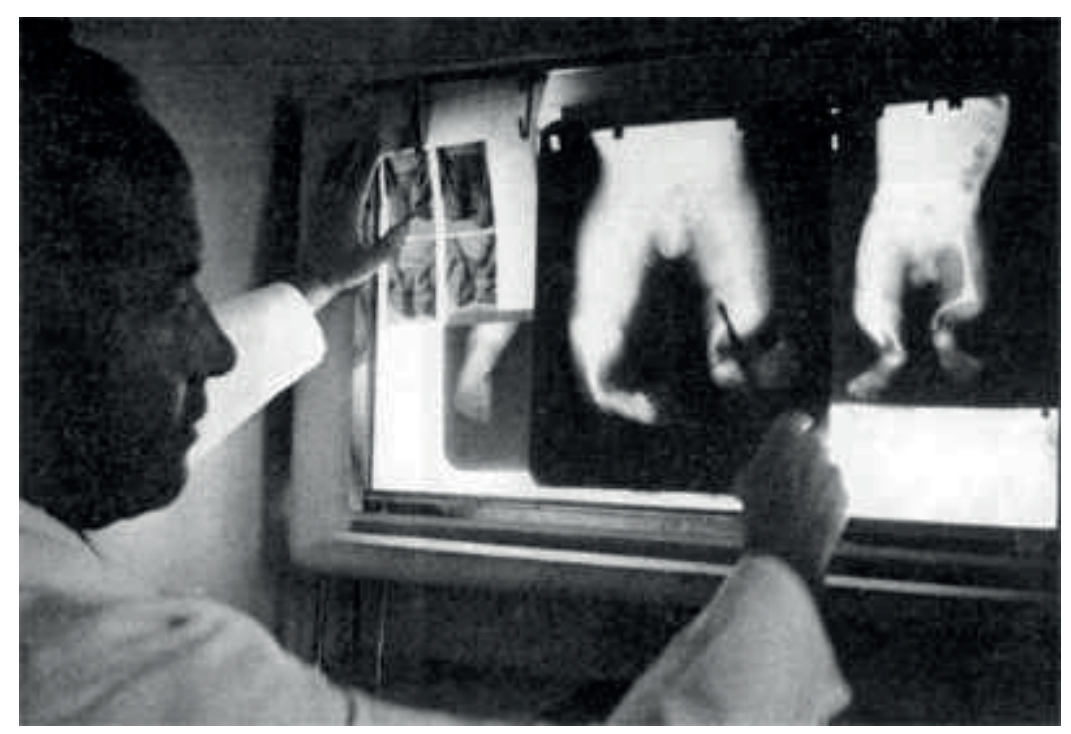

Imagen 15. Foto Revista LIFE en español

"Analizando el daño. El Dr. Oskar Hepp, director de un hospital de Munster, Alemania -que proporcionará miembros artificiales para unas 250 víctimas de la talidomida - estudia las radiografías de piernas lisiadas; otras anomalías típicas incluyen orejas deformes y una mancha roja en la frente." Leyenda publicada por LIFE en español. 

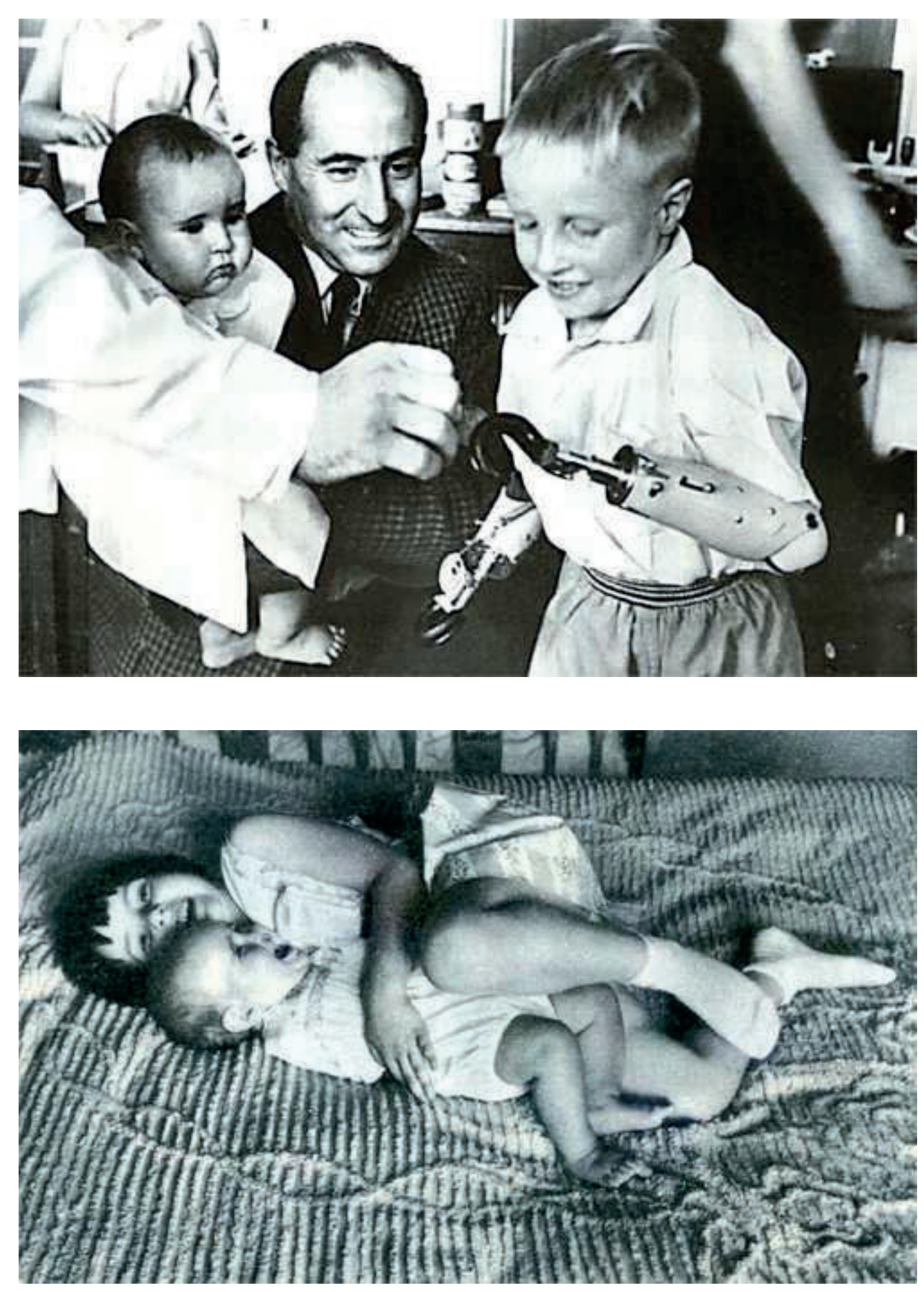

Imágenes 16a. -- 16b. Fotos LIFE en español

Foto 16a (izquierda)."Familia unida. Los Satherly recibieron con cariño a su bebé. Su hermana lo abraza -foto $16 \mathrm{~b}$ (derecha) - y su padre lo lleva a un hospital para 
estudiar el uso de miembros artificiales." Leyenda publicada por la revista LIFE en español.

Una de las madres que vivieron esta tragedia, cuenta la revista LIFE, era Sherri Finkbine. Ella, a punto de dar a luz, había tomado la droga Kevadon durante el embarazo por lo que se sentía atrapada por la incertidumbre, presa de angustiosos problemas éticos y morales. Como en su país estaba prohibido el aborto, llevó su caso ante un tribunal con la idea de lograr la anuencia judicial para poder someterse a una interrupción quirúrgica de su embarazo. Sin embargo, un juez de Phoenix terminó rechazando su solicitud de legalizar el aborto para poder deshacerse del hijo que llevaba en sus entrañas. "Los padres de los niños que habían nacido deformes -relata la revista LIFE - , probablemente más de 5.000 hasta la fecha (1962), estaban también acosados por las dudas. Algunos de ellos, incapaces de soportar el dolor, pensaron que sus hijos debían ser eliminados misericordiosamente. Pero la mayoría, echando mano de las grandes reservas de amor y de ánimo que suelen tener los padres, miraron hacia el futuro tratando de allanarles el camino a sus hijos." 


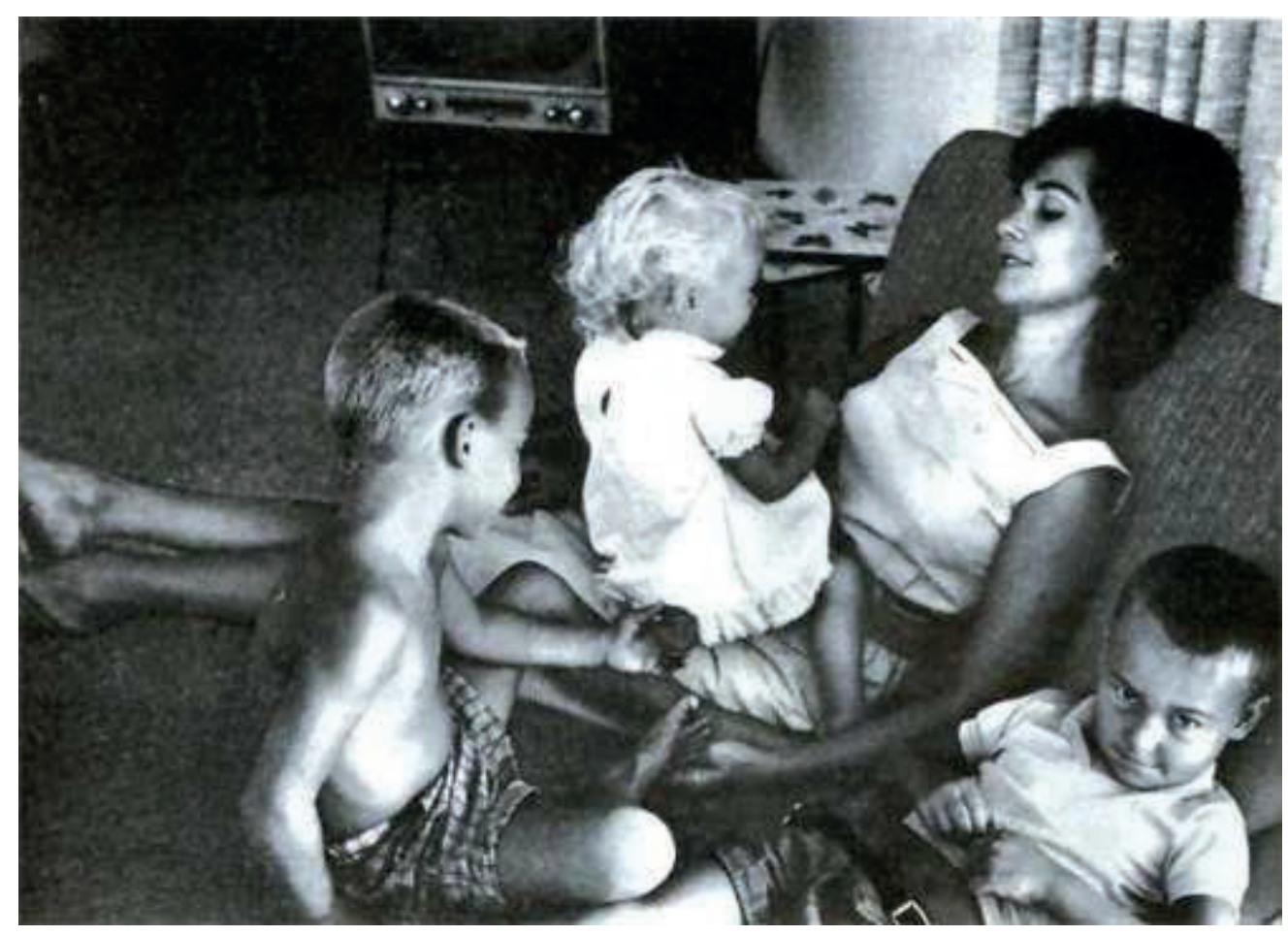

Imagen 17. Foto: Revista LIFE en español

Esperando el fallo. "Acompañada de sus hijos, Sherri Finkbine espera el fallo del juez. Con ella están Mark (izquierda) de 6 años, Steve, de 4, y Tracy, de 20 meses. El cuarto hijo había ido de visita". Finalmente tuvo que resignarse a tener su hijo con las secuelas de la talidomida.

La realidad americana escapaba, pues, a lo imaginable. Ellos, el país más seguro del mundo, sufrían en carne propia la misma tragedia que se había vivido en Europa. Y con ellos, otras decenas de miles de familias en todo el mundo tuvieron que afrontar una situación parecida. Pero la vida continuaba y la tragedia también. Aunque en 1961, la OMS (26) prohibió por completo la fabricación y comercialización de la droga, la farmacéutica alemana Chemie-Grünenthal continuó elaborando la talidomida, pero para combatir otras enfermedades como la lepra (Nota 7), todo gracias a un curioso descubrimiento.

Nota 7: Ver Capítulo 8: La otra historia, subcapítulo 8.1. 


\section{Las víctimas "oficiales" y las otras...}

No hay acuerdo sobre la cantidad de víctimas que provocó la talidomida a nivel mundial. Mientras unas fuentes mencionan 10 mil a 15 mil los bebés malformados por culpa de la droga, otras dicen que fueron 20 mil y más. Lo cierto es que esta tragedia farmacológica atacó tanto a países desarrollados como en desarrollo, pero nunca se conocerán cifras exactas de ello debido a que el medicamento fue consumido indiscriminadamente en países donde no había control farmacológico. La publicidad de los fabricantes de la talidomida contribuyó a esta difusión masiva.

Si bien hay unas estadísticas "oficiales", que sólo parecen reconocer a las víctimas indemnizadas por el fabricante de la talidomida (Chemie-Grünenthal), lo cierto es que muchas de éstas no toman en cuenta a los bebés malformados que nacieron en otras naciones europeas, y especialmente en los países más pobres, que por diversos motivos no pudieron reclamar una reparación monetaria por el daño causado. "En Alemania y Gran Bretaña se establecieron fondos, pagados por las compañías responsables y el Estado -cuenta José Riquelme en su libro "Hijos de la talidomida" , a fin de reparar en lo posible el daño causado a las víctimas de la Talidomida. Treinta y ocho años después, algunas cuestiones legales están todavía sin resolver en diversos casos. Hace pocos años, el Sunday Times, ganaba, por fin, en la Corte de los Derechos Humanos, su largo contencioso contra la compañía Distillers (el laboratorio fabricante del Distaval) y contra la Cámara de los Comunes que prohibió la publicación en el Reino Unido de un reportaje sobre los niños de la Talidomida en 1972."

"Las sumas compensatorias pagadas a los niños en Alemania -relata el libro de Riquelme - se remontan a unos 25.000 marcos y entre 100 y 450 marcos al mes en concepto de renta vitalicia como minusválido. Unas 925.000 Ptas. en concepto de 
indemnización y 16.650 Ptas. equivalentes al ingreso mensual aproximado. En Inglaterra, se pagó a los padres (de las víctimas) 5.000 libras, más una parte proporcional de 6 millones de libras, para ser repartidos entre los 342 beneficiarios entonces acogidos a dichas compensaciones. O lo que es lo mismo, 700.000 Ptas. como indemnización, y, aparte, 2.701.754 Ptas. entregadas a cada beneficiario inglés. (Todos estos valores y cifras, están basados en los cambios oficiales de divisas del día 25 de marzo de 1980)."

Para entregar dichas indemnizaciones, el gobierno alemán creó la Fundación "Hilfwerk für Behinderte Kinder", (Auxilio a niños impedidos), (67) "para ayudar y asesorar a todas estas personas, que habían sido víctimas de los devastadores efectos del fármaco, en todos los países del mundo" -prosigue el libro-. Esta era la organización encargada de canalizar las peticiones de los afectados para que pudiesen acceder a todas estas rentas e indemnizaciones. Se había fijado el 31 de diciembre de 1983 como la fecha límite para todo proceso legal de reclamaciones económicas. "Para obtener la indemnización, las víctimas de la Talidomida, o los familiares de éstos, tenían que aportar diversa documentación. También debían demostrar igualmente el nombre del médico que había prescrito el fármaco, con su número de colegiado correspondiente. E incluso el mismo médico, debía acreditar y certificar que había recetado el fármaco. Había incluso que acreditar el lugar donde se compró el medicamento, aportar radiografías, fotografías... etc., etc..." -explica el autor de "Hijos de la talidomida". 


\section{Contergan läßt grüßen!}

\section{Der Skandal ohne Ende}
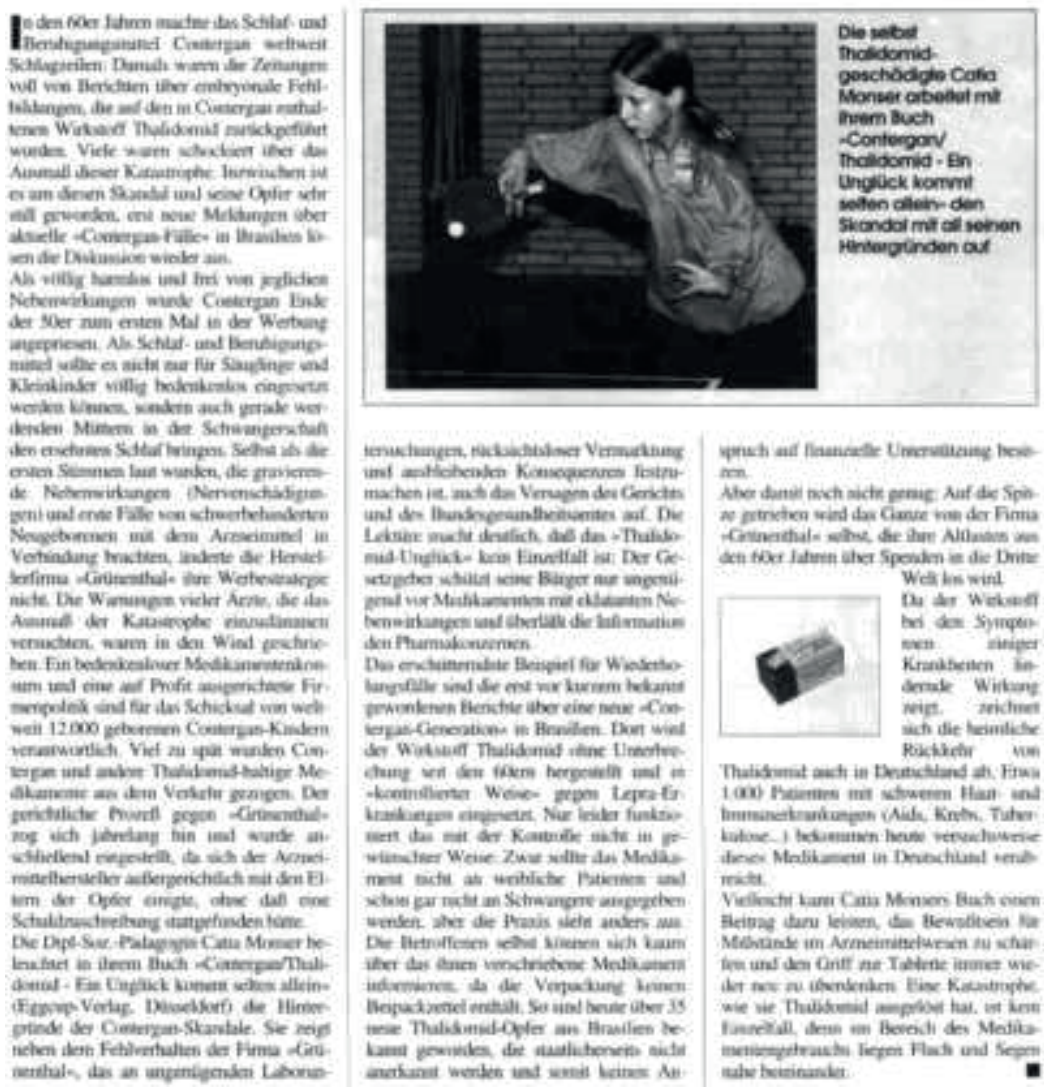

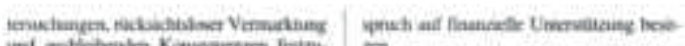

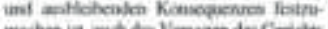

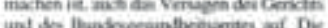

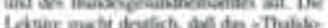

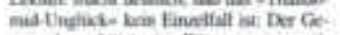

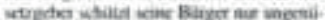

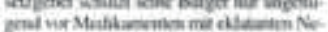

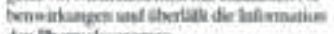

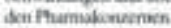

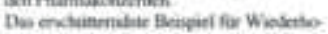

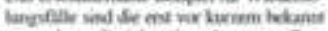

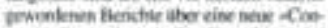

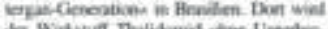

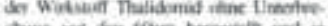

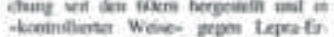

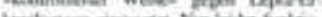

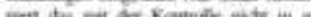

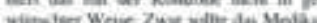

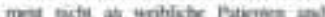

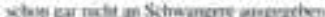

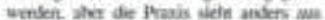

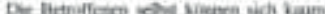

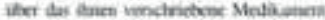

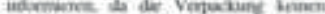

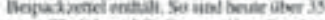

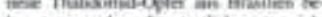

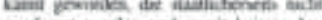

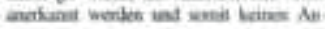

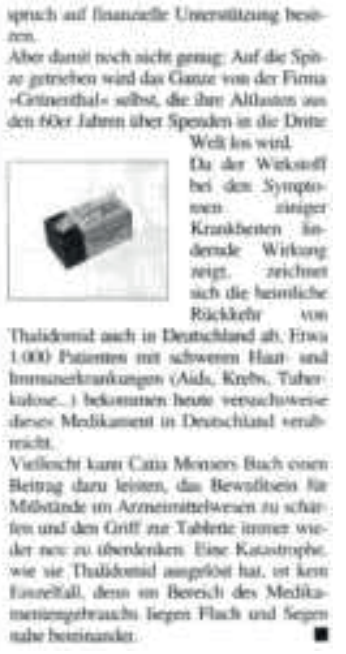

Imagen 18. Foto: Herzlich Willkommen Belm Eggcup-Verlag/Rezensionen Buch Monser. "Contergan Läbt Grüben!" - El escándalo en la prensa alemana de la época.

Desgraciadamente, no todas las víctimas de la talidomida tuvieron la misma suerte... a unos afectados "se les pasó" la fecha límite dada por el gobierno alemán para poder reclamar una compensación, incluso en países como España o Canadá, mientras que a otros, aún en la misma Alemania, no pudieron demostrar que eran "hijos de la talidomida" por falta de pruebas o porque los médicos que habían recetado la droga a sus madres se negaron a colaborar "por temor a posibles represalias", como señala el autor del libro. 
Aquel medicamento promocionado como "un novedoso y eficaz remedio, contra las náuseas y molestias propias de los primeros meses del embarazo" iba a cambiar de golpe miles de vidas. "En el mundo se vendieron 310 millones de dosis en los cuatro años que estuvo en el mercado" -escribe Riquelme cuando recuerda aquella época que dejó secuelas tanto a él como a decenas de sus compatriotas (Nota 8). "Es de imaginarse que tal cantidad debe ser cierta, a juzgar por los índices de productividad de los fabricantes de la droga en sus diferentes variantes. De las miles de víctimas de este fármaco -cuenta Riquelme -, sólo sobrevivieron unos cinco mil, repartidos entre Alemania Occidental -unos dos mil quinientos -, Gran Bretaña 430, 200 en Japón y los demás de diversos países tan lejanos unos de otros como Brasil, Australia, Francia, España..." Las cantidades son naturalmente aproximaciones.

Nota 8: Se estima en unas 300 las víctimas de la talidomida en España, aunque es muy difícil encontrar una cifra más exacta. De éstas, solo una minoría fue compensada por Chemie-Grünenthal y el gobierno alemán.

\section{La otra historia}

\subsection{La OMS, el mejor cliente de Chemie-Grünenthal}

En 1965, Jacob Sheskin, un dermatólogo judío, reportó una sorprendente observación, cuando quiso utilizar la talidomida como sedante en cuatro pacientes que sufrían eritema nodoso lepromatoso (ENL), una complicación inflamatoria aguda de lepra lepromatosa. Entonces, para su sorpresa, vio como las lesiones mejoraban en pocas horas. Con ello, la talidomida retomó el interés científico como una droga inmunomoduladora.

Sin duda alguna, la talidomida se salvó del ostracismo total precisamente gracias a este descubrimiento, con una aplicación posterior en otras condiciones inflamatorias parecidas al ENL, como son el lupus eritematoso discoide y úlceras aftosas en 
pacientes con síndrome de inmunodeficiencia adquirida (SIDA). Así se supo que la talidomida ejercía un efecto efectivo en padecimientos dermatológicos; con disregulación inmunológica. Debido a que ejerce su principal efecto antiinflamatorio sobre piel y mucosas.

El descubrimiento de Sheskin no sólo cambió la historia de la talidomida sino que también la reivindicó, a pesar de su negro pasado, además de abrirle las puertas a mercados insospechados, a pesar de estar por aquellos años en la lista negra de la OMS. Según "A 40 años después del holocausto de la talidomida", una crónica publicada hace poco en el portal sueco Thalidomide.org (27), una cadena de televisión británica denunció en 1993 -¡hace 9 años! - que "Chemie-Grünenthal todavía obtiene beneficios con la talidomida", en referencia al supuesto negociado realizado por la Organización Mundial de la Salud que, desde de 1965 hasta la década de los noventa, habría estado adquiriendo grandes lotes de talidomida a la mencionada fábrica alemana, para distribuirla en las selvas amazónicas peruana y brasileña como fármaco contra la lepra, resaltando además que todavía siguen naciendo niños con focomelia por culpa de la actuación de este organismo mundial, tanto en Sudamérica como en otras regiones pobres del planeta.

Para comenzar, el informe señala que tras el escándalo de la talidomida de hace cuatro décadas, "Chemie-Grünenthal ha adoptado un perfil bajo (sic), hasta el punto de que sólo se conoce de ella una referencia postal de su oficina central en Alemania, bajo la dirección: Chemie-Grünenthal GmbH, Zieglerstr 6, 52078 Aquisgrán, Alemania. Y continúa diciendo que esta empresa sigue siendo un productor de la droga" (Nota 9). La misma publicación menciona asimismo la contradicción existente sobre este caso, precisamente cuando se decía que la fabricación y venta de la talidomida estaba vetada: "Cuando la droga fue prohibida por la OMS en 1961, la cadena de producción (de Chemie-Grünenthal) pareció volverse silenciosa. Sin 
embargo, tras el descubrimiento fatal de Sheskin en 1965, la OMS envió una oferta a la farmacéutica alemana para reiniciar la producción de la talidomida..."

Nota 9: A pesar de la apreciación de que "Chemie-Grümenthal ha adoptado un perfil bajo", encontramos su página web:

http://www.grunenthal.com

\section{2. ¿Hubo o hay niños víctimas de la talidomida en la selva peruana?}

Según la misma fuente, como ya se había señalado, en los años siguientes a 1965, la Organización Mundial de la Salud se convirtió en un cliente confiable de la farmacéutica alemana, al comprarle la talidomida para utilizarla en "la guerra contra la lepra". Pero la realidad parece indicar algo más que una simple labor humanitaria en las selvas amazónicas. Al menos esto fue lo que trató de dar a entender el equipo de Yorkshire TV (28) -The British First Tuesday Team Uk-, cuando realizó una expedición a Sudamérica dirigida por el productor James Cutler, quien presentó en 1993 un impactante reportaje sobre la talidomida, titulado: "La droga que volvió" (29), en cuyas imágenes se veía a niños selváticos amazónicos con evidentes secuelas de la sustancia. Durante sus indagaciones sobre el terreno, los productores del referido documental tuvieron acceso, paradójicamente, a informaciones de ChemieGrünenthal sobre las tarifas de producción de la compañía, que ellos facturaban a la OMS por su talidomida.

"En las imágenes presentadas por la emisora de televisión británica -refiere el informe-, se puede apreciar que actualmente hay un uso extenso de la talidomida en países occidentales, así como países en vías de desarrollo", remarcando además que las exportaciones de Chemie-Grünenthal llegan a 47 países. Yorkshire TV señala también que hay una lista donde se establece que países como Marruecos, India, Malí, Surinam y Perú muestran un grave riesgo de nuevos casos de bebés afectados 
por la talidomida. En dicha lista (ver cuadro de abajo) aparecen datos estadísticos sobre la producción total de talidomida vendida por Chemie-Grünenthal a la OMS y repartida por cada país entre los años 1985 y 1992.

En coincidencia con lo señalado por el portal Thalidomide.org, el matutino austriaco Der Standard (30) reportó el 7 de marzo de 1996 "que hay bebés malformados por la talidomida en la India. Y según informaciones confiables, que recuerdan los casos suecos de la talidomida -prosigue el mismo medio-, un estudiante de medicina británico dijo haber visto a un cierto número de niños afectados por la talidomide en la ciudad de Pucallpa (una ciudad peruana conocida por sus numerosos casos de lepra) (30a) durante sus prácticas como voluntario a finales de los años '80". La noticia termina diciendo que "las autoridades en Perú han negado la existencia de niños afectados por la talidomida en este país."

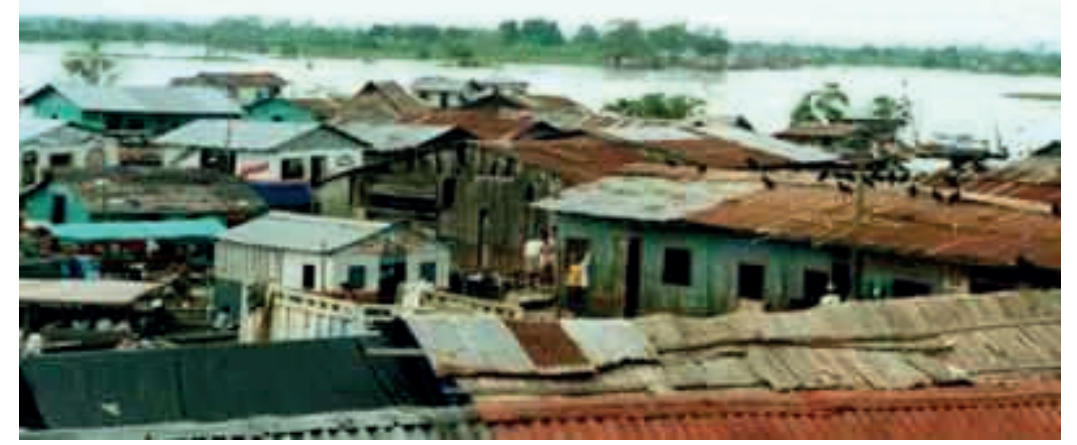

Imagen 19. Foto de Leslie Taylor (Raintree Nutrition, Inc.)

Una villa entre la selva y el agua. La ciudad de Pucallpa es un pintoresco puerto fluvial a orillas del río Ucayali, un tributario del Amazonas. He aquí una sugestiva vista panorámica de esta localidad peruana. 


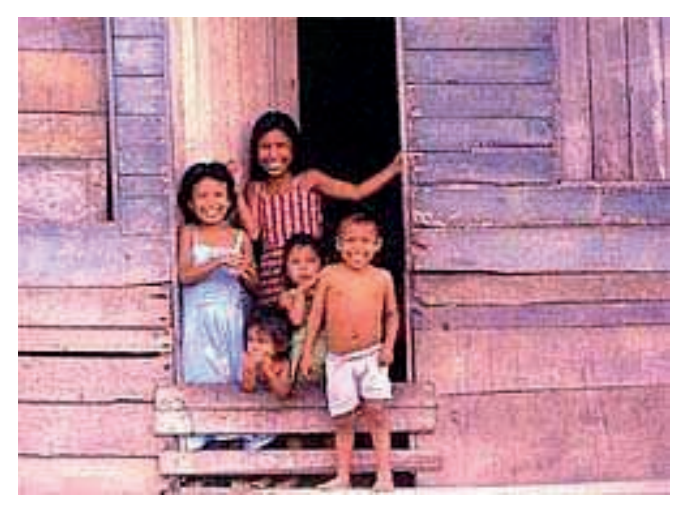

Imagen 20. Foto: Société des Missions Étrangères / Nos Destinations Pérou

Niños de un asentamiento humano de Pucallpa. Esta ciudad es conocida como la puerta de la amazonía peruana; aquí vive una gran población joven sobre la cual se ha cebado la lepra.

Aún así, los rumores parecían brotar de la selva amazónica peruana y llegar hasta Europa y Estados Unidos, y terminaron llamando la atención, toda vez que esta zona es una de las preferidas para los practicantes de medicina norteamericanos, alemanes, franceses e ingleses, quienes suelen venir a pasar largas temporadas en las localidades selváticas y tienen la ocasión de mezclarse con la población aborigen más necesitada y empobrecida del país, y apreciar lo que las autoridades sanitarias se niegan a ver. Y de seguro, el aspirante a médico británico del que habla la crónica de Thalidomide.org no ha sido el único en descubrir estos casos y se atrevió a hablar de ello. Su versión de los hechos, por cierto, interesó a los productores de Yorkshire TV en su país de origen... y la noticia trascendió por todo el mundo. 


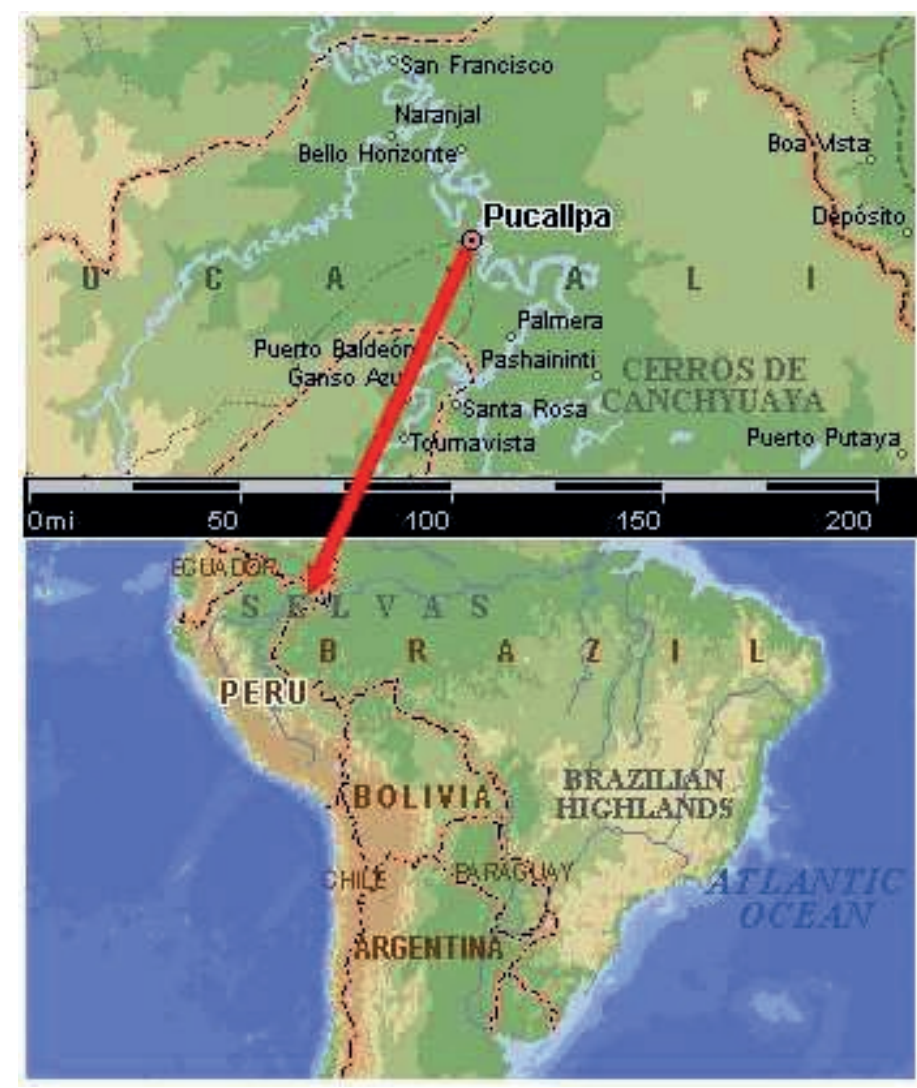

Imagen 21. Ilustración de ECLAMC/Thalidomide.org

"Se han visto numerosos niños afectados por la talidomida en Pucallpa, una ciudad peruana conocida por ser un área endémica para la lepra lepromatosa".

Fuente: ECLAMC / Thalidomide.org

Producción total de talidomida vendida por Chemie-Grünenthal entre 1985 y 1992

\begin{tabular}{|c|c|}
\hline País & $\begin{array}{c}\text { Número de tabletas } \\
\text { de talidomida por país }\end{array}$ \\
\hline Austria & 1600 \\
\hline Bélgica & 1000 \\
\hline Bolivia & 20.000 \\
\hline Bulgaria & 4.900 \\
\hline Cabo Verde & 10.000 \\
\hline Checoslovaquia & 3.600 \\
\hline
\end{tabular}




\begin{tabular}{|c|c|}
\hline Comores & 10.000 \\
\hline
\end{tabular}

\begin{tabular}{|c|c|}
\hline Cuba & 39.300 \\
\hline Chipre & 20.000 \\
\hline Dinamarca & 29.600 \\
\hline Etiopía & 15.000 \\
\hline Finlandia & 10.400 \\
\hline Alemania & 141.400 \\
\hline Grecia & 65.000 \\
\hline Haití & 5.000 \\
\hline Hong Kong & 4.000 \\
\hline India & 316500 \\
\hline Israel & 6.000 \\
\hline Italia & 15.400 \\
\hline Corea & 130.000 \\
\hline Liberia & 25.000 \\
\hline Malí & 60.000 \\
\hline Malasia & 1.000 \\
\hline Marruecos & 400.000 \\
\hline México & 130.000 \\
\hline Nueva Zelanda & 28.000 \\
\hline Países Bajos & 11.500 \\
\hline Pakistán & 10.000 \\
\hline Paraguay & 30.000 \\
\hline Perú & 200.000 \\
\hline Portugal & 20.000 \\
\hline Suiza & 46.900 \\
\hline Singapur & 60.000 \\
\hline
\end{tabular}




\begin{tabular}{|c|c|}
\hline Surinam & 100.000 \\
\hline Suecia & 33.100 \\
\hline Traskei & 5.000 \\
\hline Turquía & 5.000 \\
\hline EE.UU & 155.200 \\
\hline
\end{tabular}

\section{Los niños del Brasil}

\subsection{La embriopatía que llegó del frío}

La investigación periodística de Yorkshire TV se repitió a mediados de la década pasada (1996 - 1997), cuando nuevamente se divulgaron cientos de rumores acerca de la existencia de niños con focomelia en el Brasil, todo esto mientras un grupo de especialistas pediátricos sudamericanos decidió investigar una posible conexión entre la droga y las malformaciones congénitas -embriopatía talidomídica-, de las que se decía iban en aumento en distintos países, sobre todo en las regiones más deprimidas. No sólo encontraron un $100 \%$ de coincidencias entre la talidomida y las malformaciones congénitas derivadas de esta, sino que comenzaron a sospechar de un número extenso de víctimas desconocidas, siendo éstas el 1\% del total de los nacimientos en América del Sur, con la excepción de las áreas rurales. (Ver Tabla al final de este subcapítulo).

Thalidomide.org, en su reportaje titulado: "Children born in Brazil" (Niños Nacidos en Brasil) (31), relata que durante la preparación de su dramática información periodística sobre "La talidomida es un teratógeno actual en América del Sur", James Cutler, el productor del documental de la televisión británica "La droga que volvió" (ver más arriba), les mostró las fotografías que había tomado durante su trabajo en varias localidades brasileñas entre los años 1996 y 1997. Las vistas, donde aparecen niños sin piernas o sin brazos, parecían demostrar que la talidomida ha estado afligiendo a la población infantil y adulta de este país. Estas imágenes -que 
mostramos en el presente reportaje - son presentadas como una denuncia gráfica contra la indolencia de los gobiernos y autoridades sanitarias y un reclamo de ayuda para estas criaturas inocentes, víctimas injustificadas de la talidomida en plena década de los 90.

El mismo informe explica también que los especialistas médicos de ECLAMC (32) habían decidido investigar sobre la talidomida en Sudamérica para corroborar precisamente las noticias propaladas por diversos medios acerca de la existencia de niños con embriopatía congénita, vale decir, la malformación provocada por esta droga. Pero el único trabajo especializado que encontraron sobre este asunto en la literatura científica era un informe sobre casos prenatales en Sâo Paulo, Brasil.

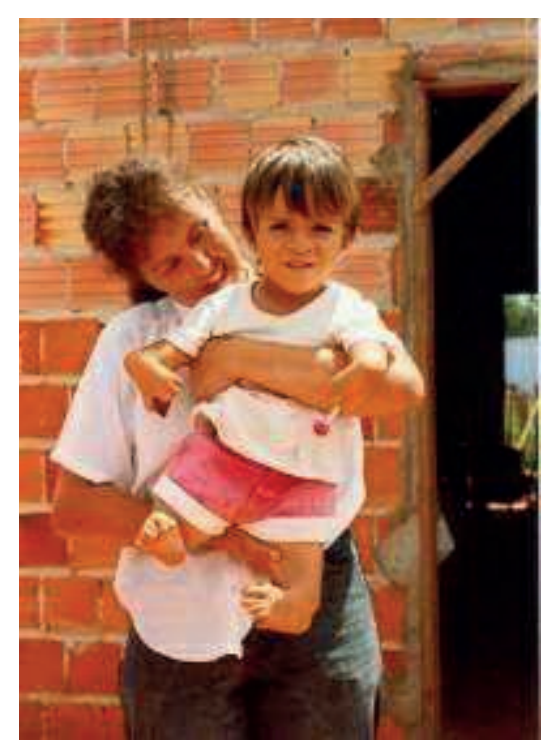

Imagen 22. Foto: James Cutler - Yorkshive TV. UK

Durante su larga estancia en Brasil, el productor James Cutler no podía entender por qué a este pequeño le faltaban brazos en un lugar tan alejado de Europa. Después se enteraría de algo que le erizó los pelos: era la talidomida. 


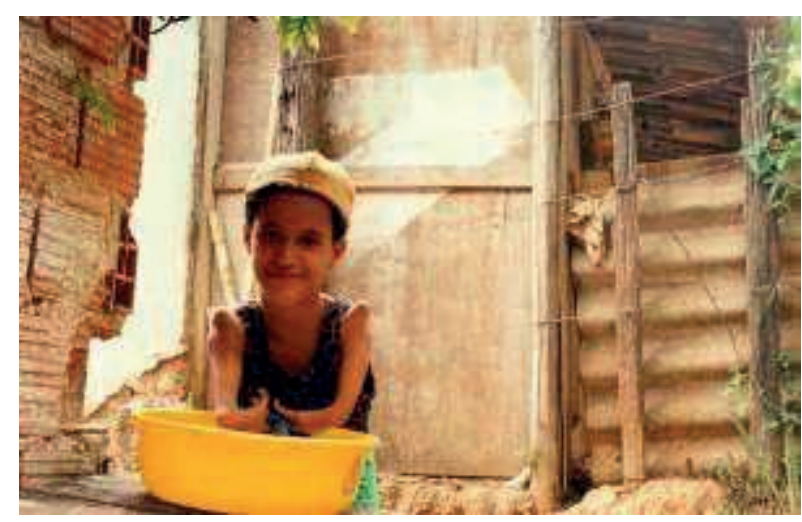

Imagen 23. Foto: James Cutler - Yorkshire TV. UK

La pequeña Jacqueline juega con agua sin preocuparse de su malformación congénita.

"El estudio estaba basado en informaciones proporcionadas por la red de hospitales de maternidad que colaboran con el ECLAMC, una institución médica internacional que agrupa a especialistas en malformaciones congénitas. Para ello se investigó la disponibilidad de talidomida en cada país con el apoyo de los representantes de ECLAMC", -señala el sitio web.

La misma fuente que condujo a descubrir la existencia de talidomida en el país carioca, menciona también los nombres y direcciones postales de fabricantes y distribuidores, los medios para obtener la droga, la marca de fábrica, las posologías y las dosis. Se consideraba que ésta era la mejor manera de obtener esta información, antes de hacer preguntas difíciles a las autoridades sanitarias locales, totalmente reacias a brindar cualquier información a la prensa sobre este peliagudo asunto.

También se solicitó información sobre los casos de malformaciones congénitas o embriopatía talidomídica en nacimientos desde 1965, enviándose la petición a médicos y genetistas del ECLAMC así como a la Asociación Brasileña de Víctimas de la Talidomida ABVT. (33) "Así se encontró la existencia de talidomida en ocho de los diez países de Sudamérica, excepto Chile y Ecuador, a través del tratamiento contra 
la lepra, dependiendo de sus ministerios de salud. Se supo también que en Brasil podía adquirirse la droga comercialmente en algunas farmacias, y que ésta era o es manufacturada en Argentina y Brasil, y exportada a otros países "por debajo de la mesa"'", -concluye el reportaje.

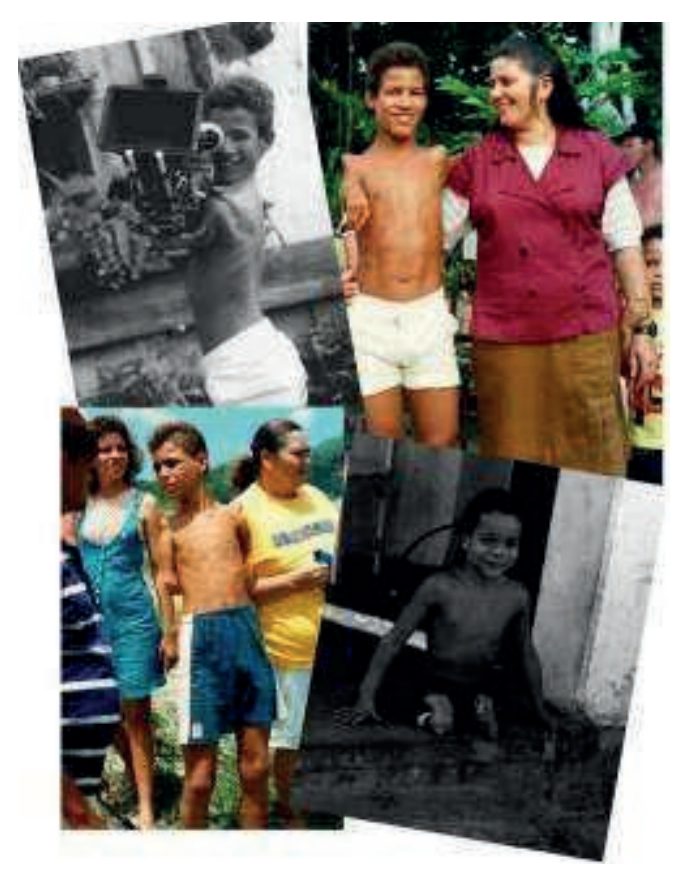

Imagen 24. Foto: James Cutler - Yorkshire TV. UK

Estos son algunos de los niños con los que el equipo de Yorkshire TV se encontró durante sus investigaciones en Brasil: Daniel, Fabio y Hércules.

\subsection{Chicos en crisis}

El estudio de ECLAMC informa que desde 1965 nacieron en Sudamérica al menos 34 niños con embriopatía congénita o malformaciones debido a la talidomida que tomaron sus madres durante el embarazo. Aunque no se ha negado que puedan ser muchos más, el trabajo sólo menciona las malformaciones talidomídicas comprobadas como tales. "Estos 34 casos nacieron entre 1969 y 1995 -indica el trabajo - . Un caso nació en Brasil en 1969, 7 casos en los años setenta, 20 en los años 
ochenta, y 6 en los años noventa. Un caso nació en la ciudad argentina de Córdoba. Y otros 33 casos en 21 ciudades de 9 estados del Brasil."

La misma institución realizó una pormenorizada especificación de los 33 casos brasileños oficialmente confirmados de nacimientos con malformaciones congénitas por culpa de la talidomida, señalando el nombre de la ciudad, la abreviatura del estado y el número de casos entre paréntesis:

Belém, PA (2); Manaus, AM (1); Paulista, PE (2); Salvador, BA (1); Belo Horizonte, MG (4); Itaúna, MG (1); Itaú de Minas, MG (1); Pompeu, MG (3); Ubá, MG (1); la Nova Iguazu, RJ (1); Niteroi, RJ (1); São Paulo, SP (2); Tatuí, SP (1); Campinas, SP (3); Sao José el dos Campos, SP (1); Sertaozinho, SP (1); Ribeirao Preto, SP (1); Piraguara, PR (1); Marandero, PR (1); Curitiba, PR (2); Bagé, RS (1).

Estos lugares de nacimiento fueron trazados en un mapa de Sudamérica. Ver la siguiente ilustración: 


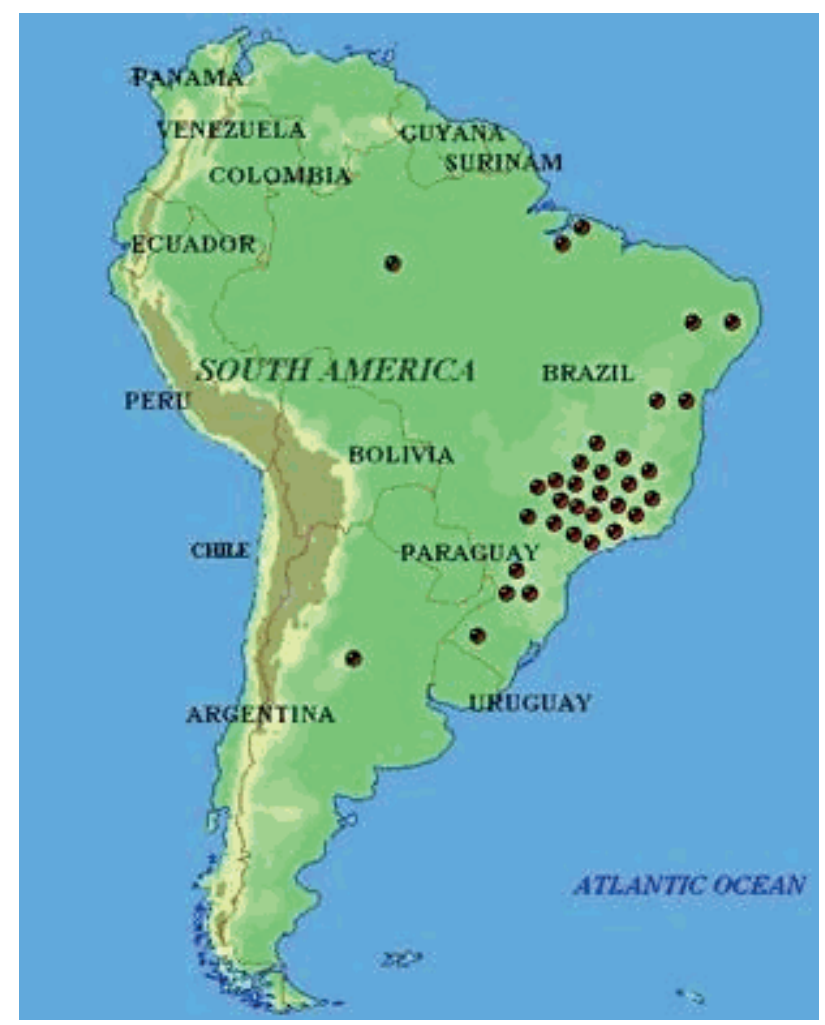

Imagen 25

Este mapa de Sudamérica muestra los lugares dónde los pediatras del ECLAMC localizaron niños afectados por la talidomida. Cada punto representa a un niño.

El continente aparece subdividido por países. En estas áreas geográficas se han representado los puntos de incidencia de casos de lepra como sigue: Alto Brasil (14 por cada 10,000 habitantes), Colombia, Venezuela y Paraguay (3 a 5 por cada 10,000), Argentina, Bolivia, Ecuador, Perú, y Uruguay (alrededor de 1 por cada 10,000), y cerca del cero en Chile. Como se puede apreciar, donde la lepra es común, los casos de niños víctimas de la talidomida son más frecuentes.

Fuente: ECLAMC / Thalidomide.org

\subsection{La lepra, una buena excusa}

Un botón de muestra de esta situación lo encontramos en la ciudad brasileña de Belo Horizonte, en cuya periferia se encuentra FUNES, la "Fundação Ezequiel Dias" (34), 
la mayor manufactura de talidomida de Sudamérica. El estudio de ECLAMC menciona también la sospecha de que en la misma ciudad hay otra manufactura donde se produce la droga, como es el caso de "Tortuga", una compañía zootécnica agraria. (35).

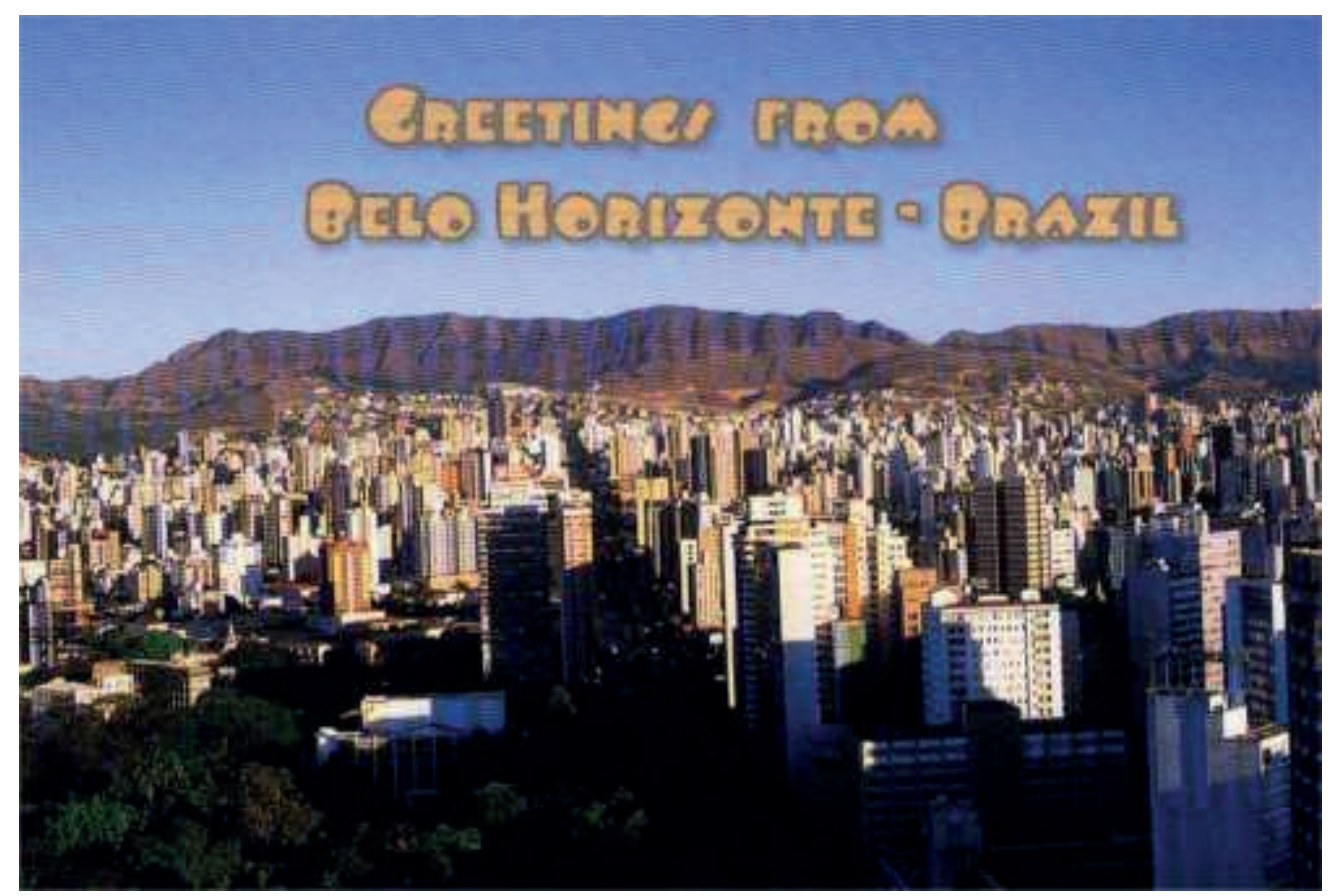

Imagen 26. Foto: Thalidomide.org

En la ciudad de Belo Horizonte se encuentra la mayor manufactura de talidomida de Sudamérica.

No es pues casual encontrar industrias manufactureras de talidomida en una región donde la lepra es endémica. El estudio refiere que en Sudamérica la accesibilidad de la talidomida es proporcional a la frecuencia con que se manifiesta la lepra, encontrándose un predominio máximo de esta enfermedad en Brasil (14 por cada 10.000 habitantes), en comparación con Colombia, Venezuela y Paraguay (3 a 5 por 10.000), y Argentina, Bolivia, Ecuador, Perú y Uruguay (alrededor de 1 por 10.000), y cerca del cero en Chile. 
De todos estos casos, el ECLAMC -institución con la cual no ha sido posible contactar en reiteradas ocasiones- puso a disposición de Thalidomide.org la descripción de diez de ellos, más el de un feto publicado por Gollop (36) en 1987, con el fin de ilustrar la situación. En el artículo los autores dan un resumen de estos once casos. Advertimos al amable lector que algunos pueden ser muy chocantes:

Caso 1. Mujer, nacida en 1971, en Sao José dos Campos, Brasil, de una madre leprosa, medicada con talidomida durante el embarazo. Defectos en los miembros: superior derecho: amelia con retazos de un dedo; superior izquierdo: mano atrofiada, con dos dedos con tres falanges, articulada en el hombro. Ninguna otra anomalía.

Caso 2. Mujer, nacida en 1978, en Córdoba, Argentina, de una madre leprosa de 36 años, medicada con talidomida durante dos años, hasta el octavo mes de embarazo. Defectos en los miembros: superiores: defecto bilateral simétrico con el húmero atrofiado, ausentes cúbito y radio, manos con tres dedos de tres falanges; pierna izquierda: atrofia de fémur y tibia. Otras anomalías: hemangioma plano en la región frontal, IVSD con hipertensión pulmonar. Murió a los siete meses de edad debido a una insuficiencia cardiaca.

Caso 3. Varón, nacido en 1980, en Manaus, Brasil, de una madre leprosa, medicada con talidomida durante el embarazo. Defectos en los miembros: superiores: atrofia bilateral de la cintura escapular con la cavidad glenoidal también atrofiada, huesos cúbito subluxados, subdesarrollo de huesos radio y dedos pulgares, dedos segundo y tercero pegados, desviación del quinto. Ninguna otra anomalía.

Caso 4. Varón, nacido en 1980, en Sertaozinho, Brasil, de una madre leprosa de 32 años, medicada con talidomida durante 8 años y a lo largo del embarazo. Defectos en los miembros: superiores: cavidades glenoidales atrofiadas, hombros rígidos, 
ausencia bilateral de radio y dedos pulgares. Otras anomalías: hemangioma plano en el entrecejo.

Caso 5. Sexo desconocido, nacido el 1986, en São Paulo, Brasil, de una madre leprosa de 24 años, medicada con talidomida desde un año antes de la concepción hasta el trigésimo quinto día de embarazo. Después del diagnóstico, mediante ecografía, el embarazo se interrumpió a las 17 semanas de gestación. Defectos en los miembros: superiores: focomelia bilateral; inferiores: ausencia bilateral de tibia y peroné. Otras anomalías: anosia bilateral (Gollop et al., ' 87).

Caso 6. Varón, nacido en 1988, en São Paulo, Brasil, de una madre leprosa, medicada con talidomida hasta el segundo mes de embarazo; cuando se dio cuenta de que estaba embarazada, ella misma dejó de tomar la medicación. Defectos en los miembros: superiores: defecto bilateral simétrico con ausencia de radio y cúbito corto; inferior derecho: fémur corto, rodilla dislocada, ausencia de tibia, dedo gordo del pie duplicado; inferior izquierdo: ausencia de fémur y tibia atrofiada. Otras anomalías: labio superior abombado; vértebras C1 y C2 fusionadas.

Caso 7. Mujer, nacida en 1988, en Itaú de Minas, Brasil, de una madre leprosa, medicada con talidomida durante 2 años y a lo largo de la gestación. Defectos en los miembros: superiores: ausencia bilateral de dedos pulgares y existencia de un pequeño pedúnculo en la falange proximal del segundo dedo de la mano derecha. Otras anomalías: microsia bilateral de grado III; canal A-V; reflujo gastroesofágico.

Caso 8. Mujer, nacida en 1991, en Campinas, Brasil, de una madre leprosa de 32 años, medicada, durante el primer trimestre de su embarazo, probablemente con talidomida. Defectos en los miembros: superior izquierdo: radio atrofiado; los dedos pulgares de ambas manos con tres falanges. Otras anomalías: hemangiomas planos 
en los párpados, cara y entrecejo; canal A-V; quistes encapsulados en el lóbulo derecho del hígado; crecimiento tisular anormal en los conductos biliares.

Caso 9. Varón, nacido en 1994, en Bagé, Brasil, de una madre leprosa de 28 años, medicada con talidomida durante 7 años y en el primer trimestre de embarazo. Defectos en los miembros: tetra-focomelia bilateral, deficiencias en los dedos de ambas manos, polidactilia preaxial (7 dedos) del pie izquierdo, duplicado el dedo gordo del pie derecho. Otras anomalías: No bajada bilateral de los testículos.

Caso 10. Varón, nacido en 1994, en Campinas, Brasil, de una madre leprosa de 22 años, medicada con talidomida antes de la concepción y durante las primeras 16 semanas de embarazo: $300 \mathrm{mg}$, 3 veces por semana. Defectos en los miembros: tetramelismo preaxial. Superiores: ausencia de radio derecho y atrofia del izquierdo; ambos pulgares pedunculados con ausencia de metacarpianos; inferiores: ausencia bilateral de tibia. Otras anomalías: existencia bilateral de ranuras transversales en los lóbulos de las orejas; hidrocelia derecha.

Caso 11. Mujer, nacida en 1995, en Campinas, Brasil, de una madre leprosa de 22 años; Medicada con talidomida y dapsona en días alternos, durante cinco años. En el momento de la concepción se le administraba talidomida "prn" para el alivio del dolor. El feto presentaba agénesis renal bilateral, diagnosticada mediante ecografía, a las 16 semanas de gestación, interrumpida en la semana vigésimo primera. La autopsia reveló un feto hembra de 16 a 18 semanas con agénesis parcial de tibia izquierda, peroné encorvado y duplicación del pulgar de la mano derecha. Otras anomalías: agénesis renal bilateral y equinovaria bilateral de los tobillos.

La investigación realizada por ECLAMC llevó a informaciones que iban desde el año 1967 hasta antes de 1998, lo que permitió sacar a luz la existencia de la talidomida en las selvas brasileñas, corroborando, asimismo, las versiones sobre la existencia de niños talidomídicos en la amazonía peruana y brasileña, todo esto cuando se suponía 
que, durante dicho periodo de tiempo, la droga estaba fuera del mercado. Pero es indudable que ahora, después de la indagación realizada para este trabajo, ya nadie puede tapar el Sol con un dedo: pese a quien le pese, la talidomida continuó siendo utilizada en América del Sur, el mismo compuesto químico que provocó miles de bebés malformados en los cinco continentes.

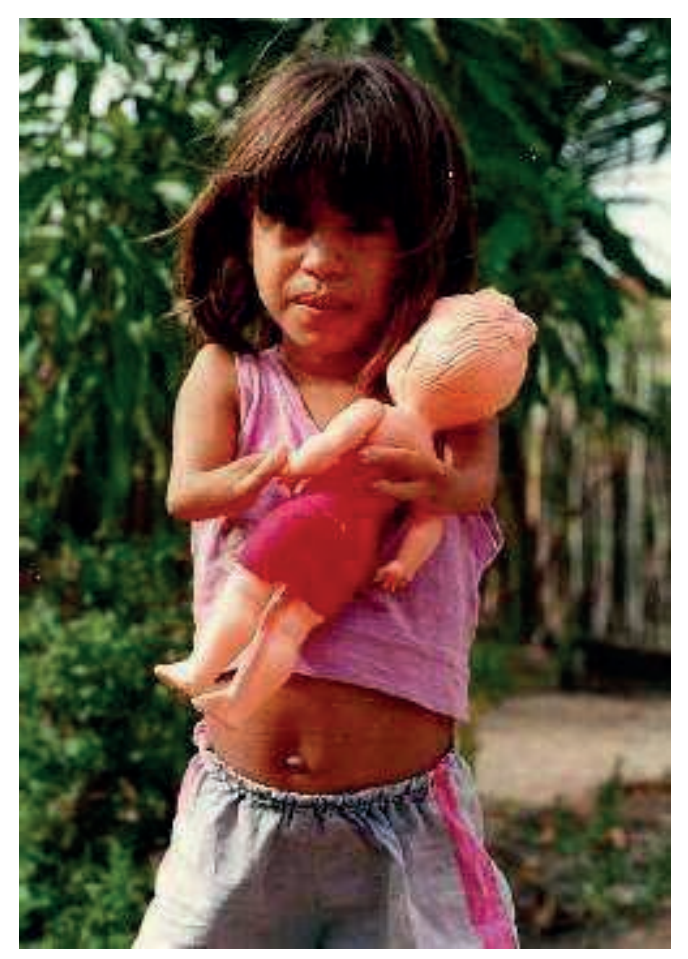

Imagen 27. Foto: James Cutler - Yorkshire TV. UK

Janelma no encuentra explicación por sus brazos inexistentes. La muñeca sí los tiene...

\subsection{Los débiles argumentos de la OMS}

Para Thalidomide.org una de las conclusiones más alarmantes del estudio realizado por ECLAMC en Sudamérica fue la forma como era prescrita la talidomida en mujeres con riesgo de embarazo. "Por lo general -señala el portal-, las mujeres que padecían la lepra en estas regiones habían sido medicadas con talidomida para periodos muy largos de tiempo, en algunos casos de 7 a 8 años, cuando el periodo 
normal para la MDT (siglas en inglés de Terapia Multi Drogas) contra la lepra ha sido recomendado a solo 12 meses. Esto implica que el tratamiento con talidomida para el ENL (Eritema Nodoso Lepromatoso) debe aplicarse por tiempo limitado, para reducir al mínimo el riesgo de embriopatía talidomídica en los fetos. Cuando se completa el tratamiento de MDT, entonces la paciente debe recuperarse de cualquier síntoma de ENL."

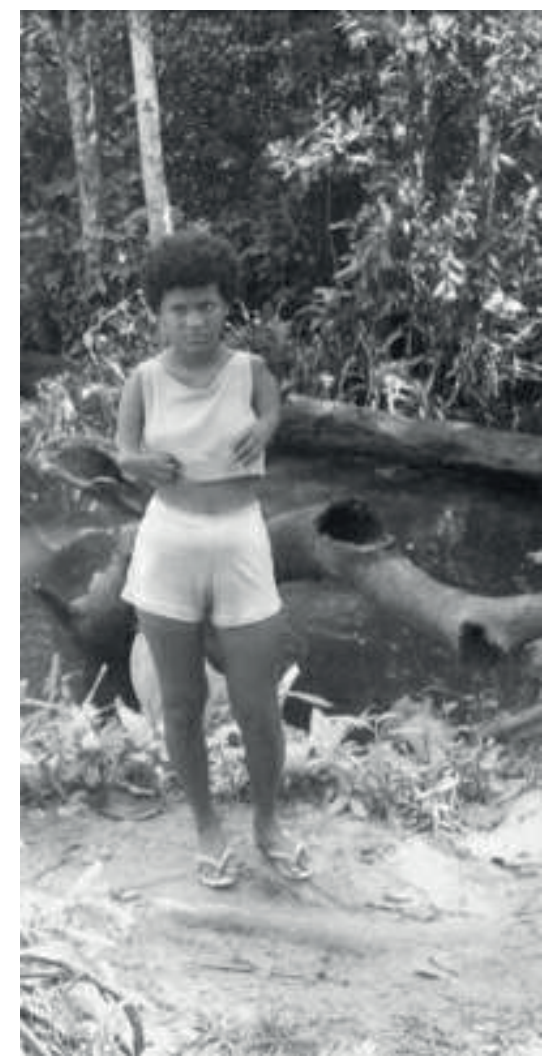

Imagen 28. Foto: James Cutler. Yorkshire TV. UK

Sandra es otra de las niñas víctimas de embriopatía de talidomida en la amazonía brasileña.

"Pero, -como explican los autores de la nota- al contrario de lo que se piensa, la talidomida se prescribe durante años; mostrando claramente que los argumentos de la OMS para introducir la droga en Sudamérica no pueden resistir una confrontación con la cruda realidad." El informe señala, entonces, que aquí, obviamente, los médicos están ansiosos de prescribir la talidomida a pesar que se trata de un 
teratógeno humano muy conocido por los daños que puede provocar en los bebés. "El asunto -señala Thalidomide.org - no es que el paciente sienta la necesidad de requerir una prescripción médica de la talidomida, sino que vistos sus efectos sobre sus males cutáneos desea más y más, como si se tratara de un narcótico: la talidomida actúa como un tranquilizante y el paciente se entrega a la droga."

Thalidomide.org insiste, pues, que desde 1965, cuando la OMS comenzó a trabajar con esta droga a posteriori del descubrimiento de Sheskin, la talidomida ha sido, y es, un teratógeno actual en América del Sur: una droga barata, de fácil adquisición en estas latitudes, muy al contrario de lo que sucede en los países desarrollados, donde adquirirla libremente es difícil y costoso, si no es recurriendo al mercado negro o a los clubes de compradores, haciendo engorrosos trámites ante las instancias oficiales para poder agenciarse de ella, prescrita siempre por un médico registrado y tras rigurosos exámenes y cautelas. En el Brasil, como ya se vio, la droga es fabricada localmente y puede llegar fácilmente a las poblaciones de bajos recursos con los auspicios de esta organización y la cooperación de los gobiernos y autoridades.

A la OMS, de tan encomiable labor en favor de la salud de cientos de millones de habitantes de países en desarrollo, se le inculpa, pues, de una serie de deficiencias u omisiones en sus políticas de estrategias y campañas para la aplicación de tratamientos con fármacos a gran escala, como ha ocurrido con la talidomida: a este organismo se le critica, por ejemplo, no haber sabido poner en práctica algún mecanismo de prevención contra las secuelas de este teratógeno, muy a pesar de su "lucha contra la lepra". También la han acusado de ser un intermediario o un agente de las multinacionales de la industria farmacéutica, como Chemie-Grünenthal o Bayer -recuérdese que por algo se habla de los "Bayer's clubs"-, que la estarían utilizando para probar sus productos quìmicos en el tercer mundo, con el pretexto de que realizan una labor humanitaria, introduciendo fármacos y drogas en la población más pobre para que ésta haga de "conejillos de indias". 
Otros autores responsabilizan de este reciente aumento de casos de malformaciones congénitas en los bebés -descubierto durante las investigaciones realizadas tanto por Thalidomide.org como por el ECLAMC- a los médicos, que, como afirman, no han sabido advertir bien a los pacientes sobre los peligros que su uso inadecuado representa; no falta quienes señalan a las/los mismísimos pacientes, a quienes acusan de no saber o no querer utilizar responsablemente la medicina, siguiendo las indicaciones médicas al pie de la letra, atribuyendo sus secuelas -embriopatía talidomídica- a este comportamiento, producto más que nada de la ignorancia y los prejuicios, que de un conocimiento previo para la aplicación de la droga pacientes con lepra. "Es que aquí no funciona aquello de "Ud. no puede quedar embarazada mientras tome la talidomida"", comentó un médico consultado por este autor, pues por lo visto, suele suceder, por ejemplo, que el esposo, o el conviviente, o la pareja de turno de la mujer, no entiende el porqué ella no puede quedar embarazada durante el tratamiento e insiste en tener relaciones sexuales, sin considerar su situación, sin cuidar a la pareja de lo que pueda sucederle por sentirse obligada a tolerar una unión carnal contra su voluntad.

\section{5. ¿Provocando un nuevo desastre?}

La forma como se está aplicando la talidomida en regiones como la amazonía peruana y brasileña parece estar incitando un nuevo desastre. A esto se agrega el sintomático hecho de que la ocurrencia continuada de casos de embriopatía talidomídica se limite al mundo subdesarrollado -como ya se mencionó arriba-, donde la lepra es más común y hay muy pocas medidas de control para la droga. Sin embargo, se insiste en probar nuevas aplicaciones para ella en los ensayos clínicos llámese cobayas humanos-, y ECLAMC teme que esto se preste para la ocurrencia de un nuevo desastre farmacológico, tan grande como el de los años $60 \ldots$ tragedia que en realidad ya está ocurriendo otra vez. 
Como la talidomida es un medicamento de bajo costo de producción, crece el potencial de la droga de extenderse en el tratamiento de muchas enfermedades comunes. En esto conspira también la alta proporción de embarazos imprevistos en muchos países -donde incluso existe la idea machista de que a más hijos más virilidad, sin importar si se tienen o no los medios y recursos suficientes como para criar a tantos hijos - y la dificultad que tienen las autoridades en regular y controlar el uso y tráfico de medicamentos como la talidomida en Sudamérica.

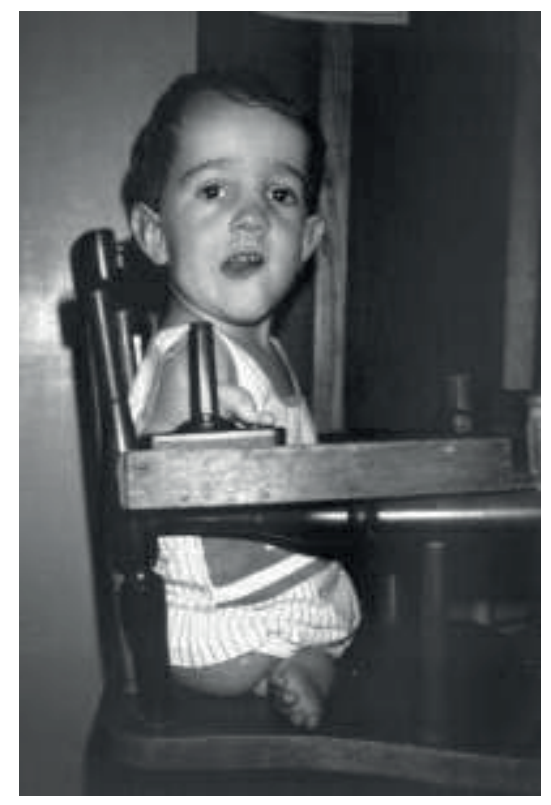

Imagen 29. Foto: James Cutler. Yorkshire TV. UK

Gerson es el nombre de este niño. Su inocencia no tiene brazos.

Pero esta amenaza de un segundo desastre farmacológico también se cierne sobre el mundo desarrollado. ECLAMC señaló hace poco que cada vez hay más demanda de talidomida por varios países desarrollados, "por tal motivo -prosigue el articulo-, si surge una nueva epidemia de aquellas enfermedades que han aparecido en estos últimos tiempos, como el SIDA, entonces va a aumentar esta demanda, en la que compradores de países desarrollados, haciendo caso omiso a los controles y sistemas 
de supervisión y prevención de las malformaciones teratógenas, adquieran la talidomida de laboratorios brasileños o argentinos." Los investigadores de ECLAMC temen, pues, que un uso descontrolado de la talidomida en países como Estados Unidos o Alemania, introducida allí bajo no sabemos qué subterfugios, adquirida en un mercado negro que crece en forma proporcional a la demanda clandestina, aumente la frecuencia de anomalías congénitas atribuibles a la talidomida.

A pesar del progreso hecho en la vigilancia de los defectos de nacimiento durante los últimos 30 años, el mundo está todavía en la misma situación de los años sesenta, cuando estalló el escándalo de la talidomida y las malformaciones congénitas se extendieron por todo el mundo... que no se librará del peligro mientras la talidomida siga siendo un teratógeno actual en Sudamérica.

\section{La droga omnipresente}

\subsection{Las muchas caras de la talidomida}

\section{Compilado por Randolph Warren / CEO}

7 de mayo de 1999

Este documento pretende enumerar de la mejor manera posible todos los nombres de marca de la talidomida que se vendieron en el mundo entero entre 1957 y 1963, proporcionando también un listado de todos los países donde la droga estuvo disponible. La lista incluye también las fechas aproximadas de la disponibilidad de talidomida en los mercados de cada país.

En algunos casos, los nombres de marca aparecen en blanco, aunque se sabe que la droga estaba allí, ya sea porque fue adquirida por las víctimas de manera informal, o porque ésta llegó a ellos en su propio país y/o porque las madres la consiguieron como muestras médicas o de alguna otra fuente. Ciertos países no tienen ninguna 
"fecha" referencial disponible, debido a que la droga no fue aprobada en dicho lugar, por lo que se ignora si allí había disponibilidad de este medicamento. En todo caso, la droga no habría podido estar en circulación antes del 1 de octubre de 1957, fecha del primer lanzamiento comercial de la talidomida en Alemania Occidental (llámese Contergan).

Es virtualmente imposible enumerar totalmente los nombres de marca y cada posibilidad en que la talidomida estuvo disponible en determinado país, cuando no hay prueba de ello.

\section{Los motivos del FDA}

\subsection{La primera de una segunda vez}

La tragedia de la talidomida cambió el modo en que las fórmulas químicas se desarrollan, prueban y regulan, ampliando considerablemente el prestigio de una institución como la FDA que, gracias a la intervención de la doctora Frances Kelsey, confirmó su reputación como autoridad líder en lo referente al mundo de la seguridad en alimentos y medicamentos. En 1998, entonces, la Food \& Drug Administration de los Estados Unidos aprobó la comercialización de la talidomida para el tratamiento del eritema nudoso (ENL), una complicación de la lepra, un trastorno de deformación de la piel que conlleva una pérdida del tacto que puede conducir a la parálisis. Aunque algunos, con razón, no le perdonan su pasado, esta aprobación ha sido considerada como un avance médico para luchar contra numerosas enfermedades, como ocurre con ciertos tipos de cáncer.

Según una reciente encuesta, se sabe que las dos terceras partes de las mujeres en edad fértil no tienen idea de lo que es o era la talidomida. Curada del susto, la FDA ha puesto una serie de exigencias para la prescripción clínica y consumo de esta 
droga, toda vez que los médicos pueden recetarla a mucha gente contra otras enfermedades, pero respetando siempre sus contraindicaciones.

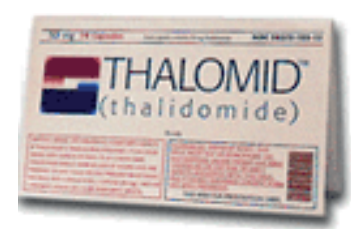

Thalomid (

Imagen 30. Ilustración Geosalud.com. El nuevo Thalomid.

Su efectividad en el tratamiento del ENL la ha convertido en la esperanza para el tratamiento de muchas otras enfermedades. Se ha demostrado, por ejemplo, que la talidomida tiene una notable acción sobre las úlceras graves de la boca y la garganta en individuos con SIDA, y las úlceras en la boca y los genitales de las personas con la enfermedad de Behchet. Se trata de llagas ulcerosas grandes, profundas y dolorosas. Las heridas de la boca pueden conducir a debilitamiento y la deficiencia nutricional puesto que hacen muy difícil la ingestión de alimentos.

La talidomida también ha sido estudiada como medicamento para otras enfermedades inflamatorias como el lupus eritematoso, el rechazo tardío de un injerto en un receptor, el síndrome de Sjodren, la artritis reumatoide y la inflamación de los intestinos. Asimismo se están realizando pruebas para confirmar la posible relación de la talidomida con una enfermedad ocular que puede producir ceguera, llamada degeneración macular, a ciertos cánceres y a la gran pérdida de peso que experimentan los enfermos de SIDA y de cáncer, aunque todavía falta para que se pueda demostrar su efectividad contra estas enfermedades.

La nueva talidomida, que ha sido lanzada al mercado con el nombre comercial de Thalomid (38 - 39a - 39b) por los laboratorios Celgene (40), de no ser utilizada convenientemente, esta droga puede provocar una serie de secuelas adversas, tales como daños nerviosos graves (neuropatía periférica) (41), que pueden resultar ser 
irreversibles después de que el paciente deje de tomar talidomida. Los síntomas incluyen una sensación de quemazón, adormecimiento u hormigueo en los brazos, las manos, las piernas o los pies.

12.2. S.T.E.P.S., los bebés primero

Debido al grave riesgo que el uso de la talidomida representa para madres gestantes y bebés, la Food \& Drug Administration ha permitido su comercialización con una serie de especiales medidas de seguridad nunca antes impuestas con ninguna otra droga. Para impedir la exposición fetal a la talidomida, el fabricante de la droga ha desarrollado un programa denominado Sistema para la educación sobre la talidomida y la seguridad en su receta o S.T.E.P.S. (System for Thalidomide Education and Prescribing Safety) (42). Mediante esto, la talidomida sólo puede ser recetada por médicos matriculados (o colegiados), y sus pacientes, tanto varones como mujeres, deben someterse a medidas anticonceptivas obligatorias y a la matriculación y encuesta de pacientes.

En Estados Unidos la talidomida sólo puede ser distribuida por farmacéuticos autorizados que se hayan inscrito en el S.T.E.P.S. que estén capacitados para comprender el riesgo que pueden correr los pacientes que acuden a sus establecimientos, especialmente mujeres embarazadas. La FDA recomienda, además, no administrar la droga, aunque ésta haya sido debidamente recetada, a ninguna mujer cuando la prescripción no vaya acompañada de un informe escrito del médico, certificando haberse realizado una prueba de embarazo en las últimas 24 horas, como requisito para iniciar una terapia con talidomida y que dicha prueba haya resultado negativa. Se exigirá además la realización de pruebas de embarazo una vez por semana durante el primer mes de uso, luego una vez por mes en el caso de mujeres con ciclos menstruales regulares o, en el caso de mujeres irregulares, cada 15 días. Las recetas sólo podrán ser extendidas a la paciente durante un mes. 


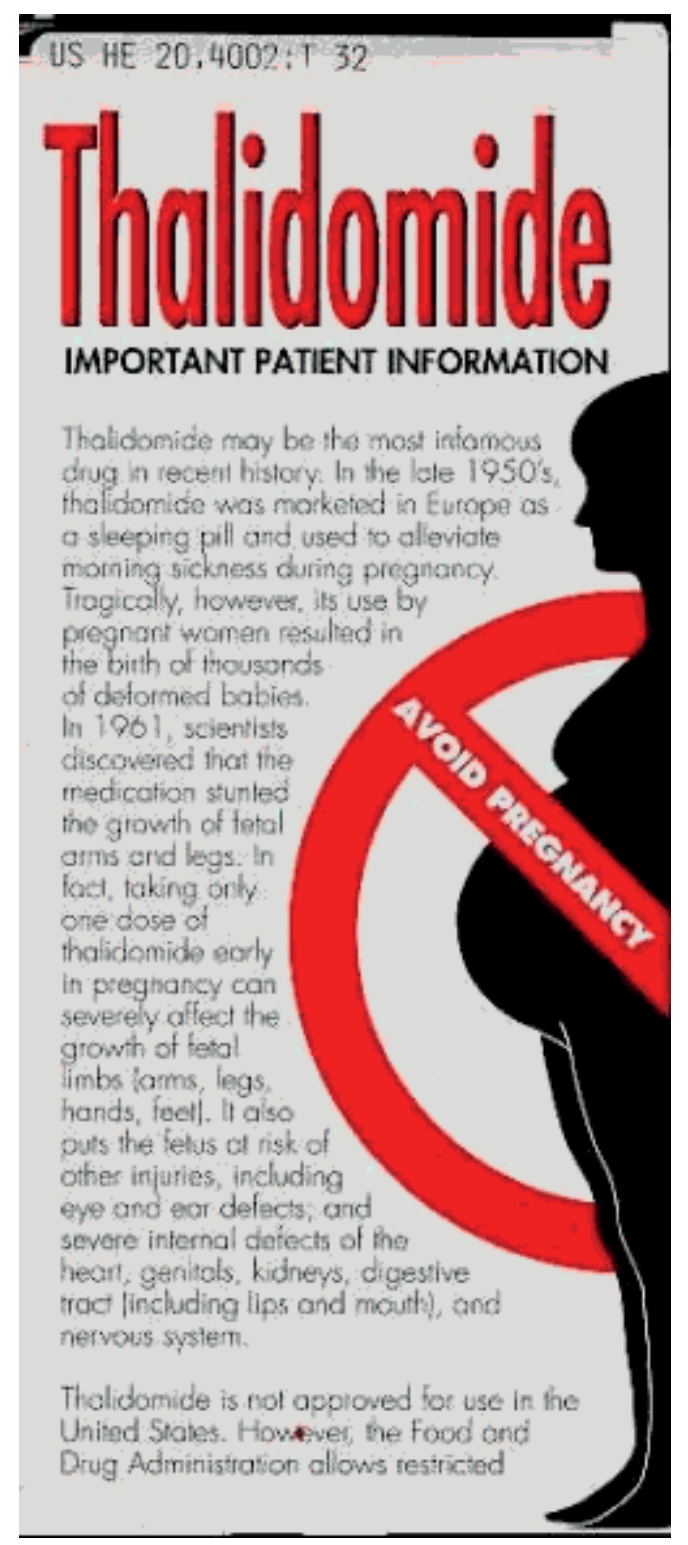

Imagen 31. Ilustración: FDA

En EEUU la Food \& Drug Administration divulgó este cartel educativo para prevenir un mal uso de la talidomida.

Durante el tratamiento, una paciente femenina no deberá tener relaciones o utilizar dos métodos altamente eficaces de control de la natalidad al mismo tiempo durante por lo menos un mes antes de comenzar a utilizar talidomida. Todos los pacientes deberán inscribirse en un registro obligatorio que servirá para realizar el seguimiento 
y la detección de efectos adversos del uso de la talidomida que podrá, quizás, identificar áreas en las que es necesario mejorar las medidas de seguridad si se presentan problemas.

Por otro lado, la FDA recuerda a las pacientes femeninas que no hay método anticonceptivo que sea fiable al 100\%, y que la medida más sana y segura es la de no tener relaciones sexuales con la pareja, por lo que las mujeres tratadas con talidomida no deben tener nada que pueda provocar un embarazo, ni mucho menos una fertilización asistida. Igualmente está prohibido amamantar a un bebé y donar sangre. Es vital también que cada paciente comprenda que la talidomida sólo ha sido prescrita para él o ella y que no debe ser compartida ni dada a otros. Se advierte también a las pacientes que, a menudo, la talidomida causa somnolencia. Debe evitarse el tomar alcohol y otros medicamentos que puedan causar somnolencia, lo que puede causar problemas a la hora de conducir un vehículo o de operar máquinas. También puede reducir la capacidad de alerta y de pensar con claridad.

\subsection{Promesa... y alerta para el futuro}

Uno de las objetivos del programa S.T.E.P.S. del fabricante Celgene es estudiar y desarrollar la eficacia de análogos de la talidomida, vale decir, compuestos químicos que pueden tener los beneficios de la talidomida sin sus efectos tóxicos y teratógenos. Algunos de estos compuestos ya están a punto de pasar a la fase de ensayos y pruebas clínicas.

También se ha investigado sobre el modo en que la talidomida causa una gran variedad de defectos de nacimiento en estrecha relación con el momento del embarazo en que la mujer la toma. El aprendizaje de cómo actúa sobre el embrión recomendamos leer también "La Talidomida: Importante información para el paciente" (43) - deberá proporcionar mayores conocimientos sobre los procesos 
principales del desarrollo normal del feto y sobre el modo en que las drogas u otros químicos pueden interferir negativamente en este desarrollo.

Adaptado de un artículo publicado por "March of Dimes Birth Defects Foundation", año 2002 (44).

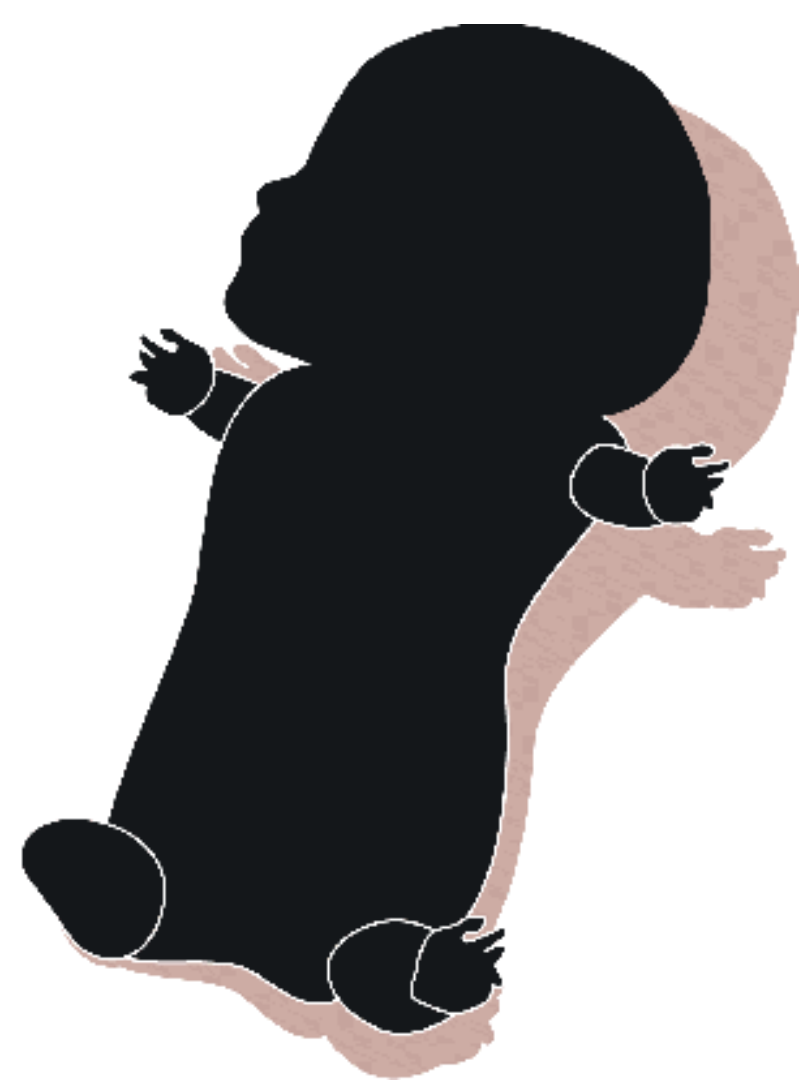

Imagen 32. Ilustración: FDA

Silueta de bebé con focomelia. Del mismo cartel de la FDA.

\section{2. ¿Qué es la focomelia talidomídica?}

Es conocido que ciertos medicamentos tienen efectos teratógenos sobre los organismos vivos y por ello los médicos deben tener especial cuidado en prescribirlos. La talidomida es precisamente uno de los más peligrosos. El término teratógeno (del griego teratos $=$ monstruo y geno $=$ nacer) se aplica al efecto 
malformante que estos fármacos tienen sobre el feto, cuando son ingeridos durante el embarazo. (Nota 12)

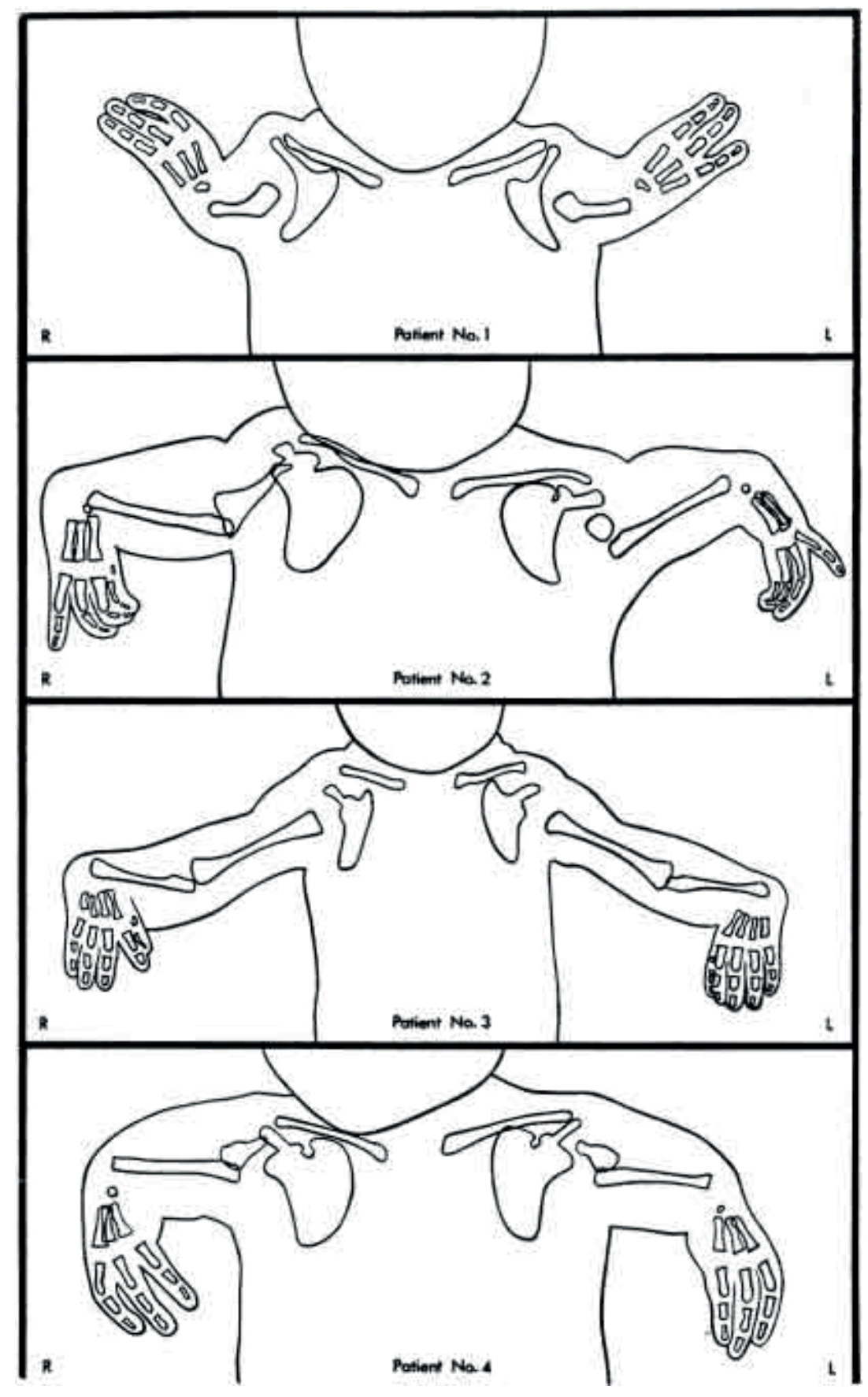

"Los medicamentos pueden dañar al feto en cualquier momento del embarazo señala una monografía publicada por el Boletín Terapéutico Andaluz en 1995 (44b) - 
, aunque el período de mayor riesgo es el primer trimestre, ya que durante la fase embrionaria (desde el día 20 hasta el 55) tiene lugar la formación de la mayoría de los órganos, por lo que existe más posibilidad de que un medicamento induzca anomalías estructurales sobre el feto, que son las malformaciones morfológicas más importantes. Durante la etapa fetal, desde la $8^{\text {a }}$ semana hasta el parto, los fármacos pueden afectar el crecimiento y desarrollo funcional del feto, originar anomalías morfológicas de menor gravedad, e inducir complicaciones en el parto. Hay que tener en cuenta que los distintos órganos o sistemas en formación poseen distinta sensibilidad a sufrir teratogénesis." 


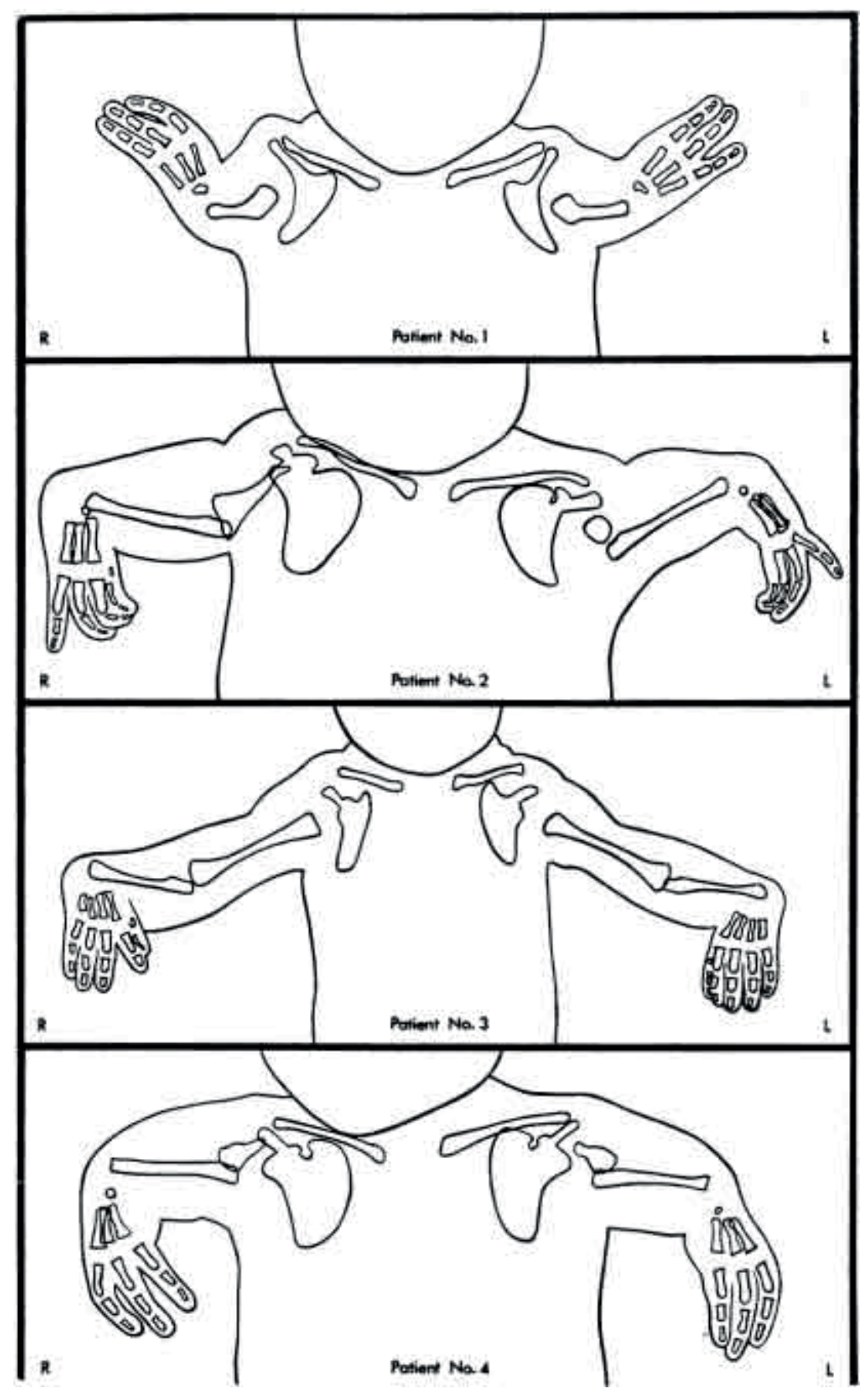

Imagen 33. Ilustración: Journal of the Association of Children's Prosthetic-Orthotic Clinics (JACPOC)

Radiografía de cuatro casos de focomelia talidomídica.

Los miembros que van a formar extremidades en una persona constituyen campos morfogenéticos independientes, esto es, grupos de células cuyo desarrollo son 
independientes del individuo. Hay células cuya capacidad de diferenciación es independiente de la del resto. Las malformaciones suelen ser más frecuentes en las extremidades que en otras partes del organismo porque en los miembros no son letales. Si la malformación ocurre en un órgano vital, el embrión morirá. Para clasificar dichas anomalías de las extremidades, se utiliza el término melia (miembro).

Un fármaco teratógeno puede provocar distintos tipos de malformaciones congénitas en los miembros del feto (44c), los cuales reciben sus propias denominaciones: así, cuando falta un miembro, se denomina amelia; cuando falta un segmento de un miembro, recibe el nombre de meromelia; cuando hay un miembro más pequeño de lo normal, recibe la denominación de micromelia; también son anómalos los miembros ubicados en lugares extranormales o miembros supernumerarios, y la bimelia cuando el miembro está en un lugar anormal.

Por su parte, los dedos de las extremidades también pueden padecer diversas malformaciones congénitas. Para ellos se utiliza el término dactilia (dedos), los mismos que en circunstancias normales se forman por una degeneración del tejido interdigital. Un fracaso en dicha degeneración va variar el número de dedos. Se denomina entonces sindactila cuando hay menos dedos de lo normal -tres o cuatro en cada pie o mano en el caso de las víctimas de la talidomida -; polidactila cuando hay más dedos de lo normal -a veces hasta siete en el caso de los talidomídicos-. En cuanto a las malformaciones en las articulaciones, éstas suelen ser poco frecuentes en los seres humanos, siendo más conocida la llamada displasia, -una degeneración de las superficies articulares de la cadera (cabeza de fémur y acetábalo) -, que afecta también a los animales, sobre todo perros de razas pequeñas, y suele producirse por causas hereditarias. 

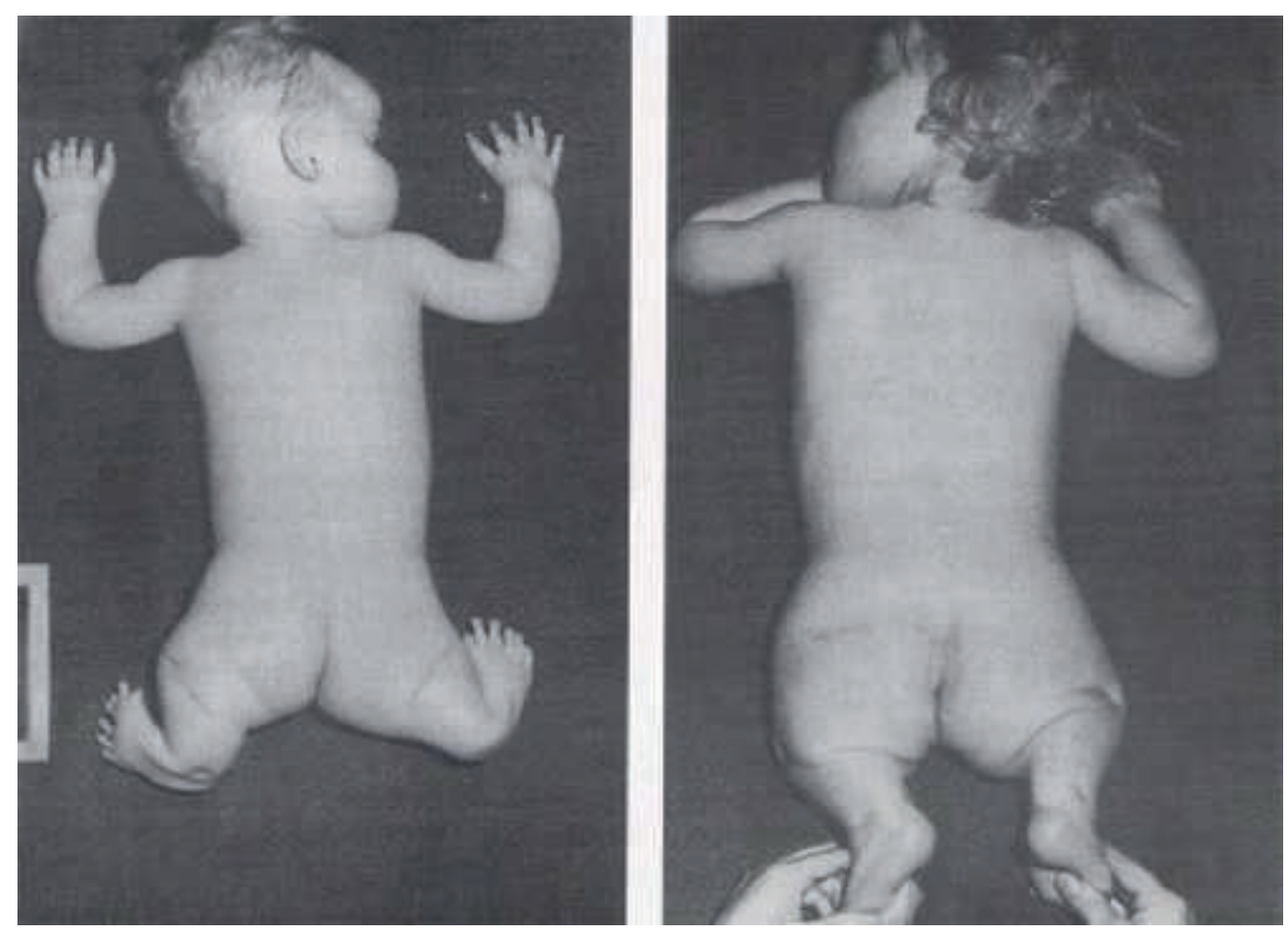

Imagen 34. Foto cortesía José Riquelme.

Dos pequeños bebés alemanes en los que se aprecian las brutales secuelas de la talidomida. Alemania fue el país donde el Contergan dejó la mayor cantidad de víctimas.

Pero la llamada focomelia o miembro de foca, un defecto congénito muy raro antes del desastre de la talidomida, es tal vez la más conocida de las malformaciones provocadas por un fármaco teratógeno. Se trata de una anomalía en la que al miembro le falta el segmento más proximal -generalmente el que la une al resto del cuerpo-. Se produce cuando la paciente embarazada ingiere talidomida en las primeras etapas del embarazo. Una vez en contacto con la placenta, la droga inhibe el desarrollo de los vasos sanguíneos y la formación de las extremidades del embrión, ya sean superiores o inferiores, incluso ambas, pues es precisamente en esta época de la gestación cuando se configuran los brazos y las piernas del futuro bebé. La consecuencia de esta acción es lo que la medicina llama focomelia, es decir, el 
crecimiento anómalo denominado miembros de foca debido a la forma que adquieren los remanentes de las extremidades malformadas.

En 1960, con la talidomida convertida en una verdadera "droga de estilo de vida", nadie sospechó lo que se venía; toda vez que los médicos tenían la confianza de que una malformación congénita de este tipo no solía tener características epidémicas; sin embargo, con la talidomida no fue así... y cuando comenzaron a multiplicarse los casos de malformaciones congénitas, como nunca se había visto antes, los especialistas de todo el mundo tuvieron razones para estar preocupados.

El médico alemán Widukin Lenz fue el primer científico en dar la voz de alerta en 1961, cuando, durante una conferencia, habló de un medicamento muy popular que era consumido por miles de mujeres embarazadas, y estableció una relación entre esta droga y los niños malformados que estaban naciendo por todas partes. Al enterarse la opinión pública y la prensa alemanas de que tal medicamento era nada menos que el Contergan, el fabricante del mismo, Chemie-Grünenthal, se vio envuelto en el mayor escándalo farmacológico de la historia. Ésta resultó ser una sorpresa muy desagradable hasta para los mismísimos fabricantes de la droga, toda vez que la talidomida no había demostrado ser un agente teratógeno en las pruebas realizadas en roedores, lo que había llevado erróneamente a la industria farmacéutica a creer en el mito de la inocuidad.

Nota 12: Vea más información sobre medicamentos teratógenos en: ¿Qué es un fármaco teratógeno?

http://www.cfnavarra.es/bif/txt/15/30terato.html

Medicamentos peligrosos para el feto

http://wzar.unizar.es/cfva/bol/bol6.html 


\section{3. ¿La talidomida afecta el código genético?}

Uno de los temores más inquietantes sobre el uso de la talidomida es la posibilidad de que las malformaciones congénitas provocadas por este fármaco sean transmitidas por las víctimas a otras generaciones. A esto aludía el patólogo Peter Huang (44a) cuando en 1999 aseguró que el fármaco podía afectar el código genético del embrión, lo que implicaría que las malformaciones producidas por la Talidomida alterarían el ADN y se transmitirían de generación en generación.

Una de las primeras víctimas alemanas de la talidomida, que nació sin brazos ni piernas, fue portada de "El Diario del siglo XX", correspondiente al año 1962, un suplemento especial publicado por el matutino madrileño El Mundo.

Huang basaba su afirmación en un estudio realizado conjuntamente con su colega Willian McBride (científico australiano quien, al igual que el doctor Widukin Lenz, fue uno de los primeros en sospechar sobre las secuelas de esta droga en los fetos), el mismo que advertía la posibilidad de daños irreversibles en el ADN (código genético) de óvulos y espermatozoides. Por consiguiente, las malformaciones congénitas provocadas por la talidomida podrían ser transmitidas de padres a hijos, hereditariamente, afectando a varias generaciones.

José Riquelme cuenta en "Hijos de la talidomida" que McBride obtuvo parte de sus conclusiones de un seguimiento realizado a dos familias británicas de víctimas de la talidomida, en las que tanto padres como hijos habían nacido malformados. Sin embargo, esta afirmación no ha sido científicamente demostrada hasta la fecha; en esto el tiempo será el único que podrá confirmar tal presunción, cuando nazcan hijos de la tercera o cuarta generación de la descendencia de las víctimas de esta sustancia teratógena. 
Si se demuestra que, además de provocar malformaciones congénitas en los bebés, la talidomida las transmite a otras generaciones, ésta sería la primera vez que un fármaco rompe la barrera generacional y sus efectos se hacen hereditarios. Esta posibilidad ha hecho que en Londres, un grupo que lucha por los derechos de las víctimas de esta sustancia, presentara un documento en la sede del laboratorio Guiness -uno de los fabricantes de la Talidomida en Gran Bretaña, país donde esta droga causó unas 350 víctimas - para solicitar a la empresa invertir más dinero en investigaciones sobre sus consecuencias.

Ya ha quedado demostrado que la talidomida no daña las facultades mentales; de otro modo esta pequeña víctima alemana del Contergan no podría realizar sus operaciones complejas en una pizarra.

La polémica aprobación por la FDA americana para la fabricación y comercialización de la talidomida, ciertamente ha causado suspicacias y nuevos temores de las víctimas de la droga, que han visto reaparecer los viejos fantasmas y horrores de las malformaciones congénitas sufridas por ellos. Y a pesar de lo que se afirma acerca de los nuevos usos de esta sustancia, los "thalidomides" como les dicen a las víctimas, vienen reclamando un cambio de actitud respecto a ella o la eliminación de la droga. "Hoy la talidomida puede aliviar el sufrimiento y mejorar la calidad de vida de otros enfermos -escribe Gonzalo Casino en el portal Doyma (61) - . No se puede ignorar pero tampoco prohibir, porque fomentaría el mercado negro. Por eso su reintroducción en el mercado se ha hecho en Estados Unidos con no pocas cautelas para asegurarse que ninguno de los pacientes, hombres o mujeres, que reciban tratamiento engendrará hijos desde un mes antes de iniciar el tratamiento hasta un mes después de concluirlo. Pero los afectados piden algo más. "Pedimos que se investiguen análogos que sustituyan a la talidomida, con todos sus beneficios pero sin sus efectos teratogénicos", afirma Warren (Ver Ref. 61). "Y para cuando se 
desarrolle el nuevo análogo, pedimos la eliminación de la talidomida de este planeta".

\section{Talidomida clandestina}

\subsection{Los entretelones de un mercado siniestro}

En noviembre de 1999, un artículo publicado por el portal español Doyma, decía que no se podía prohibir la talidomida porque de otra manera se fomentaría el mercado negro. Al margen de esta afirmación, lo cierto es que tampoco parece ser necesario que se apruebe la comercialización de esta droga para que no exista dicho mercado porque, de hecho, "debajo de la mesa" ya hay un mercado que se mueve clandestino desde hace muchos años, generando multimillonarias ganancias para los fabricantes de la droga.

En otra de sus reveladoras entregas, los autores de Thalidomide.org parecen coincidir con Doyma y se hacen eco de la infinidad de voces que hablan de la existencia de este tráfico a vista y paciencia de gobiernos y autoridades sanitarias de todo el mundo.

\subsection{El uso de la Talidomida crece oculta e ilegalmente}

"La Talidomida se extiende eludiendo el control de las autoridades. Los grupos "SIDA" tienen sus propios recursos en Internet para acceder a la droga", dice Thalidomide.org, cuando denuncia que estos grupos son prácticamente quienes tienen la sartén por el mango.

Los enfermos de SIDA y cáncer en todo el mundo, con la ayuda de Internet, se han convertido en los blancos hacia dónde va dirigido este mercado, toda vez que muchos de ellos han formado sus propias asociaciones para poder agenciarse la 
talidomida mediante un tráfico procedente de Centroamérica y Sudamérica, existente ya desde antes de 1998. Un "mercado negro" del que ya tenían conocimiento las autoridades estadounidenses, tal como se desprende de lo señalado por Thalidomide.org: "Una búsqueda en la web da cientos de direcciones para el término "talidomida". Muchos de los enlaces conducen a páginas mantenidas por y dirigidas hacia grupos de gente que padecen SIDA o cáncer. La Agencia para el Control de Alimentos y Drogas de Estados Unidos de Norteamérica (FDA) intentó limitar el acceso a esta droga a mediados de la década de los 90. Sin embargo, el tráfico de la talidomida desde Brasil y México hizo prácticamente inútiles los esfuerzos de la FDA por controlar su uso." Brasil consume sólo $400 \mathrm{Kg}=881,848$ libras = 62,989 "stones" (medida de peso equivalente a 14 libras) de los $1200 \mathrm{~kg}=2645,544$ libras $=188,967$ "stones" de talidomida producida en el país cada año. Dos tercios de la droga se exportan legalmente o de contrabando, o bien se venden en el Mercado Negro Brasileño.

Para hacer frente a este mercado que a mediados de los 90 ya alcanzaba proporciones escandalosas, traficando con una droga que supuestamente estaba fuera de circulación, las autoridades norteamericanas tomaron cartas en el asunto, aunque sin mucho éxito fuera de los Estados Unidos: "La FDA decidió poner en marcha su nuevo programa de emergencia de investigación de la droga (IND) que proporciona acceso a la talidomida para el tratamiento de úlceras y debilidad con pérdida de sensibilidad -prosigue el portal-. Para que un paciente sea autorizado por el plan de emergencia (IND), un médico debe remitir a la FDA un informe que contemple: 1) localización de las úlceras; 2) duración de las úlceras; 3) todas las terapias previas ensayadas; 4) cultivo reciente de herpes de resultado negativo; 5) informe de biopsia; 6) historial negativo de neuropatías periféricas; 7) pérdida de peso, documentada".

"Las tomas de decisión de la IND tardan de 24 a 48 horas -prosigue el artículo - . Una vez que el IND aprueba el uso de la talidomida, la FDA suministra gratis la droga 
durante un mes. Los médicos solicitan la droga directamente de los fabricantes, Celgene Corporation o Andrulis. Pediatric Pharmaceuticals es la tercera compañía autorizada para comercializar la talidomida en USA. Pediatric Pharmaceuticals proporciona la droga al precio de 1 \$ cada píldora de $100 \mathrm{mg}$. (Celgene cobra 6,56 \$ por píldora de $100 \mathrm{mg}$ )". De esta manera se intentó desarticular el mercado negro, pero...

\subsection{Vía de acceso a los "Clubes de Compradores"}

Según plantea Thalidomide.org, una forma menos oficial de obtener la droga es por medio de los llamados "Clubes de Compradores". Los Clubes de compradores proporcionan medicamentos experimentales para la gente afectada de SIDA y hacen posible el acceso a la talidomida procedente de fuentes ocultas e ilegales. Hasta hace unos pocos años, tres de esos clubes de compradores anunciaban la talidomida en sus páginas web: El PWA Healthgroup en Nueva York, Healing Alternatives en San Francisco, y Life Link en las cercanías de Santa Bárbara. Cuando se escribió esta nota, Healing Alternatives todavía suministraba talidomida a través de su página web.

El precio de la talidomida también oscila mucho de unos clubes de compradores a otros. El precio en el PWA Healthgroup es de 2,25 \$ por píldora de $100 \mathrm{mg}$ o de 22,50 \$ por caja de 10 píldoras - un tratamiento para diez días. Life Link vende la droga en cápsulas de $50 \mathrm{mg}$ a 60 \$ la caja.

\section{4. ¿Ausencia de efectos secundarios?}

"Los efectos secundarios, naturalmente, no se encuentran resaltados en las cabeceras de los prospectos de las páginas web relacionadas con el SIDA -dicen los autores del artículo-. Sin embargo, mencionan que se pueden producir algunas reacciones alérgicas por el uso de la talidomida, especialmente a dosis altas (300 ó 400 mg 
diarios - lo que representa más de dos veces la dosis diaria cuando se usa como calmante). En una encuesta llevada a cabo en Tailandia, seis pacientes tratados con talidomida desarrollaron erupciones cutáneas como resultado del uso de la droga. Otras reacciones hacían referencia a fiebre alta y síntomas de gripe grave". Lo que es lo mismo que decir, además del negociado ilegal, que hay una manipulación acerca de la información dirigida a los pacientes sobre las características del producto farmacéutico y las secuelas desagradables que estos podrían causar sobre el organismo.

Las acciones de diversos clubes de compradores forzaron a la FDA a tomar actitudes más liberales frente al uso de la talidomida. La FDA se dio cuenta de que el uso de la talidomida jamás podría erradicarse. En la ilustración, el logotipo de Healing Alternatives, uno de los clubes de compradores más conocidos. (68 - 69).

Sobre este punto, Thalidomide.org advierte que los científicos estadounidenses, conocedores también de este tráfico de medicamentos, "han encontrado que, a largo plazo, el uso de esta droga (talidomida) puede causar neuropatías periféricas. Pero no es preocupante la situación, según estas mismas fuentes. Las neuropatías periféricas pueden evitarse fácilmente comenzando el tratamiento a dosis bajas: 100 mg diarios, (de 50 a $100 \mathrm{mg}$ diarios era la dosis recomendada en los años 60); o alternando el uso de la droga si fuera necesario. Y como una nota extremamente relevante, se hace hincapié en que el Dr. Gilla Kaplan, de la Universidad Rockefeller, en las páginas Web de los grupos de ayuda a gente con SIDA y cáncer, estima que las personas infectadas con el HIV y que están siendo tratadas con TB no parecen experimentar reacciones alérgicas." 


\section{6. ¿Sabía usted qué...}

...el 79\% de las mujeres embarazadas suele tomar fármacos de efecto desconocido, por lo que están expuestas a medicamentos cuyos riesgos superan a los beneficios o para los que no se dispone de datos relativos a su uso durante el embarazo, según una investigación publicada en la revista The Lancet? (EL PAÍS, Barcelona 21/11/00 (49)).

...la talidomida (...) podría convertirse en una bendición para algunos enfermos de cáncer, según una investigación realizada por científicos de la Clínica Mayo en Estados Unidos (...), que han comprobado que puede detener, o al menos frenar, el avance de un cáncer llamado mieloma que se caracteriza por el crecimiento excesivo y el mal funcionamiento de células plasmáticas en la médula espinal, según una información publicada por la agencia EFE? (50).

..." En los últimos años, los estudios han sugerido que la talidomida podría ser útil para tratar enfermedades como la lepra, la tuberculosis, algunos cánceres, y la pérdida de peso en pacientes con sida? Hoy, unos 1.000 pacientes en EEUU están tomando esta medicación". (Buenas Noticias, junio 1998 (46)).

...en Gran Bretaña, se ha estimado que la talidomida provocó unas 325 víctimas entre 1957 y 1961 (...)? (Boletín AIS Perú, 1999 (47)).

..."Según una encuesta reciente, las dos terceras partes de la gente en edad de procrear no conoce bien la talidomida..."? (Reseña de Delpaciente.com (48)).

...la FDA se ha convertido en una de las organizaciones públicas más prestigiadas de los Estados Unidos, como se desprende de una encuesta realizada en 1999 por el Pew Research Center y el Princeton Survey Research Associates, donde la FDA recibió 
una clasificación completa y favorable de más del 80 por ciento, más del doble de la aprobación de todo el gobierno? (Reseña de U.S. Food and Drug Administration February 2002 (51)).

..."la ingestión de una sola dosis de talidomida durante el comienzo del embarazo puede provocar graves defectos de nacimiento? Ahora se sabe que las mujeres que no pueden evitar la probabilidad de quedar embarazadas no deben tomar talidomida." (Reseña de March of Dimes (Ver Ref. 52)).

..."Actualmente, la talidomida está comercialmente disponible en la Argentina, a través de un mecanismo engorroso y burocrático, por el cual el paciente debe firmar un consentimiento en que se hace cargo de estar recibiendo una droga que ha provocado graves malformaciones. Lamentablemente, las autoridades sanitarias argentinas se han limitado a establecer regulaciones para la talidomida solamente: no han implementado programas similares (ni de ningún otro tipo) para otras drogas marcadamente teratogénicas..." Tomado de "Drogas en embarazo? (Documentos Médicos: categorización según la FDA" (57)).

..."En América Latina, y en la Argentina en particular, la Talidomida es utilizada en el tratamiento de la lepra (eritema nodoso de la lepra o reacción leprosa tipo 2) y el Sida? (OEI.org (62)).

\section{La píldora del ayer ha forjado héroes (y heroinas) del hoy}

\subsection{Un libro contra la talidomida}

José Riquelme López es un murciano como pocos, de pura cepa como se dice. Él es una de las tantas víctimas que la talidomida dejó en España, aunque, a decir verdad, tuvo mucha suerte. Su madre tomó uno de los fármacos con esta letal sustancia, cuando José aún comenzaba a patalear en su barriguita, sin imaginarse lo que aquella 
droga era capaz de hacer. Pero afortunadamente el niño de sus entrañas sólo tenía focomelia en una pierna. Le faltaba una pierna pero le sobraban ganas, y le sobran todavía, y fruto de aquella lucha ha sido un libro que sueña publicar: "Hijos de la talidomida", un testimonio desgarrador de luchas y sueños y tragedias y esperanzas y risas de lo humano. Se trata tal vez del trabajo de investigación más completo realizado en España sobre la talidomida. Casado con una bella burgalesa -Esther - y padre de dos niños -Rubén y Oscar - , José, Pepe como lo llaman cariñosamente, es una muestra cabal de que la adversidad está descalificada ante la fortaleza del espíritu.

España fue uno de los países que más sufrió por culpa de la talidomida en Europa. Fueron tres los laboratorios españoles que introdujeron la droga con la anuencia de Chemie-Grünenthal y la permisividad de las autoridades de entonces. Se ha estimado que entre 1960 y 1963 nacieron en España unos 300 bebés malformados por culpa de la talidomida, aunque algunos autores piensan que dicha cifra no refleja la realidad. Las condiciones socioeconómicas y el nivel cultural de un vulgo castizo, muchas veces analfabeto e inclulto, y la desinformación e indiferencia por parte de gobiernos y autoridades sanitarias permitieron la comercialización en España de hasta siete fármacos diferentes de talidomida por parte de tres laboratorios farmacéuticos, como revela un cuadro incluido anteriormente en el presente reportaje. (Ver Nota 11f en el capítulo 10: La droga que invadió el mundo, donde se detallan los fármacos de talidomida que circularon por España).

Nota de Redacción: Para más información sobre José Riquelme y su obra, recomendamos visitar:

www.hijosdelatalidomida.galeon.com

ó también

www.talidomidamaldita.galeon.com. 


\subsubsection{Una crónica murciana...}

Como una forma de ilustrar la situación que se vivió en tierras españolas durante los años 60, Riquelme nos cuenta una sabrosa anécdota que tuvo ocasión de vivir cuando quiso entrevistar a un visitador médico en su ciudad natal... "El visitador médico de Medinsa que en Murcia vendió, distribuyó y representó el preparado Softenón, compuesto de Talidomida, fue el Sr. Nicolás Leal Rodríguez, --que falleció hace 15 años - por cuya venta de cada frasco, obtenía una peseta de comisión. Cuando me dirigí a él para obtener alguna información al respecto, se "pasmó" literalmente, y no quiso hacer ningún tipo de declaraciones, pocos años antes de morir. Aunque algunas conclusiones si pude sacar de aquella conversación telefónica mantenida con él y que más adelante detallo."

En otra sección de su libro, el autor describe aquel diálogo telefónico, que tuvo lugar en Murcia en abril de 1980: "Este señor, a lo largo de toda la conversación telefónica que mantuve con él, únicamente se limitó a mentir, asediar y atemorizarme para inculcarme temor ante el tema. Así transcurrió nuestra conversación telefónica.

- D. Nicolas, ¿Vd. era el representante o visitador médico de Medinsa en Murcia en los años $60 ?$

(Rápidamente y con voz atemorizada como si fuese algo contra él, contestó que "ya no lo soy, porque Medinsa se había disuelto en 1979". Esta afirmación tan rotunda y tajante, era totalmente falsa, puesto que posteriormente a esta conversación con el señor Leal, contacté con estos laboratorios en Madrid y me desmintieron la información. De hecho, hoy día, siguen con su actividad de laboratorio funcionando con total normalidad. 
A la pregunta al señor Leal, de cómo se llamaba o se llamaban los compuestos talidomídicos que distribuyó Medinsa en España, contestó que "solamente fue uno y se llamaba Softenón. Estaba compuesto única y exclusivamente de Talidomida. Exactamente no recuerdo cuando se retiró, pero aproximadamente por el año 1962".

Nuevamente este señor me volvió a faltar a la verdad impunemente, ya que no fue sólo uno el fármaco que circuló por España, sino siete los que circularon alegremente y 4 de ellos, distribuidos precisamente por el laboratorio que él representaba: El SOFTENON comprimidos, NOCTOSEDIV comprimidos, ENTERO-SEDIV comprimidos y ENTERO-SEDIV-SUSPENSION Solución.

Tampoco se ajustó a la realidad en el sentido de que no solamente estaban compuestos de Talidomida.

A continuación le pregunté por los motivos que dieron lugar a la retirada del mercado farmacéutico de la Talidomida, a lo que me respondió "...En Alemania e Inglaterra empezaron a nacer niños malformados a causa de los compuestos que contenía la Talidomida. A raíz de ello, recibimos una orden expresa de los laboratorios Chemie Grünenthal en Stolberg (Alemania), para que todas las existencias de productos que contenían Talidomida, fuesen retiradas, así como todo lo demás estrictamente relacionado y ligado con la Talidomida (papeles, propaganda, folletos, etc.)."

También le pregunté si llegaron los laboratorios en España que él representaba o incluso él mismo, a conocer algún caso producido por la ingestión de la Talidomida, y ante esta cuestión, reaccionó en un tono enfurecido y violento y respondió que "absolutamente ninguno. Es más, yo estuve vendiéndolo aquí en Murcia, y como la comisión que me llevaba era de una peseta por frasco que colocaba, y como se vendia 
muy poco, tuve que dejar de venderlo. Pero oficialmente no se ha solicitado ninguna reclamación por daños y perjuicios".

- ¿O sea, que cada víctima de la Talidomida, valía 1 peseta? ¿Ese era su precio?

No me contestó.

Ante esas afirmaciones tan rotundas, le sugerí y advertí de que podía estar hablando con una persona, que podía estar afectada y ser víctima de la Talidomida. Y rotundamente y muy nervioso y enfurecido me contestó: "jeso es imposible!. Oficialmente no se conocen casos. Además, ha tenido $\mathrm{Vd}$. que esperar 20 años para mover todo esto. Sus padres tenían que haberlo movido nada más nacer".

Más vale tarde que nunca, le contesté e increpé... "Si, pero Usted. para conseguir lo que me figuro querrá conseguir, que será una indemnización, y para afirmar eso, tiene que tener pruebas y se va a tener que gastar un dineral. Tendrá que contratar a un buen abogado. Tendrá que desplazarse a Alemania y el viaje cuesta mucho. Tendrá que meterse en juicios y todos los gastos correrán de su cuenta. Y si luego pierde el juicio..."

Afortunadamente, todas aquellas personas que consideraron haber sido víctimas de la Talidomida, estas coacciones del señor Leal, no se vieron ni se verán nunca realizadas ni consumadas; ya que para tal motivo, el gobierno alemán constituyó la ya aludida Fundación "Hilfswerk Für Behinderte Kinder" (Auxilio a niños impedidos), la cual fue la encargada de indemnizar a todo aquel chico o chica que previamente acreditase haber sido afectado por la tétrica Talidomida.

En síntesis, este fue el contenido de la conversación telefónica que mantuve con este señor. En ella se pone de manifiesto, que constantemente mentía e intentaba a la vez 
atemorizar, en un estado permanente de miedo y nerviosismo; por temor seguramente a que yo iba a tomar alguna represalia contra él. Cosa que ni lo pensé en ningún momento ni hice. Sólo pretendía obtener información.

Aunque otra conclusión que saqué fue, que ese miedo y nerviosismo que mostró durante toda la conversación, intentando atemorizarme y aterrorizarme para que no avanzase en mis investigaciones; seguramente se debía a que pensaba que a él podía salpicarle en algo jurídicamente y a efectos legales.

D. Nicolas Leal Rodríguez, nació en Ciudad Real el 27 de mayo de 1918, y falleció en su casa de Murcia, en la C/ Mariano Vergara, número 6; el 26 de diciembre de 1985, de una Cardiopatía Isquémica. Por tanto, contaba con 67 años cuando murió. Sus restos descansan en el cementerio de Nuestro Padre Jesús de Murcia capital, en la zona 23, fosa número 223."

\subsection{Beatriz de Gran Canaria}

En su libro, José Riquelme nos cuenta historias tan sorprendentes como la de la canaria Beatriz López-Pérez (53), una joven que nació sin brazos ni hombros, pero que consiguió viajar a Estados Unidos para lograr su rehabilitación de forma milagrosa...

"En la Isla de Gran Canaria, Beatriz López nació sin brazos. Los efectos de la Talidomida, también se habían cebado en ella. Sus padres naturales la abandonaron en la Casa Cuna de Las Palmas. Ahora, gracias a la solidaridad, Beatriz ya puede abrazar.

El cariño de Sor Pino hacia Beatriz, se notaba a flor de piel. La llevaba al pueblo de Firgas los fines de semana, hasta que el hermano de esta religiosa, Antonio López y 
su mujer, Salvadora Pérez se convirtieran en los padres adoptivos de la niña. Así se convirtió en la mayor de seis hermanos.

Todo lo que Beatriz podía hacer, lo hacía con los pies. Pero no se resignaba a ello y empezó su cruzada particular. Ella quería ser como los demás, coger un vaso... Iba a todas las ortopédicas que conocía y en todas le decían que para su problema, no había solución. Se trataba de un caso muy difícil ya que era de nacimiento y no por amputación, como ocurría con la mayoría.

Los médicos le aconsejaban resignación. Pero Beatriz nunca desistió. Llamó a todas las puertas habidas y por haber. Escribió a la Reina Sofía. Suplicó ayuda a los políticos, pero todos los intentos fueron en vano. En todos los casos, le decían que su problema se lo podían solucionar en la península. Pero ella no se lo creía y de hecho, los profesionales médicos y ortopédicos no le daban soluciones.

Estuvo durante años buscando una prótesis como la que tiene ahora y todos le aseguraban que era imposible.

Tras encontrarse con la negativa de los gobiernos autonómico y central, Beatriz, pidió ayuda al pueblo canario, sirviéndose de los medios de comunicación locales. La respuesta no se hizo esperar. Periódicos, radio y televisión, lanzaron el mensaje desesperado de una joven que necesitaba treinta y dos millones de pesetas, para conseguir unos brazos. Los canarios se sintieron impresionados por esta muestra de coraje y comenzaron a llegar las primeras ayudas económicas.

En pocos meses, la mágica cifra de treinta y dos millones de pesetas, estaba por completo en el banco. Beatriz había triunfado en el primer reto. Ya tenía el dinero para poder ingresar en el John Hopkins Hospital de Baltimore de EE.UU., el único lugar del mundo que se atrevió a dar alas a los sueños de esta joven. 
Beatriz, a fuerza de no resignarse, había conseguido lo que tanto había anhelado.

Por un lado le daba pena partir hacia Baltimore, pero por otro, tenía mucha ilusión. Ya en Baltimore, tenía momentos de desilusión, porque estaba muy baja de moral, pero no le duraba mucho y rápidamente se volvía a animar.

Cuando llegó al Hospital, el primer paso que dieron los médicos, fue realizarle todo tipo de pruebas médicas, sacando la máxima información posible. Luego comenzaron a calificar y a descalificar sobre lo que iban o no a hacer. Para entonces, ya habían transcurrido 4 meses.

A continuación le sometieron a una terapia intensiva de siete meses y luego, comenzaron la fabricación de la prótesis, -la más compleja del mundo-. Nunca en Baltimore habían hecho una prótesis similar, porque la tuvieron que adaptar al clima canario y a su cuerpo.

La adaptación de la prótesis fue un tanto compleja, ya que la candidata no tenía hombros, y lo que sí tenía era la clavícula de atrás encima de la de delante.

En el Hospital de Baltimore siempre habían realizado prótesis a gente que carecía de extremidades por causa de amputación traumática. Jamás habían puesto manos bioeléctricas en un caso similar al de Beatriz, tratándose de un caso congénito y complicado.

El funcionamiento de su prótesis es, aparentemente, sencillo. Con los hombros, va tocando como unos botoncitos, y ellos van haciendo la rotación, apertura, cierre. Lo demás es estudiar los movimientos de cada persona y copiarlos. Allí se sentaba delante de su psicóloga Branda Almena y se pasaba horas intentando copiar sus movimientos. 
Cuando por fin tuvo ante sí la prótesis, por la que tanto había luchado, sintió una alegría inmensa. Casi no podía creer que el momento había llegado.

Lo que más le impresionó, fue su realismo. Parecían como dos manos de verdad, con sus venas y sus uñas. Ella fue quien escogió el color y la forma de sus manos.

Recibió numerosos regalos en el Hospital. Los médicos, enfermeras, su psicóloga... le regalaron varios anillos y pulseras. Le hicieron mucha ilusión, ya que hasta entonces jamás había podido llevar una joya.

Afortunadamente, ya no tendrá que utilizar tanto los pies, y una de las grandes ventajas que encuentra, es que podrá llevar medias y no tendrá que preocuparse de ponérselas y quitárselas, y podrá presumir más.

"Mi pie izquierdo..." la rehabilitación de Beatriz en el John Hopkins Hospital de Baltimore le permitió adquirir habilidades insospechadas, como la de manipular aparatos eléctricos con los pies. La joven canaria no quiso que su rostro saliera publicado en estas páginas.

En EE.UU. causó sensación y se quedaron alucinados de cómo los manejaba. Le hicieron un vídeo y apareció en tres televisiones, vistiéndose, cambiando a un niño, escribiendo a máquina, cocinando...

No necesitó asistir a ningún colegio especial para aprender a manejar los pies. Sólo necesitó ver e imitar. Por eso pensaron que su mejor terapia para que aprendiera a manejar los brazos, era viendo los movimientos de una persona normal. 
De Baltimore, Beatriz, guarda muy buenos recuerdos. Con todos congenió fenomenalmente. De lo único que se quejaban era de que no paraba de hablar. Le decían que se callase un poquito, y eso que al principio, casi no sabía hablar inglés.

Con todo el mundo se llevó muy bien, pero cuando faltaban sólo seis meses para volver a casa, llegó un joven extremeño de 25 años, Diego Fenia Godoy, al centro médico de Baltimore, con quien compartió una estrecha relación.

Diego había perdido los dos brazos, debido a una descarga eléctrica. Se los tuvieron que amputar a la altura del codo, pero surgieron complicaciones y se los tuvieron que volver a cortar más arriba. Diego necesitaba sus brazos, ya que trabajaba con su padre en el campo. Por ello pidió ayuda a la Junta de Extremadura y se la concedieron.

Para Beatriz, Diego era una persona maravillosa, comprensiva y muy cariñosa. Con él, encontró alguien con quien compartir su especial manera de ver la vida.

La compañía de Diego le supuso un soplo de aire fresco, y el poder estar un poco más cerca de España.

Aunque le costaba decir que estaba enamorada tremendamente de él, sí reconocía que era pronto para hablar de amor. Pero también afirmaba que era un amigo muy especial y alguien con quien compartió cosas exclusivas.

Hicieron excursiones por sitios muy bonitos, se preparaban la comida... Juntos encontraron algo que ninguno olvidará: el ser útil. Ella le intentaba enseñar a manejar los pies para abrir una puerta, beber, escribir. Diego alucinaba mucho con los pies". 


\subsection{Un alcalde en Teruel}

José Marqués Hernández, de Teruel (España), es otra víctima de la talidomida que ha sabido labrarse un futuro; es una de las pocas víctimas españolas que logró ser indemnizada por el fabricante del Softenon que tomó su madre y que le hizo venir al mundo sin brazos. Su caso, emblemático por cierto, se hizo conocido por su incursión en la política: fue alcalde del pequeño pueblo de Villastar, en Teruel, durante siete años (1983 - 1990). Además es un gran aficionado a la pintura (pinta al óleo) y gusta mucho de la arquitectura. Don José todavía conserva como un tesoro el viejo frasco de softenon con algunas de sus píldoras, ya amarillentadas por el tiempo, que tomó su madre para paliar las molestias del embarazo.

José Marqués mostrando la cajita del fármaco Softenon que tomó su madre, causa de su malformación congénita.

Una rareza farmacéutica, esta cajita de Softenon con sus píldoras amarillentas significa mucho para su dueño, José Marqués.

\subsection{La vida de Tom es un arte}

La talidomida aguzó la creatividad de quienes la sufrieron, al menos eso es lo que parece demostrar Tom Yendell (54), una de las tantas víctimas de la talidomida en Gran Bretaña. Sin brazos pero con un pincel en la boca y una voluntad férrea, Tom se dedica a crear hermosas obras de arte. Nacido en 1962, su madre, una enfermera, ingirió la droga fatídica que le privó de sus miembros superiores. Sin embargo, esto no le ha impedido tener su propia galería de arte en Shelbourne. A pesar de su minusvalía, Tom tiene esposa y dos hijos ya jóvenes y se siente feliz con sus creaciones pictóricas: "Quizá si no hubiera nacido con este talento -dice-, no habría tenido una vida tan maravillosa. He logrado tanto. He influido en otras vidas. Lo que 
importa es la manera con que miras la vida; no importa los pedacitos de anatomía que te falten..."

\subsection{Un chico de pelo rubio y famoso}

En Suecia, un chiquillo rubio y de ojos azules fue un día el niño mimado de los periódicos suecos. Y no era para menos. Este fue el país escandinavo más afectado por la talidomida en los años 60: 107 víctimas, contra 17 en Noruega, 8 en Finlandia y 20 en Dinamarca. Pero para Rolf A. Lager (55) esta es historia pasada. Hoy, a sus 35 años, Lager es un experto del comportamiento y las reacciones humanas y trabaja en sistemas y economía en Estocolmo, la capital sueca, conocida como la "Venecia del Norte". Su pelo rubio hizo que le apodaran "Putte" o "cerveza dorada" en su lengua materna. En 1966 su rostro era el más fotografiado y conocido en los medios impresos de su país. Pero él no se siente "diferente": Rolf tiene su particular filosofía de la vida, pese a que la talidomida le afectó brazos y piernas y se vio obligado a utilizar prótesis. Su pensamiento sobre la maldición que afligió a millares de bebés refleja su edificante forma de ver la vida: "Tendemos en llamar a esos niños, con cierto cinismo, la segunda generación. Podríamos pensar que esta cosa del pasado desarrolló... algo increíble... Y ahora estamos viendo a nuevos bebés de la talidomida que nacen otra vez. ¡La comunidad mundial no aprendió una cosa! -Puntualiza cuando se refiere a los niños malformados nacidos recientemente en Sudamérica.

"Para mí es completamente ridículo, es que realmente no lo significan -señala Rolf cuando se refiere a la vergüenza que asume la sociedad, más aún cuando son los propios miedos de las víctimas de la talidomida-; la cara humana puede estar revelando curiosidad, miedo, repugnancia compasión... ipuedo decir lo que están pensando! -y añade - Cuando un hombre está sorprendido, él no puede guardar su cara. Cuando lo intenta, el efecto puede ser más fuerte; cuando satisfago mi 
curiosidad al ver una malformación, ellos reaccionarán rápidamente; es cuestión de mirar fijamente, sinceramente..."

Suecia fue el primer país donde los padres de las víctimas decidieron entablar demanda judicial contra la compañía que vendió la droga de la talidomida. Rolf fue uno de los querellantes en el primer proceso jurídico en el mundo contra un fabricante de la talidomida en 1965. El proceso entre Astra (una firma sueca autorizada para producir y vender la talidomida de Chemie-Grünenthal en Escandinavia) y los afectados se prolongó por cuatro años, hasta que un tribunal de Estocolmo obligó al fabricante a indemnizar a las víctimas suecas del Neurosedyn.

\section{6. ¡Qué no hacen los japoneses!}

Pocos años antes de su muerte, el Dr. Widukin Lenz, el especialista que dio la voz de alerta sobre los peligros de la talidomida, realizó una visita al Japón acompañado de su esposa, donde pudo constatar el nivel de organización a que han llegado las víctimas de esta droga en dicho país -aproximadamente unas 300-, que han formado su propia fundación, "Ishizue" (58), uno de cuyos miembros principales es su fundador, Tsugumichi Sato, una víctima de la talidomida que ha dedicado su vida para divulgar los efectos de la talidomida y unir a sus paisanos afectados.

Un grupo de víctimas japonesas de la talidomida posa en Nagano, durante los Juegos Olímpicos de Invierno que se celebraron en dicha ciudad en 1998. Aquí están, de izquierda a derecha, Kentaro Katoh, Kaoru Naguchi, Keiko Matsumura, Kaoru Omi, Kazuhiro Yamamoto, Yoshiro Hoshi y Tsugumichi Sato, este último es el fundador de la sociedad Ishizue, que reúne a todos los afectados por la droga en dicho país.

En el Japón, los efectos de la talidomida fueron devastadores debido a que fue vendida en grandes cantidades, llegando hasta los rincones más apartados del país, a 
lugares donde la población desconocía el inglés o el alemán, las lenguas en que estaban escritas las etiquetas de los fármacos con talidomida, y menos conocían la grafía latina. La ignorancia de la lengua y la poca información sobre los peligros de la talidomida permitió que el laboratorio japonés Dai Nippón (59), autorizado por Chemie-Grünenthal, y contando con la anuencia remunerativa del gobierno japonés, pudiera introducir entre 1958 y 1963 más de diez fármacos con el letal ingrediente en las farmacias. (Nota 13) De todos los niños nacidos con malformaciones congénitas, sólo sobrevivió el 20\%. El 80 por ciento de los bebés afectados fallecieron en el primer año de vida, lo que representó un récord en la cantidad de muertes por esta causa en comparación con el porcentaje de otros países (un 40\%). El escándalo provocado por la talidomida fue finalmente llevado a los tribunales de la isla de Okinawa, cuyos jueces obligaron al distribuidor Dai Nippon a idemnizar a las víctimas de la droga.

La sociedad "Ishizue", fundada por Tsugumichi Sato en 1974, es un centro nacional para todas las víctimas de la talidomida japonesas. Aquí sus integrantes pueden encontrar asesoramiento legal, apoyo psicológico, tratamiento médico, hacen excursiones y participan en diferentes actividades culturales y deportivas. Esta asociación se ha convertido en un ejemplo de cómo la gente puede juntarse para ayudarse a paliar las carencias físicas y emocionales provocadas por uno de los mayores desastres farmacológicos de la historia. (60)

Nota 13: Como se habrá visto en la lista del TVAC, Dai Nippon introdujo en el Japón los siguientes medicamentos: Bonbrain, Glutanon, Isomin, NeoNibrol (también: New Nibrol), Nerufatin, Proban-M, Sanodormin, Shin-Naito-S, Shin Nibrol, Sleepan. Volver al párrafo Volver al principio del artículo $\quad$ Volver al principio 


\subsection{Con los pies canta mi guitarra...}

Es tal vez uno de los talidomídicos con mayor éxito en el mundo de la música latina. El mundo lo recuerda por ser uno de los artistas que le cantaron al Papa Juan Pablo II durante una gira de éste por los Estados Unidos en 1987. Tony nació sin brazos debido a los estragos de un medicamento recetado por orden médica a su madre durante el embarazo. La talidomida, supuestamente, era un fármaco que debía calmar los efectos de las náuseas propias del primer semestre de la gestación. Sin embargo, sus efectos dejaron un terrible saldo, miles de niños nacieron con deformidades, sin brazos, sin pies o faltándole ambos.

Cuando niño, Tony veía a su papá tocar la guitarra y sintió el gran deseo de poderla tocar también, hasta que un día su papá puso la guitarra en el suelo. "Tony -dijo-, anda a lavarte los pies." Se los lavó y se sentó a tocar la guitarra por primera vez. Nunca dejó que su condición física le desanimara, y con mucho esfuerzo y práctica, aprendió a tocarla magistralmente con los dedos de sus pies.

Tony empezó tocando en misa y en conferencias, hasta que lo vio alguien que trabajaba en la organización de las actividades para la visita del Papa a Los Ángeles en 1987. Tony fue seleccionado para cantarle al Papa y a los jóvenes, y allí ocurrió el famoso encuentro, cuando el pontífice emocionado por la belleza de la canción que Tony le estaba cantando, se bajó del estrado y lo abrazó.

Desde ese momento no ha descansado, ha viajado a través de los Estados Unidos y a más de 30 países alrededor del mundo, compartiendo su música y hermoso testimonio de vida y fe. Actualmente reside en Branson, Missouri, con su esposa e hijo, donde también tiene una banda. 


\section{Epílogo I: Desde Murcia, habla José Riquelme}

Testimonio II - martes, 28 de octubre de 2002

11:03:13 am

"Al igual que otras muchas personas, nunca pude demostrar ser víctima de la Talidomida. A pesar de que mis secuelas de focomelia y mi fecha de nacimiento, coincidían plenamente con las fechas "legales" de la puesta en circulación de la maldita Talidomida.

Y todo porque quien decidía si una persona era víctima o no de ella, era una comisión médica, pagada por el gobierno alemán y emitía su veredicto y diagnóstico, a la sola vista de las secuelas y no en base a ninguna prueba médica ni científica.

Siempre alegaron que la Talidomida afectaba a sus víctimas, en todos los casos bilateralmente, a los 2 y/o 4 miembros (brazos y/o piernas), pero no unilateralmente, como era mi caso, y el de otras víctimas. Es decir a una sola pierna o brazo.

Fruto de ello, y sobre todo por querer conocer la verdadera causa de mi malformación congénita, y por mi curiosidad innata, esta circunstancia me llevó a investigar y recopilar un caudal importante de información. Incluso tuve que sufrir gran cantidad de amenazas y coacciones, como consecuencia de todas estas investigaciones. Resultado de todo fue el escribir el libro "Hijos de la Talidomida".

Con él, aparte de demostrar infinidad de datos y poner al descubierto numerosos testimonios, lo que pretendo es -sin odio ni rencor- contar todos estos aspectos, y que un holocausto de esta magnitud, no se vuelva a repetir. Aunque por el camino que vamos: rehabilitándola, vendiéndose en el mercado negro, haciéndose ensayos clínicos con ella, haciendo pruebas en universidades, administrándola a embarazas 
en la actualidad en las selvas amazónicas de Brasil y Perú... éste no es el mejor camino para que seres indefensos, tengan que soportar de por vida, en contra de su voluntad, unas secuelas producidas por la irresponsabilidad de unos personajillos, por llamarlos de alguna manera. En caso de que no mueran al nacer o terminen suicidándose, con el paso de los años, como ya ocurrió.

Este libro quiere ser un testimonio vivo sobre ello, como fiel reflejo y como ejemplo de los futuros errores que nuestras generaciones venideras deben evitar cometer.

Mi existencia ha sido dura, muy dura y tuve que sufrir y padecer las consecuencias de la amputación de la focomelia congénita, de la pierna derecha, cuando tan sólo contaba con 17 años de edad; al solo objeto de acoplarme mejores prótesis ortopédicas para poder caminar con mayor comodidad de lo que ya lo hacía. Ya que caminar para mí, hasta ese momento, se había convertido en un autentico suplicio, infierno y calvario. Con mi libro, y con mi testimonio, quiero servir de ejemplo y de ayuda para todas aquellas personas que lo puedan necesitar, para superar sus adversidades, y las piedras y obstáculos que puedan encontrarse a lo largo de su existencia.

Y si alguien se siente afligido, triste, apagado o melancólico por este tema, tiene la obligación moral de levantar el ánimo, porque así lo han hecho la mayoría de víctimas de la Talidomida en todo el mundo, asociándose y compartiendo a través de Internet, sus propias experiencias. Y por supuesto, superándose día a día, con mucha imaginación e ingenio todas las trabas que les han impuesto.

Mi libro no ha querido, -hasta ahora- publicarlo ninguna editorial española, aduciendo y alegando, cuando era leído por éstas, que no encajaba dentro de su línea editorial. Otras ni siquiera se han molestado en leerlo ni en contestarme. 
No obstante, sigo en mi empeño, y si en vida no consigo publicarlo, dejaré esta labor encomendada a mis hijos, como testamento, para que intenten poner al descubierto y demostrar todo aquello que yo no pude.

De todas formas, aviso de que soy muy constante y perseverante, y la mayoría de cosas que me he propuesto en la vida, las he llevado a feliz término, y a buen puerto. Por lo que esto puede ser un aviso a navegantes.

A pesar de los bajones lógicos de moral, que a veces me rondan la cabeza, pienso que la vida es bella, y merece la pena vivirla y luchar por ello, y por lo que tienes alrededor.

Tengo una familia maravillosa: una esposa excelente, 2 hijos preciosos y un buen trabajo.

Aún así, en plena etapa de la pubertad, alguna lágrima que otra brotó de mis ojos; y por aquella época de adolescente, rebelde y juvenil -difícil etapa por cierto de por sí-; me preguntaba con frecuencia, el porqué me tuvo que tocar precisamente a mí.

La Talidomida fue el ejemplo de la irresponsabilidad humana, pero a la vez, debe servir de esperanza para todas aquellas personas de bien y buen corazón."

\section{Epílogo II: La "talidomida" un riesgo monstruoso}

(Un juicio en Lieja)

"5 de noviembre (1962) - Ampliamente utilizada como sedante, la talidomida origina terribles malformaciones fetales, cuando la madre consume la droga durante los primeros meses del embarazo. Así lo han comprobado recientes investigaciones realizadas cuando en todo el mundo, pero especialmente en Europa Central, se 
habían registrado ya más de dos mil casos de niños nacidos con malformaciones irreversibles.

Caso Polémico. Jean Noel Vandeput y su esposa Suzanne Vandeput-Coipel, los padres belgas la niña Corinne, se sentaron en el banquillo de los acusados en Lieja por haber envenenado a su hija que había nacido deforme. Pero después de un histórico proceso que conmovió a toda Europa, fueron finalmente absueltos merced a un controvertido fallo, después de que los padres admitieron haber matado a la niña "por amor..."

Corinne, hija de Suzanne Coipel, nació sin brazos; su madre, que tiene 24 años, había usado durante su embarazo un tranquilizante llamado Softenon, derivado de la talidomida. Cuando los médicos le dijeron que su hija sólo tenía una posibilidad entre diez de sobrevivir, Suzanne -con la ayuda de su madre, de su marido, de su hermana y del doctor Jaques Casters - preparó un biberón en el cual, diluido en agua y miel había un poderoso veneno, prescrito por el doctor Casters. Se lo dio a beber a la recién nacida, que a la mañana siguiente estaba muerta.

El caso fue llevado ante los tribunales de la ciudad belga de Lieja, que acaba de dar a conocer un veredicto histórico: todos los acusados han sido absueltos. El fiscal había sostenido: "En nombre de todos los padres que aceptan con amor a sus hijos deformes, yo pido una condena." Pero para el jurado no se trataba de juzgar el principio de la eutanasia, sino un caso individual bien diferenciado. Cuando se dio a conocer la sentencia absolutoria, el público presente en la sala prorrumpió en aplausos. Los responsables de la defensa, por su parte, dieron a conocer una declaración. "Quienes deberían ser juzgados son quienes pusieron en circulación la talidomida, culpables de un delito contra la humanidad." Hoy lo comentan todos los periódicos."

Noticia extraída de "Crónica del Siglo XX" - Plaza \& Janes Editores S.A., 1986. 


\section{Epílogo III: Noticia de última hora... ¿Se retracta la doctora Vásquez?}

De pura curiosidad entramos en el portal de discusión Essentialdrugs (e-farmacos) y nos encontramos con esta carta fechada el 09 de septiembre de 2002, escrita por la jefa del CENAFIM, la Químico Farmacéutica Susana Vásquez, y dirigida a unos "amigos", -en realidad no sabemos de qué "amigos" se trata pero eso no viene al casoen la que su autora parece "retractarse" de sus afirmaciones mencionadas en otra carta suya que enviara, en mayo pasado, al autor de este reportaje, pero a través también de este mismo portal de discusión. En dicha misiva, la especialista (i?) anuncia que la talidomida está registrada en el Perú recién desde el mes de junio del presente año, después de haberlo negado públicamente, con el siguiente texto:

Subject: [e-farmacos] Talidomida (cont.)

From: "Vasquez, Susana" grojas28@hotmail.com

Date: Mon, 9 Sep 2002 18:05:01 -0400 (EDT)

Amigos,

El principio activo talidomida se encuentra registrado en el Perú desde Junio del presente año (2002), como tabletas recubiertas de $100 \mathrm{mg}$ con el nombre comercial de INMUNOPRIN, fabricado por Lab. Monte Verde S.A. de Argentina.

No se tiene conocimiento de registros anteriores al informado y sobre RAM relacionadas con la utilización de este principio activo.

Saludos,

Susana Vasquez

CENAFIM - DIGEMID

(Perú) 
¿Casualidad? Parece que sí, parece que no. Tal contradicción nos hace preguntarnos, entonces... ¿La doctora Vásquez no habrá hecho esta "rectificación" a raíz de las cartas que el autor del presente trabajo investigativo intercambió en su oportunidad con el CENAFIM? ¿No será que al ver su nombre y el de su institución caer en el ridículo, en una postura tan incómoda por culpa de unas afirmaciones suyas, ella habría optado por remitir este mensaje tan lamentable a un destinatario anónimo y, para colmo, público, a través de un foro de discusión de prestigio como lo es Essentialdrugs.org? Sin duda una actitud que parece pintarla de cuerpo entero. ¿En dónde queda, entonces, esta "alta funcionaria" que prefiere escribir a un anónimo antes que a quien ahora escribe y que con tan buena fe quiso intercambiar conocimientos con quien consideraba una experta en su campo, una persona de quien hubiera sido gratificante poder aprender algo bueno? Mejor ni decirlo. Cuando la autora de la misiva dice que... "El principio activo talidomida se encuentra registrado en el Perú desde Junio del presente año (2002)" (Nota 14), está dando pie a la suspicacia... - ¿Por qué precisamente ahora, en este año, y al mes de nuestra primera comunicación (mayo - junio), a esta persona se le ocurre decir que la talidomida recién se encuentra registrada en el Perú, cuando pudo haberlo estado desde mucho tiempo atrás, ya que se trata de una sustancia química conocida como altamente teratógena, utilizada desde hace décadas y con unos antecedentes nada envidiables? -iJusto cuando quien escribe les había mencionado la talidomida, a ellos se les ocurre "registrar" al mes siguiente un principio activo "inexistente"!- ¿Una casualidad o una coincidencia... o ambas? Pero la cosa empeora cuando a renglón seguido ella afirma que: "No se tiene conocimiento de registros anteriores al informado y sobre RAM relacionadas con la utilización de este principio activo." (Ver Ref. 66) Es decir, luego de negar que este principio activo estuviera registrado en el Perú... vuelve a escribir, pero a otro destinatario, para (i?) decir que la bendita sustancia sí se encuentra registrada en el Perú a partir de tal fecha y después... (¿?) dice que no se tiene conocimiento de su uso previo a dicho registro (i?) Entonces... 
¿estamos ante un embrollo lingüístico o ante una contradicción o ante una negativa de la realidad -o mentira, que eso es lo que parece, y no es la primera- remitida en aquella absurda carta fechada el 10 de mayo del presente año, como se puede apreciar al comienzo de este trabajo, y que después ha pretendido desmentir. En este contexto, toda excusa o disculpa está fuera de lugar... nada justifica la desinformación, la "amnesia" o el limbo en el que parece vivir el CENAFIM / DIGEMID, que le ha cerrado las puertas a su propia historia, a la historia sanitaria reciente del Perú, más todavía, a nuestra frustrante historia farmacológica. Que después no se diga que aquí se ha levantado falso testimonio o cosas por el estilo. Por algo se ha dicho que "por la boca muere el pez..." Que juzgue el lector.

Nota 14: Ver para más detalles sobre este punto, en el capítulo 5. "La talidomida en el Perú", el epígrafe 5.2. ¿Quién explica este desaguisado?

Nota de Redacción: A propósito, no se ha encontrado en la web ninguna referencia al aludido Inmunoprin, ni mucho menos de unos Laboratorios Monte Verde S.A. de Buenos Aires, Argentina. Al escribir en el buscador "Google" la palabra "inmunoprin", el buscador remite al navegante a la web de essentialdrugs.org, por única referencia.

\section{Para saber más...}

FDA gives restricted approval to thalidomide (en inglés) http://www.cnn.com/HEALTH/9807/16/thalidomide/

Comunicaciones - DIGEMID (Fármacos)

http:/ / lanic.utexas.edu/project/farmacos/992ind03.htm 
Comunicaciones - DIGEMID (Fármacos)

http://lanic.utexas.edu/project/farmacos/002ind04.htm

Los fármacos de "estilo de vida", los nuevos superventas

http://www.readysoft.es/pm-farma/edicelec/num42/life.htm

Thalidomide Production - Volumes Grow by the day (en inglés)

http://www.thalidomide.org/FfdN/N-fabrik/thatillv.html

Talidomida o ciencia macabra

http://www.oei.org.co/sii/entrega14/art08.htm

Web de Thalidomide org (sueco - inglés)

http://www.thalidomide.org

The History of thalidomide (En inglés)

http://www.rlc.dcccd.edu/MATHSCI/reynolds/thalidomide/history/history.html

Phocomelia - Drugs in Pregnancy (en inglés)

http://www.health.auckland.ac.nz/courses/Pharmcol722/Drugs_in_pregnancy/ drugs_in_pregnancy.htm

Talidomida: Una nueva oportunidad (pdf)

http:// www.imbiomed.com.mx/HG/Hgv63n3/Hg003-05.pdf

Carta de aprobación de la talidomida remitida por la FDA

http://www.fda.gov/cder/foi/appletter/1998/20785ltr.pdf 


\section{Apéndice: Lo que dice el fabricante (Chemie-Grünenthal)}

\subsection{Talidomida 1957 (I)}

"La talidomida y la marca registrada 'Contergan' ${ }^{\circledR}$ son sinónimos de una catástrofe medicamentosa. Con fecha $1^{\circ}$ de octubre de 1957, Grünenthal inició la comercialización del somnífero 'Contergan' ${ }^{\circledR}$. En el lapso comprendido entre esta fecha y 1962 nacieron miles de niños, cuyas madres habían tomado talidomida durante los primeros meses del embarazo, con graves disminuciones físicas.

Como consecuencia de esta catástrofe se aprobó la actual ley de medicamentos. Si bien el somnífero 'Contergan'® ya no existe, la talidomida es -con sus características especiales- muy importante en el área de inmunología (por ejemplo en el tratamiento de la lepra) como lo reportan investigaciones independientes a nivel mundial. En algunos países se han desarrollado procedimientos que garantizan la información al paciente e inhiben un uso inadecuado, a fin de lograr mayor seguridad en la administración.

Grünenthal y los asociados de la licencia de 'Contergan' ${ }^{\circledR}$ fueron responsables de la comercialización en los años 60. Hace más de 20 años cesó la protección de patentes de talidomida. Hoy en día es fabricada en por lo menos seis países, por empresas con las cuales Grünenthal no está en contacto."

\subsection{La talidomida 1957 (II)}

"Desde 1957 hasta finales de 1961 existieron una serie de preparados en el mercado que contenían la sustancia activa talidomida. Cuando en noviembre de 1961 se hizo patente que la ingerencia de talidomida por mujeres embarazadas conducía a deformaciones graves en los niños, se introdujeron profundas modificaciones en la regulación legal de productos farmacéuticos. 
Hoy día la talidomida es de nuevo un componente de productos farmacéuticos.

1. ¿La talidomida hoy día es el mismo medicamento que hace 40 años?

El somnífero Contergan (así fue la marca alemana) se introdujo en el mercado en 1957, después de unas investigaciones previas que, desde el punto de vista actual, no eran suficientemente completas, pero que, sin embargo, correspondían al estándar en uso. Particularmente funesta fue la, aparente, carencia de toxicidad. Dado que apenas se presentaron manifestaciones de toxicidad en los animales de ensayo ni en las personas investigadas, se creyeron como imposibles daños tóxicos crónicos o incluso daños en el embrión, si es que se llegó a reflexionar sobre efectos perniciosos en el embrión. El año 1957 coincide con una época, en la que las investigaciones del influjo de productos químicos exógenos sobre el desarrollo del embrión se las consideraba más desde un punto de vista académico que desde el ángulo visual de una comprobación de la seguridad de los productos industriales.

Las consecuencias catastróficas de esa ingenuidad son bien conocidas. Con la superación, difícil desde el punto de vista social, de los daños desatados por la talidomida, entraron todas las ramas de la Ciencia y del Derecho en un nuevo período de auge. Hoy día, 40 años más tarde, disponemos de una ley compleja sobre productos farmacéuticos que, juntamente con las líneas directrices de renombre internacional, deberán incrementar la seguridad en el desarrollo y en la comercialización de los medicamentos. Dado que los métodos de investigación respecto a efectos no deseados, tanto para el tiempo del desarrollo de los productos medicinales, como para el tiempo de su utilización clínica, se han hecho notablemente más eficientes, se puede ciertamente afirmar que los riesgos desconocidos o imprevistos en la introducción de nuevas sustancias activas han decaído notablemente. 
La Food and Drug Administration (FDA) (Administración sobre Alimentos y Productos Farmacéuticos) norteamericana se ha convertido en una destacada Autoridad de Vigilancia en todo el mundo para productos farmacéuticos. En los comienzos de este desarrollo se encontraba también la talidomida. En USA nunca fue autorizada la talidomida como somnífero. Mientras los colaboradores responsables de la FDA comprobaban los informes sobre las neuropatías (daños en los nervios), que aparecían en Europa en relación con la ingerencia prolongada de talidomida, el Dr. W. Lenz de Hamburgo (más tarde profesor en Münster) y el Dr. W. Mc Bride de Sydney descubrían, independientemente el uno del otro, la conexión entre la talidomida y las deformaciones en los recién nacidos. Los norteamericanos se sienten muy orgullosos de que la talidomida nunca haya sido autorizada en su país.

En 1998 la FDA autorizó el uso de la talidomida para una condición inmunológica que ocurre en ciertos pacientes con lepra. Se trata de la misma molécula, pero en otro medicamento diferente. Debido a las intensas investigaciones en todo el mundo en los últimos 35 años, se ha desplazado hacia el campo visual otra cara diferente de la talidomida. Por supuesto que hoy día se sabe mucho más sobre los riesgos para los embriones y sobre el riesgo de neuropatía. Además se ha puesto de manifiesto que enfermedades inmunológicas graves pueden ser tratadas con ayuda de la talidomida. Una utilidad creciente, para el mismo riesgo mantenido, ha llevado a una revalorización de la relación riesgo/utilidad.

A pesar de que el fabricante norteamericano de la talidomida la hizo proteger con la marca registrada "SynovirTM", la FDA insiste expresamente en la denominación del medicamento más cerca al nombre de la sustancia "ThalomideTM". Esto pone en claro cómo un medicamento representa la combinación de química y información.

La molécula de talidomida no ha sido cambiada desde 1957. Medicamentos con la sustancia activa talidomida tienen hoy día en común con el somnífero "Contergan" 
las propiedades farmacológicas, incluidos los riesgos, pero no los campos de aplicación, la dosificación, ni tampoco las condiciones legales de su utilización. Se trata por lo tanto de un medicamento totalmente nuevo.

2. ¿Se necesitó realmente la talidomida hace 40 años? ¿La necesitamos nosotros hoy día?

En 1957 se contempló la introducción del "Contergan" como un incremento en la seguridad para los pacientes. Los somníferos entonces en uso, los barbitúricos, creaban dependencia y eran en muchos casos, intencionadamente o inintencionadamente, letales por sobredosis. De aquí que los médicos consideraran a la talidomida como un enriquecimiento de su instrumental.

Hoy día, el somnífero "Contergan" ya no se utiliza. Los barbitúricos hace tiempo que han sido desplazados por otras sustancias más seguras. Si se tratara solamente del efecto inductor de sueño, la talidomida podría ser prohibida sencillamente en todo el mundo.

Se ha puesto de manifiesto que, independientemente del efecto como somnífero, determinadas enfermedades inmunológicas pueden ser tratadas mejor con talidomida que con corticoesteroides. Los corticoesteroides son medios eficaces para reprimir las reacciones de inflamación. La talidomida actúa en algunas situaciones en las que el efecto de los corticoides no es suficiente, o en las que, durante el tiempo de su aplicación, la dosificación necesaria produce fuertes efectos secundarios. Se trata de manifestaciones en parte desfiguradoras, en parte inhibidoras de funciones y en parte también de manifestaciones mediatamente amenazadoras de la vida. De aquí resulta que hoy día se utilizan de nuevo medicamentos con la sustancia activa talidomida. 
3. ¿Puede un medicamento volverse más seguro con el transcurso del tiempo?

La catástrofe del "Contergan" se transformó en el acontecimiento de más graves consecuencias en el desarrollo de sustancias activas farmacéuticas, debido a la ignorancia y tal vez también a defecto de atención. Esta catástrofe ilustra sobre todo la importancia del "Post Marketing Surveillance". Ya que incluso hoy día se pueden reconocer, mediante experimentos con animales, muchos de los efectos deseados de una sustancia, pero no todos. Frente a esto podemos partir del hecho de que, entretanto, los efectos no deseados de la talidomida han sido plenamente conocidos y descritos. Aún cuando alguno de los efectos atribuidos a ella puedan ser controvertidos, se puede decir que la aplicación de la talidomida, después de una completa aclaración, con el consentimiento del paciente, así como tras una observación cuidadosa por el médico, se ha hecho más segura. En favor de esto, y no en último término, habla el hecho de que fabricantes y autoridades, independientes unos de otros, en Alemania, el Reino Unido, Francia y los Estados Unidos de América, han elaborado y complementado medidas casi idénticas de esclarecimiento y de seguridad.

4. ¿Se han extraído consecuencias suficientes de la tragedia de la talidomida?

En los países industrializados se han extraído consecuencias de las experiencias de finales de los años 50 y comienzos de los años 60. Esto lo prueba la autorización por primera vez de la talidomida en USA. Dado que la protección por patente entretanto ha vencido, existen hoy día otros nuevos fabricantes en el mundo. No todos los fabricantes de entre ellos controlan la venta y el empleo de cada envase, tal como es el caso en los países nombrados. El control cuidadoso y la documentación de cada uno de los tratamientos debería imponerse en todo el mundo. Grünenthal ha elaborado una documentación modelo para este modo de proceder y está dispuesta a suministrar la información a los interesados sobre el tratamiento con talidomida. 
5. ¿Qué responsabilidad asume Grünenthal en 1998 en el empleo clínico de la talidomida?

Mientras que la sustancia activa estaba protegida por patente, la responsabilidad para la comercialización recaía sólo en Grünenthal y en sus licenciatarios. Esta situación ha cambiado en los años 70. Después de la suspensión de la protección por patente, la talidomida puede ser fabricada por cualquier empresa adecuadamente equipada. Las normas de calidad y el grado de vigilancia oficial son, sin embargo, diferentes de un país a otro. ¿Tiene que rendir cuentas hoy día Grünenthal de algo que una firma en Brasil o en China emprenda con la talidomida? No deseamos contestar a esa pregunta con un rotundo "no". Por supuesto que Grünenthal fue la primera empresa que ha puesto en el mercado la talidomina y ha procurado su extensión como somnífero en todo el mundo. Grünenthal puso también en los años 60 la talidomida a disposición para cualquier comprobación clínica, con cuyo medio ha sido demostrada la eficacia en las enfermedades inmunológicas, en este caso la reacción de la lepra, con una entrega decisiva de la Organización Mundial de la Salud (WHO - OMS). Talidomida constituye hasta hoy un tema que Grünenthal toma muy en serio. Grünenthal se enfrenta a la responsabilidad, en el sentido de que, de una forma irrevocable y clara, ha separado su trato con la talidomida de los negocios comerciales normales. La talidomida no se ofrece activa, sino solamente en base a una demanda de información justificada. Esta entrega no tiene lugar sin análisis previo, sino después de una comprobación de la institución solicitante y de la indicación a ser tratada con el preparado. La cantidad entregada se registra minuciosamente. Este servicio es gratuito para el utilizador. Está vinculado, sin embargo, a la utilización de la documentación concomitante, que garantiza así la seguridad del medicamento."

Fuente: Chemie-Grünenthal (37a-37b). 


\section{Bibliografía}

(1a) Testimonio de Randy Warren

http:/ / db2.doyma.es/cgi-

bin/wdbcgi.exe/doyma/ pescepticemia.plantilla?pident=219

(1b) Fármacos - información sobre talidomida en Perú. Respuesta de la doctora Susana Vásquez (Perú)

http:/ / essentialdrugs.org/efarmacos/hma/e-farmacos.200205/msg00017.php

(1c) Carta del autor del presente reportaje solicitando información periodística sobre la talidomida en el Perú dirigida a e-farmacos http:/ / essentialdrugs.org/efarmacos/hma/e-farmacos.200205/msg00014.php

(2) Wilhem Kunz

http://www.tierversuchsgegner.org/Tierversuche/contergan.html

(3) Chemie-Grünenthal

http://www.grunenthal.com/wwwgrt/

template/spa/company/company.jhtml?ElementId=/wwwgrt/content/company/x $\mathrm{ml} / \mathrm{spa} /$ grt_default.xml

(4) Contergan

http://www.tierversuchsgegner.org/Tierversuche/contergan.html

(5) "March 3, 1999: Pharmacological Hades"

http:/ / www.sunnerdahl.org/m/hades.html 
(6) Doctor Widukin Lenz

http:// www.thalidomide.org/FfdN/Japan/japdef2.html

(7) Universidad de Hamburgo

http://www.uni-hamburg.de/index_e.html

(8) Astra - Suecia

http://www.astra.com

(9) Neurosedyn

http://www.vipeholm.lund.se/biblioteket/Projekt_och_Temaarbeten/katastrofer/E levarbeten/neurosedyn.htm

(10) Distillers Company -- Distaval

http:/ / society.guardian.co.uk/charity/story/0,7834,508944,00.html

(11) "Malformations Multiplying"

http:/ / earthsave.bc.ca/animalvoices/thalido.htm

(12) Revista LIFE en Español. Vol. 20, número 6, 17 de septiembre de 1962

(13) TVAC, siglas en inglés de "Thalidomide Victims Association of Canada" http:/ / www.thalidomide.ca/

(14) LIFE Magazine (edición en inglés)

http:/ / www.life.com/Life/

(15) Doctora Frances Kelsey

http:/ / www.naesp.org/dsa.htm 
(16) William S. Merrell Company

http://www.ibiblio.org/herbmed/eclectic/ephemera/alkaloids-biographies.html http://www.tierversuchsgegner.org/Tierversuche/contergan.html

(17) A.A.D., más conocida como Food \& Drug Administration FDA (Washington) http://www.fda.gov

(18) Kevadon

http://www.tierversuchsgegner.org/Tierversuche/contergan.html

http://www.alternativedr.com/conditions/ConsDrugs/Thalidomidecd.html

(19) British Medical Journal

http://bmj.com/

(20) ESSALUD (Perú)

http:/ / www.essalud.sld.pe/

(21) Colegio Médico del Perú

http://www.colmedi.org.pe/default.asp

(22) Diario Gestión -- Lima

http://www.gestion.com.pe/

(23) Ministerio de Salud (Perú)

http://www.minsa.gob.pe

(23a) Dirección General de Medicamentos, Insumos y Drogas DIGEMID (Perú) http://www.minsa.gob.pe/digemid/ 
(23b) Centro Nacional de Farmacovigilancia e Información de Medicamentos CENAFIM (Perú)

http://www.minsa.gob.pe/infodigemid/paginas/informacion/cenafim/index7.ht $\mathrm{ml}$

(24) Organización Panamericana de la Salud OPS

http://www.paho.org/default_spa.htm

(25) Boletines DIGEMID - FÁRMACOS

http://lanic.utexas.edu/project/farmacos/992ind03.htm

http:/ / lanic.utexas.edu/project/farmacos/002ind04.htm

(26) OMS (siglas en español de World Health Organization)

http:/ / www.who.int/es/

(27) Thalidomide.org

http://www.thalidomide.org

(28) Yorkshire TV

http:/ / www.yorkshire-television.tv/

(29) "Thalidomide: The Drug that came back"

http:/ / www.greenleft.org.au/back/1996/225/225p26d.htm

(30) Der Standard (Austria)

http://derstandard.at/ 
(30a) Pucallpa, Ucayali (Perú)

(31) "Children born in Brazil"

http://www.thalidomide.org/FfdN/Sydamer/sydart.html

(32) Estudio Latinoamericano Colaborativo de Malformaciones Congénitas ECLAMC http://www.histoemb.fmed.edu.uy/defectos/ECLAMC.htm

(33) Asociación Brasileña de Víctimas de la Talidomida, con siglas en portugués ABPST (Associação Brasileira dos Portadores da Síndrome de Talidomida) http://members.tripod.com/ abpstalidomida/tali1.html

(34) Fundação Ezequiel Dias

http://www.funed.mg.gov.br/

(35) Tortuga Compañía Zootécnica Agraria (Brasil)

http://www.thalidomide.org/FfdN/Sydamer/sydart.html

(36) Gollop

http://www.thalidomide.org/FfdN/Sydamer/SYDAMERI.html

(37a) Chemie-Grünenthal - La talidomida

http://www.grunenthal.com/wwwgrt/template/spa/company/company.jhtml?El ementId=/wwwgrt/content/company/xml/spa/ueber_grt_4b.xml

(37b) Chemie-Grünenthal - La talidomida

http://www.grunenthal.com/wwwgrt/template/spa/

company/company.jhtml?ElementId=/wwwgrt/content/company / $\mathrm{xml} / \mathrm{spa} /$ ueber_grt_4bb.xml\#Anchor-Ist-47857 
(38) El Nuevo Thalomid

http://www.fda.gov/cder/news/thalinfo/thalomid.htm

(39a) Thalomid -- Celgene

http://www.celgene.com/thalomid/index.htm

(39b) La posología del Thalomid (pdf)

http://www.celgene.com/images/pdf/\$FILE/Thalomid_Pl.pdf

(40) Celgene

http://www.celgene.com

(41) La FDA aprobó la talidomida para el tratamiento de la lepra

http://www.healthig.com/lepra/lepra2.html

(42) S.T.E.P.S.

http://www.celgene.com/steps/index.htm

(43) La talidomida: Importante información para el paciente

http://ublib.buffalo.edu/libraries/e-resources/ebooks/records/7178.html

(44) "March of Dimes Birth Foundation" - Talidomida

http://www.nacersano.org/BibliotecadeSalud/informatiuas/talidomida.htm

(44a) "Malformaciones congénitas: talidomida o ciencia macabra"

http://www.oei.org.co/sii/entrega14/art08.htm 
(44b) "Medicamentos y Embarazo"

http://www.easp.es/cadime/monograf\%C3\%ADas/asp/plantmono.asp?Numero= 8

(44c) "Estudio de los miembros"

http://www.canalh.net/webs/sgonzalez002/Anatomia/ESTUDMBS.htm

(45) El Mercado Negro de la Talidomida

http://www.thalidomide.org/FfdN/Svartma/uground.html

(46) "De nuevo, la talidomida..."

http:// buenasnoticias.hypermart.net/saludesp.htm

(47) Boletín AIS Perú \# 1 - 1999

http:// ekeko2.rcp.net.pe/AIS-LAC/AIS\%20PERU/Boletin\%20AIS\%20PERU/

SabiUd1.htm

(48) Delpaciente.com

http://www.delpaciente.com/htm/0347.htm

(49) "Medicamentos de riesgo en el embarazo"

http:// perso.wanadoo.es/mcastrov/seleccionesnoticias/Varios/20001121P\%20!\%2U so $\% 20$ farmacos $\% 20$ en $\% 20$ embarazo.htm

(50) "La talidomida, un fármaco maldito en los años 60, podría frenar el avance de un tipo de cáncer"

http://www.estrelladigital.es/010727/articulos/sociedad_medios/cancer.htm 
(51) "La FDA Protege la Salud Pública; Ocupa Lugar Alto en la Confianza Pública" http://www.fda.gov/opacom/factsheets/justthefacts/1fdasp.html

(52) March of Dimes

http://www.nacersano.org/BibliotecaDeSalud/informatiuas/talidomida.htm

(53) Web alemana sobre Beatriz López-Pérez

http:/ / fingertoes.theyeti.com/Beatriz.html

(54) "Tom en Gran Bretaña ha dedicado su vida al arte"

http://www.thalidomide.org/FfdN/England/yeneng.html

(55) Una de las 100 víctimas de la talidomida en Suecia.

http://www.thalidomide.org/FfdN/Arne/arne.html

(56) Die Contergan-Story

http://www.tierversuchsgegner.org/Tierversuche/contergan.html

(57) "Drogas en embarazo"

http:// cancerteam.tripod.com/poli015.html

(58) Ishizue Foundation

http://www02.so-net.ne.jp/ ishizue/frame.html

(59) Dai Nippon Pharmaceutical Co.

http://www.bioscorpio.com/dai_nippon_pharmaceutical_co.htm

(60) "Struggling to meet individual needs"

http://www.thalidomide.org/FfdN/Japan/japdef2.html 
(61) "Vuelve la talidomida"

http:/ / db2.doyma.es/cgi-bin/wdbcgi.exe/doyma/pescepticemia.plantilla?

pident $=219$

(62) "Malformaciones congénitas: talidomida o ciencia macabra"

http:// www.oei.org.co/sii/entrega14/art08.htm

(63) "¿De la tragedia al triunfo? El regreso de la talidomida"

http://www.drwebsa.com.ar/smiba/med_interna/vol_02/02_04.htm

(64) Dow Chemical Company

http://www.dow.com/Homepage/index.html

(65) Richardson-Merrell

http:/ / www.law.harvard.edu/publications/evidenceiii/cases/richardson.htm

(66) Carta de la doctora Susana Vásquez (CENAFIM) publicada en essentialdrugs (efarmacos) el 9 de septiembre de 2002

http://www.essentialdrugs.org/efarmacos/hma/e-farmacos.200209/msg00014.php

(67) Hilfwerk für Behinderte Kinder, (Auxilio a niños impedidos)

http:/ / www.jura.uni-sb.de/BGBl/TEIL1/1997/19972326.A10.HTML

(68) Web referencial sobre Healing Alternatives, un club de compradores

http:/ / www.library.ucsf.edu/sc/ahp/haf.html

(69) Otro enlace sobre Healing Alternatives Foundation

http://www.aids.org/immunet/atn.nsf/page/a-077-07 
(70) John Hopkins Hospital

http://www.hopkinsmedicine.org/

(71) Web alemana sobre Beatriz López-Pérez

http:/ / fingertoes.theyeti.com/Beatriz.html

(72) Instituto Nacional de Estadísticas e Informática del Perú

http://www.inei.gob.pe 